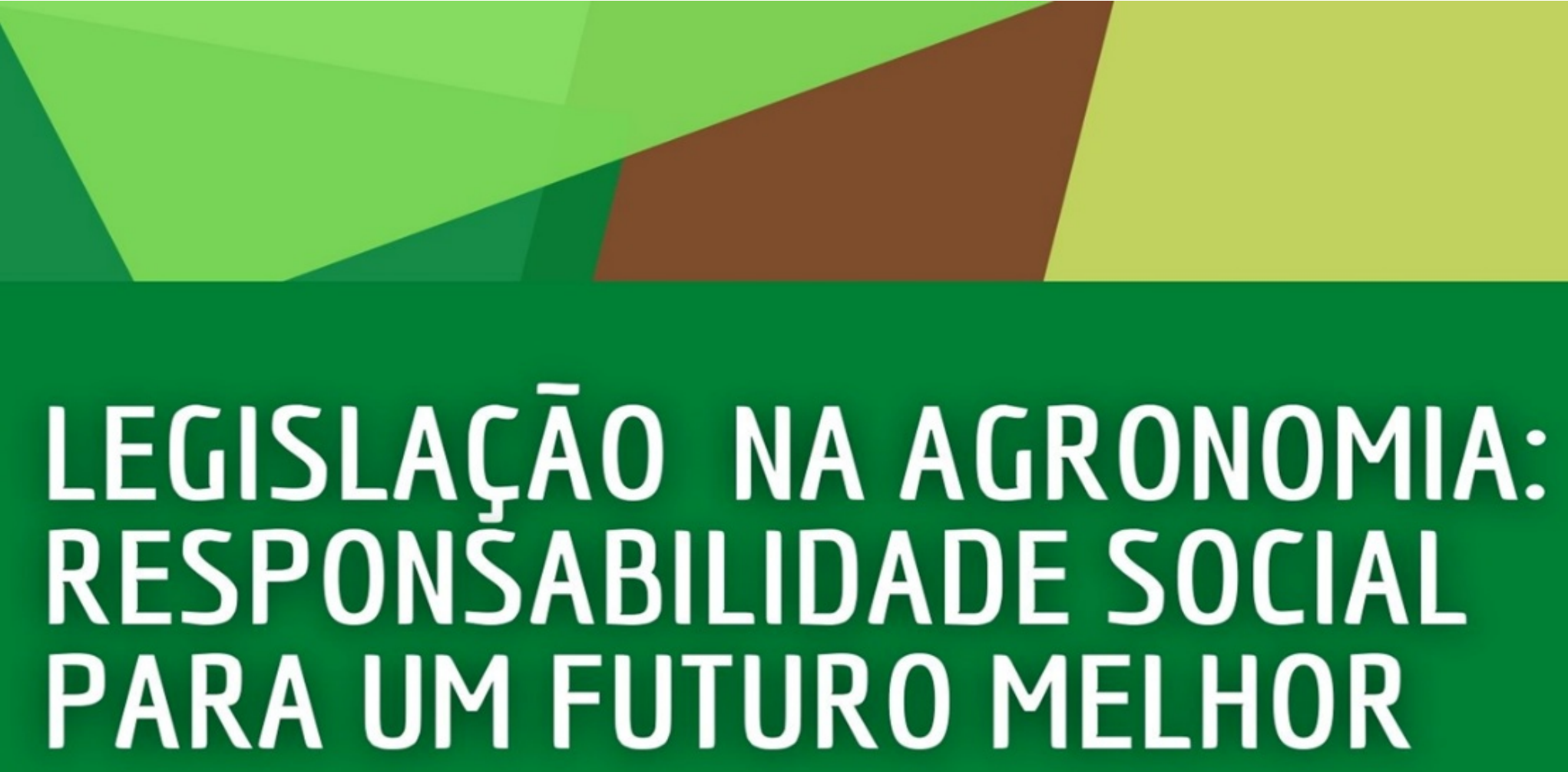

\title{
LEGISLAÇĀO NA AGRONOMIA: RESPONSABILIDADE SOCIAL PARA UM FUTURO MELHOR
}

\section{ORGANIZADORES}

MARIA JOSÉ DE HOLANDA LEITE ANDRÉA DE VASCONCELOS FREITAS PINTO LUIS ALBERTO ROCHA RODRIGUES JUNIOR 


\section{LEGISLAÇĀO NA AGRONOMIA: RESPONSABILIDADE SOCIAL PARA UM FUTURO MELHOR}




\section{ZAMPLLA}

2021 - Editora Amplla

Copyright (C) Editora Amplla

Editor Chefe: Leonardo Pereira Tavares

Design da Capa: Os organizadores

Projeto Gráfico e Diagramação: Higor Costa de Brito

Legislação na Agronomia: responsabilidade social para um futuro melhor está licenciado sob CC BY 4.0 .

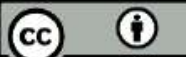

Esta licença exige que as reutilizações deem crédito aos criadores. Ele permite que os reutilizadores distribuam, remixem, adaptem e construam o material em qualquer meio ou formato, mesmo para fins comerciais.

O conteúdo da obra e seus dados em sua forma, correção e confiabilidade são de responsabilidade exclusiva dos autores, não representando a posição oficial da Editora Amplla. É permitido o download da obra e o compartilhamento desde que sejam atribuídos créditos aos autores. Todos os direitos para esta edição foram cedidos à Editora Amplla.

ISBN: 978-65-88332-55-9

DOI: 10.51859/amplla.lar559.1121-0

Editora Amplla

Campina Grande - PB - Brasil contato@ampllaeditora.com.br www.ampllaeditora.com.br 


\section{CONSELHO EDITORIAL}

Andréia Monique Lermen - Universidade Federal do Rio Grande do Sul

Bergson Rodrigo Siqueira de Melo - Universidade Estadual do Ceará

Bruna Beatriz da Rocha - Instituto Federal do Sudeste de Minas Gerais

Caio César Costa Santos - Universidade Federal de Sergipe

Carina Alexandra Rondini - Universidade Estadual Paulista

Carla Caroline Alves Carvalho - Universidade Federal de Campina Grande

Carlos Augusto Trojaner - Prefeitura de Venâncio Aires

Cícero Batista do Nascimento Filho - Universidade

Federal do Ceará

Clécio Danilo Dias da Silva - Universidade Federal do Rio Grande do Norte

Daniela de Freitas Lima - Universidade Federal de Campina Grande

Denise Barguil Nepomuceno - Universidade Federal de Minas Gerais

Dylan Ávila Alves - Instituto Federal Goiano

Edson Lourenço da Silva - Instituto Federal de Educação, Ciência e Tecnologia do Piauí

Elane da Silva Barbosa - Universidade Estadual do Ceará Érica Rios de Carvalho - Universidade Católica do Salvador

Gilberto de Melo Junior - Instituto Federal do Pará

Higor Costa de Brito - Universidade Federal de Campina Grande

Italan Carneiro Bezerra - Instituto Federal da Paraíba

Ivo Batista Conde - Universidade Estadual do Ceará

Jessica Wanderley Souza do Nascimento - Instituto de Especialização do Amazonas

João Henriques de Sousa Júnior - Universidade Federal de Santa Catarina

João Manoel Da Silva - Universidade Federal de Alagoas João Vitor Andrade - Universidade de São Paulo

Joilson Silva de Sousa - Instituto Federal do Rio Grande do Norte

José Cândido Rodrigues Neto - Universidade Estadual da Paraíba

Jose Henrique de Lacerda Furtado - Instituto Federal do Rio de Janeiro

Josenita Luiz da Silva - Faculdade Frassinetti do Recife

Karina de Araújo Dias - SME/Prefeitura Municipal de Florianópolis

Laíze Lantyer Luz - Universidade Católica do Salvador Lindon Johnson Pontes Portela - Universidade Federal do Oeste do Pará

Lucas Capita Quarto - Universidade Federal do Oeste do Pará

Luciana de Jesus Botelho Sodré dos Santos - Universidade Estadual do Maranhão

Luís Paulo Souza e Souza - Universidade Federal do Amazonas

Luiza Catarina Sobreira de Souza - Faculdade de Ciências Humanas do Sertão Central

Manoel Mariano Neto da Silva - Universidade Federal de Campina Grande
Marcelo Alves Pereira Eufrasio - Centro Universitário Unifacisa

Marcelo Williams Oliveira de Souza - Universidade Federal do Pará

Marcus Vinicius Peralva Santos - Universidade Federal da Bahia

Marina Magalhães de Morais - Universidade Federal de Campina Grande

Nadja Maria Mourão - Universidade do Estado de Minas Gerais

Natan Galves Santana - Universidade Paranaense

Nathalia Bezerra da Silva Ferreira - Universidade do Estado do Rio Grande do Norte

Neide Kazue Sakugawa Shinohara - Universidade Federal Rural de Pernambuco

Neudson Johnson Martinho - Faculdade de Medicina da Universidade Federal de Mato Grosso

Patrícia Appelt - Universidade Tecnológica Federal do Paraná

Paulo Henrique Matos de Jesus - Universidade Federal do Maranhão

Rafael Rodrigues Gomides - Faculdade de Quatro Marcos Reângela Cíntia Rodrigues de Oliveira Lima Universidade Federal do Ceará

Rebeca Freitas Ivanicska - Universidade Federal de Lavras

Ricardo Leoni Gonçalves Bastos - Universidade Federal do Ceará

Rodrigo da Rosa Pereira - Universidade Federal do Rio Grande

Sabrynna Brito Oliveira - Universidade Federal de Minas Gerais

Samuel Miranda Mattos - Universidade Estadual do Ceará Shirley Santos Nascimento - Universidade Estadual Do Sudoeste Da Bahia

Silvana Carloto Andres - Universidade Federal de Santa Maria

Silvio de Almeida Junior - Universidade de Franca

Tatiana Paschoalette Rodrigues Bachur - Universidade Estadual do Ceará

Telma Regina Stroparo - Universidade Estadual do Centro-Oeste

Thayla Amorim Santino - Universidade Federal do Rio Grande do Norte

Virgínia Maia de Araújo Oliveira - Instituto Federal da Paraíba

Virginia Tomaz Machado - Faculdade Santa Maria de Cajazeiras

Walmir Fernandes Pereira - Miami University of Science and Technology

Wanessa Dunga de Assis - Universidade Federal de Campina Grande

Wellington Alves Silva - Universidade Estadual de Roraima

Yáscara Maia Araújo de Brito - Universidade Federal de Campina Grande

Yasmin da Silva Santos - Fundação Oswaldo Cruz

Yuciara Barbosa Costa Ferreira - Universidade Federal de Campina Grande 


\section{ZIMAMPLA}

\section{1 - Editora Amplla}

Copyright (C) Editora Amplla

Editor Chefe: Leonardo Pereira Tavares

Design da Capa: Os organizadores

Projeto Gráfico e Diagramação: Higor Costa de Brito

Dados Internacionais de Catalogação na Publicação (CIP)

Sueli Costa CRB-8/5213

Legislação na Agronomia [livro eletrônico]: responsabilidade social para um futuro melhor / organização Maria José de Holanda Leite, Andréa de Vasconcelos Freitas Pinto, Luis Alberto Rocha Rodrigues Junior. Campina Grande : Editora Amplla, 2021.

$180 \mathrm{p}$.

\section{Formato: $\mathrm{PDF}$}

ISBN : $978-65-88332-55-9$

1. Agronegócio 2. Desmatamento 3. Amazônia 4. Recursos hídricos I. Leite, Maria José de Holanda II. Pinto, Andréa de Vasconcelos Freitas III. Rodrigues Junior, Luis Alberto Rocha IV. Título

\section{Índices para catálogo sistemático:}

1. Agronomia 630

Editora Amplla

Campina Grande - PB - Brasil contato@ampllaeditora.com.br www.ampllaeditora.com.br 


\section{APRESENTAÇÃO}

O e-book Legislação na Agronomia: Responsabilidade social para um futuro melhor foi um projeto criado pela professora do curso de Agronomia da Universidade Estadual do Maranhão - UEMA Dra. Maria José de Holanda Leite a fim de apresentar as maneiras que a legislação pode ser vista e aplicada em diversas áreas no contexto agrícola.

A confecção dos capítulos, contou-se com a colaboração dos alunos do $6^{\underline{0}}$ período do curso citado, no qual, por meio deles, diversos trabalhos foram feitos a fim de enriquecer os capítulos contidos neste e-book. Cada um conta com um tema distinto onde busca abordar de maneira única um contexto de leis ambientais sendo aplicadas para diversas áreas.

Vale destacar que este livro digital possui autoria livre dos alunos junto com a professora a fim de despertar e aprimorar o interesse pela leitura e produções de trabalhos que enriquecem o meio acadêmico, nesse contexto, este material vem a público com finalidade de apresentar aos leitores as diversas aplicações da legislação e conhecer suas aplicabilidades.

Este e-book visa atender aos estudantes e profissionais dos Cursos de Agronomia, bem como os da Engenharia Florestal, Ambientais e de áreas afins. Os diferentes capítulos versam sobre uma gama de temas como aplicação da PNRH com uso da vazão, Levantamento de áreas desmatadas na Amazonia legal, a Evolução do desmatamento em MATOPIBA levando em consideração seus aspectos relevantes sobre o agronegócio e as políticas governamentais, a Percepção de alunos dos cursos de agronomia e engenharia ambiental sobre as leis ambientais e a Gestão socioambiental e gerenciamento dos resíduos sólidos durante a pandemia do covid19, permitindo que o leitor tenha uma noção geral de cada tema tratado, e caso queira aprofundar, poderá utilizar-se das bibliografias sugeridas e/ou acessar àquelas mais específicas. 


\section{SUMÁRIO}

CAPÍTULO I - AVALIAÇÃO DA VAZÃO DO RIO UNA, COMO INSTRUMENTO DA GESTÃO DE RECURSOS HíDRICOS SEGUNDO POLÍTICA NACIONAL DE RECURSOS HÍDRICOS - 9433/97..................................................................

CAPÍTULO II - LEVANTAMENTO DE ÁREAS DESMATADAS NA AMAZÔNIA LEGAL MARANHENSE ............................30

CAPÍTULO III - EVOLUÇÃO DO DESMATAMENTO EM MATOPIBA: ASPECTOS RELEVANTES SOBRE O AGRONEGÓCIO E AS POLÍTICAS GOVERNAMENTAIS NO PERÍODO DE 2016 A 2021. .50

CAPÍTULO IV - PERCEPÇÃO DE ALUNOS DOS CURSOS DE AGRONOMIA E ENGENHARIA AMBIENTAL SOBRE AS LEIS AMBIENTAIS 76

CAPÍTULO V - GESTÃO SOCIOAMBIENTAL E GERENCIAMENTO DOS RESíDUOS SÓLIDOS DURANTE A PANDEMIA DO COVID-19. . .89 


\section{CAPÍTULO I}

\section{AVALIAÇÃO DA VAZÃO DO RIO UNA, COMO INSTRUMENTO DA GESTÃO DE RECURSOS HÍDRICOS SEGUNDO POLÍTICA NACIONAL DE RECURSOS HÍDRICOS - 9433/97}

DOI: 10.51859/amplla.lar559.1121-1

Domaris Martins Menezes

Universidade Estadual do Maranhão - UEMA, Centro de Ciências Agrárias - CCA, Campus São Luís/MA, Brasil E-mail: domaris-martins@hotmail.com Luis Alberto Rocha Rodrigues Junior

Universidade Estadual do Maranhão - UEMA, Centro de Ciências Agrárias - CCA, Campus São Luís/MA, Brasil E-mail: luisrrjr@hotmail.com

Nahor Daniel Ribeiro Diniz

Universidade Estadual do Maranhão - UEMA, Centro de Ciências Agrárias - CCA, Campus São Luís/MA, Brasil E-mail: nahordiniz@aluno.uema.br Stephen Santos Caldas

Universidade Estadual do Maranhão - UEMA, Centro de Ciências Agrárias - CCA, Campus São Luís/MA, Brasil E-mail: stephencaldas@gmail.com

Clebson Santos Cândido

Universidade Estadual do Maranhão - UEMA, Centro de Ciências Agrárias - CCA, Campus São Luís/MA, Brasil E-mail: cleagro@hotmail.com

Diogo José Oliveira Pimentel ORCID: https://orcid.org/0000-0003-3860-9658 Universidade Federal Rural de Pernambuco - UFRPE, Brasil

E-mail: djopimentel@hotmail.com

Andréa de Vasconcelos Freitas Pinto

ORCID: https://orcid.org/0000-0002-9306-418X Universidade Federal de Alagoas - UFAL, Campus de Engenharias e Ciências Agrárias - CCA, Brasil E-mail: dea_botelho@hotmail.com

Maria José de Holanda Leite ORCID: https://orcid.org/0000-0003-4154-3901 Universidade Estadual do Maranhão - UEMA, Centro de Ciências Agrárias - CCA, Campus São Luís/MA, Brasil E-mail: maryholanda@gmail.com

\section{RESUMO}

A qualidade dos recursos hídricos mundiais está sobre crescente ameaça, devido ao aumento populacional, e a expansão das atividades agrícolas, porém, em contrapartida a essa problemática, leis foram criadas para a preservação desses recursos hídricos, como é o exemplo da Lei 9.433/1997, que instituiu a Política Nacional de Recursos Hídricos e junto a isso, a legislação também busca alinhar tais políticas à sociedade, tendo em vista praticar atos que assegure o consciente uso da água. Nesse sentido, o presente trabalho teve como objetivo realizar a medição da vazão em uma seção pré-estabelecida do Rio Una em Morros - MA, como suporte na aplicação na Política Nacional de Recursos Hídricos na região. A medição de vazão foi realizada em uma seção preestabelecida com o aparelho flutuador e o ADVFlowTracker este, como método mais preciso e comparativo. 0 valor da vazão total da seção foi obtido através da soma das áreas, divididas com auxílio de régua ou barbante, pela velocidade medida por meio de cronometro. Acrescentando o fator de correção 0,8 que considera o valor da velocidade média $60 \%$ abaixo da superfície da água, neste caso, o valor da vazão encontrado foi igual a $20,67 \mathrm{~m}^{3} / \mathrm{s}$. Em 
contraponto, a vazão encontrada com o FlowTracker para a seção de medição total foi igual a 13,43 $\mathrm{m}^{3} / \mathrm{s}$. Quando comparado esse resultado de vazão de $13,43 \mathrm{~m}^{3} / \mathrm{s}$ com a vazão calculada de $20,67 \mathrm{~m}^{3} / \mathrm{s}$ com o uso do flutuador, fica claro que tomandose a apenas a velocidade na superfície da água corre-se o risco de superestimar a vazão do corpo hídrico. Vale pontuar que o uso da água não se consolida somente por meio de uma única medida de vazão e, portanto, e imprescindível que mais estudos e análises a respeito do tema sejam implantados para a região. Além disso, compete ao poder público, implantações de estações fluviométricas e mais consideração com uma região rica em seu aspecto fluvial. Assim, pode-se afirmar que a presente pesquisa contribui como explanador de uma área pouco explorada no estado do Maranhão, sugerindo mais estudos para somar o conhecimento hidrológico do rio Una.

Palavras-chaves: hidrometria, fluvial, flutuador, batimetria.

\section{INTRODUÇÃO}

Os recursos hídricos da microbacia do rio Una, ao longo do tempo vem sofrendo com os impactos causados pelo turismo na região. Verifica-se uma falta de conscientização tanto dos visitantes quanto dos moradores, que acabam despejando lixo nas proximidades do rio. Além disso, destaca-se também a falta de objetivos definidos das políticas de turismo no Maranhão, bem como da gestão local (SILVA, 2003; MARTINS, 2016). Desse modo, conhecer e manejar corretamente os recursos hídricos é essencial, e o conhecimento das vazões é uns dos procedimentos que se deve ser levado em conta (ROCHA et al., 2017).

Segundo Palhares et al. (2007), vazão de um rio consiste no volume de água que percorre entre dois pontos em um determinado intervalo de tempo. Geralmente, é definida em metros cúbicos por segundo $\left(\mathrm{m}^{3} / \mathrm{s}\right)$. A medição da vazão de um rio é fundamental para indicar a quantidade da água para os seres que nele vivem, bem como aqueles que usufruem de suas águas para diversas finalidades (CBHSF, 2016), tais como, abastecimento doméstico, irrigação, aquicultura, navegação, geração de energia entre outras (ANA, 2020).

Desse modo, Martins et al. (2016) alertam a falta de preocupação das autoridades competentes em seguir a legislação vigente, o que dificulta a proteção dos mananciais da região, além da falta de colaboração dos órgãos públicos em investir na infraestrutura da região, e de realizar campanhas que incentive os moradores e visitantes a conservar o local. 
Diante disso, o respeito às leis de preservação desses recursos hídricos é fundamental, como é o exemplo da Lei 9.433/1997, que instituiu a Política Nacional de Recursos Hídricos. Aliado a isso, a legislação também busca alinhar tais políticas à sociedade, tendo em vista praticar atos que assegure o direto ao meio ambiente ecologicamente equilibrado à presente e às futuras gerações. Dessa forma, a água é um importante provedor da vida e é indispensável à sobrevivência (SOUZA; CRUZ, 2013).

A presente pesquisa busca analisar e discutir informações cientificas sobre o rio Una, visto que atualmente tais registros se encontram escassos no âmbito acadêmico, logo, faz-se necessário pesquisar mais afundo acerca do tema em questão. Assim, através da medição da vazão do rio Una, será possível mensurar a quantidade de água presente em determinada seção pré-estabelecida, e como se comportou o uso da água ao longo do tempo no rio. As informações contidas nesse estudo contribuirão com futuros trabalhos acadêmicos sobre o rio Una, além de enriquecer o estudo acerca da Política Nacional de Recursos Hídricos e o uso desse bem.

Este trabalho, que teve como finalidade realizar a medição da vazão em uma seção pré-estabelecida do Rio Una em Morros - MA, como suporte na aplicação na Política Nacional de Recursos Hídricos na região, tem-se como objetivos contextualizar o uso da água de acordo com a PNRH e debater sobre o uso da água de acordo com vazão do curso da água.

\section{REVISÃO DE LITERATURA}

Devido à grande importância do tema, achou-se pertinente fazer uma breve explanação sobre: a) uso da água; b) Importância da medição de vazão de cursos hídricos e; c) Política Nacional de Recursos Hídricos (Lei Federal no 9433/97)

\subsection{0 uso da água}

O Brasil é o país mais rico em abundância de recursos hídricos do mundo, no entanto, os volumes de águas estão distribuídos de forma desigual sobre as regiões hidrográficas, sendo concentrado o maio volume de 73,6\% na bacia Amazônica (CARVALHO et al., 2014). Nesse sentido, é inquestionável a utilidade e bem que a água representa para o homem sendo o fator determinante para a melhoria do seu 
bem-estar e o desenvolvimento das comunidades. Dentre as múltiplas utilidades que a água tem para o ser humano, existe uma que é vital, a de consumo humano, no entanto, há outros usos também indispensáveis para a vida do homem como, por exemplo, na preparação de alimentos e agricultura irrigada. Dentro deste delineamento, questões que abordem o uso da água à medida que esse meio se torna tão essencial para o ser humano vem se mostrando no que diz respeito a necessidade de articulação do planejamento de recursos hídricos com o dos seus setores usuários, com o planejamento regional, estadual e nacional, pois de nada adianta gerenciar as águas sem que sejam conhecidas as demandas dos diversos setores que a utilizam. (CARVALHO et al, 2014; PEDROSA, 2017)

O Brasil está entre os quatro países com maior área potencial para irrigação, embora apenas uma pequena parte seja utilizada. 0 grande potencial se deve tanto à extensão territorial quanto ao conjunto de fatores físico-climáticos favoráveis ao desenvolvimento da atividade e, segundo (CARVALHO, 2014) esse setor agrícola é responsável pela maior parte do uso consuntivo da água no Brasil, requerendo maior atenção dos órgãos gestores com vistas ao desenvolvimento sustentável dos recursos hídricos.

A quantidade de água na terra é praticamente invariável no tempo, modificando-se apenas sua forma substancial e seu estado físico. Do total de água precipitada, uma parte alcança a superfície terrestre, já que na sua queda parte volta a evaporar. Do total que atinge a superfície terrestre, uma parcela que não retorna a atmosfera pela evaporação e evapotranspiração direta, constitui o que se chama de recursos hídricos internos renováveis.

Segundo Carvalho et al (2014) a parte que não infiltra no solo irá formar o escoamento superficial total dos rios e em seu percurso, a água estará sujeita a infiltração em material permeável ou a descarga em corpos d’água, alimentando rios, lagos ou a descarga direta nos oceanos. Da água que precipita sobre as áreas continentais, calcula-se que a maior parte se infiltra (60 a 70\%), sendo pequena a parcela que escoa superficialmente (30 a 40\%), sendo as águas de infiltração importantes processos na regularização das vazões dos rios.

O Brasil enfrenta um dos maiores desafios que é o gerenciamento dos recursos hídricos disponíveis, dado os inúmeros problemas relacionados ao conhecimento da quantidade e qualidade desses recursos, tanto em nível global 
como regional. Nesse contexto, o conhecimento das condições hídricas em pequenas bacias é uma ferramenta primordial no gerenciamento dos recursos hídricos frente ao cenário atual de degradação das águas e a necessidade crescente de novas fontes de abastecimento (CARVALHO et al., 2014). A avaliação de disponibilidade hídrica de uma bacia depende, além de profissionais capacitados, como também de algumas ferramentas que auxiliam neste levantamento.

Para que o modelo de utilização das águas se torne coeso, se faz necessário os levantamentos acerca da fonte, tornando-a apta para retirada e utilização adequada da água, além disso, exigências legais e instrumentos de gestão, como a outorga de direito de uso água, fomentam o aumento da eficiência e a consequente redução do desperdício. Os conflitos pelo uso da água podem envolver questões políticas de desenvolvimento regional, e podem depender de intrincadas relações entre biologia, química, oceanografia, hidrologia e hidráulica. Comumente, há necessidade de integrar vários órgãos públicos e privados com competências e interesses pelo uso da água. Também é comum a necessária acomodação de interesses entre os municípios, os estados e a União. (ANA, 2013; PEDROSA, 2017).

\subsection{Importância da medição de vazão de cursos hídricos}

0 regime fluvial de um rio é determinado por fatores relacionados à interação entre as condições climáticas e a fisiologia da bacia. Além da chuva que cai diretamente sobre os rios, a precipitação sobre pontos mais distantes das bacias hidrográficas que chega ao rio principal por escoamento superficial e subsuperficial, contribui consideravelmente para a vazão (CAPOZZOLI et al., 2017).

Vários países dispõem de arranjos institucionais e administrativos que possibilitam o tratamento adequado da gestão das águas e no Brasil se dispõe de uma das mais modernas legislações de recursos hídricos, instituída pela Lei no 9.433 de 1997, que sanciona, por exemplo

o uso de outorgas, que permite ao seu detentor, por um período preestabelecido, o direito de uso de determinada quantidade de água, condicionado a sua disponibilidade. Esta disponibilidade está condicionada a medida da vazão adotadas pelos órgãos gestores de recursos hídricos e influenciam diretamente no total disponível para outorga (SILVA et al, 2015). 
O estudo da medição de vazão possui sua importância no gerenciamento de pesquisas futuras detalhes mais precisos do comportamento dos corpos hídricos, analisando períodos de cheia dos rios como exemplo, onde a vazão pode diminuir consideravelmente. Dados como este trazem uma abrangência de estudos em relações a cursos fluviais que são ricos em relação a suas extensões geográfico e muito presentes do Brasil (BEZERRA et al, 2017).

Além disso, o estudo da vazão de um corpo hídrico norteia vários parâmetros para o uso da água, nesse sentido, a legislação voltada para o tal uso coerente e correto se dá por meio de outorgas, aparelho adotado pela Agência Nacional de Águas para assegurar e sistematizar o uso deste recurso natural (ANA, 2013).

\subsection{Política Nacionall de Recursos Hídricos (Lei Federal oํ} 9433/97)

De acordo com a Lei Nacional n 9.433, de janeiro de 1997, a PNRH se baseia em seis fundamentos.

1 - A água é um bem de domínio público;

2 - A água é um recurso natural limitado, dotado de valor econômico;

3 - Em situações de escassez, o uso prioritário dos recursos hídricos é o consumo humano e a dessedentação de animais;

4 - A gestão dos recursos hídricos deve sempre proporcionar o uso múltiplo das águas;

5 - A bacia hidrográfica é a unidade territorial para implementação da Política Nacional de Recursos Hídricos e atuação do Sistema Nacional de Gerenciamento de Recursos Hídricos;

6 - A gestão dos recursos hídricos deve ser descentralizada e contar com a participação do Poder Público, dos usuários e das comunidades (BRASIL,2021).

A iniciativa do Governo Federal, por meio da SRH/MMA, em resgatar e priorizar o estabelecimento de processos de planejamento, de médio e longo prazos, é de suma importância para o fortalecimento, a continuidade e a integração de políticas públicas correlatas e para o norteamento das ações do Estado brasileiro no campo dos recursos hídricos.

O PNRH vem ao encontro dessa ação estratégica e as bases conceituais para a sua construção estão alicerçadas nos fundamentos, nos objetivos e nas diretrizes 
gerais de ação, previstos na Lei Federal no 9.433/1997, destacando-se: a ratificação da dominialidade pública das águas; a prioridade para o consumo humano e para a dessedentação de animais em situações de escassez; os usos múltiplos das águas; seu valor econômico; a bacia hidrográfica como unidade territorial para implementação da política; a descentralização e a participação social no processo de gestão; a utilização integrada e sustentável da água; os conceitos de integração e articulação, tanto do ponto de vista dos processos socioambientais quanto políticos e institucionais.

A lei da Política Nacional de Recursos Hídricos avança e opera uma verdadeira transformação no mundo jurídico das águas brasileiras. Rompeu conceitos e paradigmas arraigados na tradição legislativa pátria em matéria de recursos hídricos, a começar, por exemplo, pelo reconhecimento expresso de sua finitude ao dizer, em seu artigo $1^{\circ}$, que "a água é um recurso natural limitado, dotado de valor econômico".

Os fundamentos da Lei no 9.433/1997 indicam novos rumos em matéria de gestão das águas, a começar pelo entendimento jurídico-legal de que a superação dos graves problemas ecológicos atuais e a condução do desenvolvimento econômico rumo a cenários socioambientais sustentáveis passa pelo cruzamento das questões ecológicas, socioeconômicas e político-financeiras de sustentabilidade do sistema de gestão dos recursos hídricos. Requer, portanto, a acuidade e o debate democrático permanentes e representa a razão prática que confirma a necessidade crescente da participação de todos no planejamento e na gestão das águas (ANA,2021).

Neste contexto de gestão democrática das águas, a PNRH estabelece como instrumento de gestão, a outorga de direito de uso da água que determina o quanto e como cada usuário do recurso hídrico deverá usar a água. Conforme a lei 9.433 de 1997, as atividades dependentes de outorga são as seguintes:

- Derivação ou captação de parcela da água existente em um corpo d'água para consumo final, inclusive abastecimento público, ou insumo de processo produtivo;

- Extração de água de aquífero subterrânea para consumo final ou insumo de processo produtivo; 
- Lançamento em corpo d'água de esgotos e demais resíduos líquidos ou gasosos, tratados ou não, com o fim de sua diluição, transporte ou disposição final;

- Aproveitamento dos potenciais hidrelétricos;

- Outros usos que alterem o regime, a quantidade ou a qualidade da água existente em um corpo d'água.

A legislação hídrica discutida condiciona de um modo geral o uso da água, logo, atributos relacionados ao contexto de uso, no que diz respeito ao seu estudo e aplicação, se torna importante quando abordado na aplicação da legislação agrária. Nesse sentido, o profissional que aplica tais leis precisa conhecer os processos de aplicação, neste caso, destacando a correta medição de vazão e suas aplicações, como por exemplo, aplicação da outorga. Por fim, o debate do uso da água envolve um contexto muito além de leis, uma abordagem social e política se faz necessário para o enriquecimento da região estudada.

\section{MATERIAL E MÉTODOS}

\subsection{Caracterização da área de estudo: Bacia hidrográfica do Rio} Munim e microbacia do Rio Una

A bacia do Rio Munim, vista na Figura 1, possui grande importância regional e que deságua na baía de São José e é cercado pelos municípios de Axixá e Icatu. Com aproximadamente $331,74 \mathrm{~km}$ de extensão, suas nascentes localizam-se nos Tabuleiros da Formação Barreiras, a nordeste do município de Caxias (NUGEO, 2016). Estendendo-se por 1.712,121 km² (IBGE, 2020) e com 19.572 habitantes no último censo (IBGE, 2020). Sua população é de 10,37 hab $/ \mathrm{km}^{2}$ (IBGE, 2010). Está situada a 476 metros de altitude, tendo as seguintes coordenadas geográficas: Latitude: $9^{\circ} 27^{\prime} 1^{\prime \prime}$ Sul, Longitude: $46^{\circ} 17^{\prime}$ 53" Oeste. Os afluentes que compõem a rede hidrográfica do Rio Munim são o Una, Bacuri, Piranji, Água Fria, Flexeira e Periá (SOUZA, 2016). 


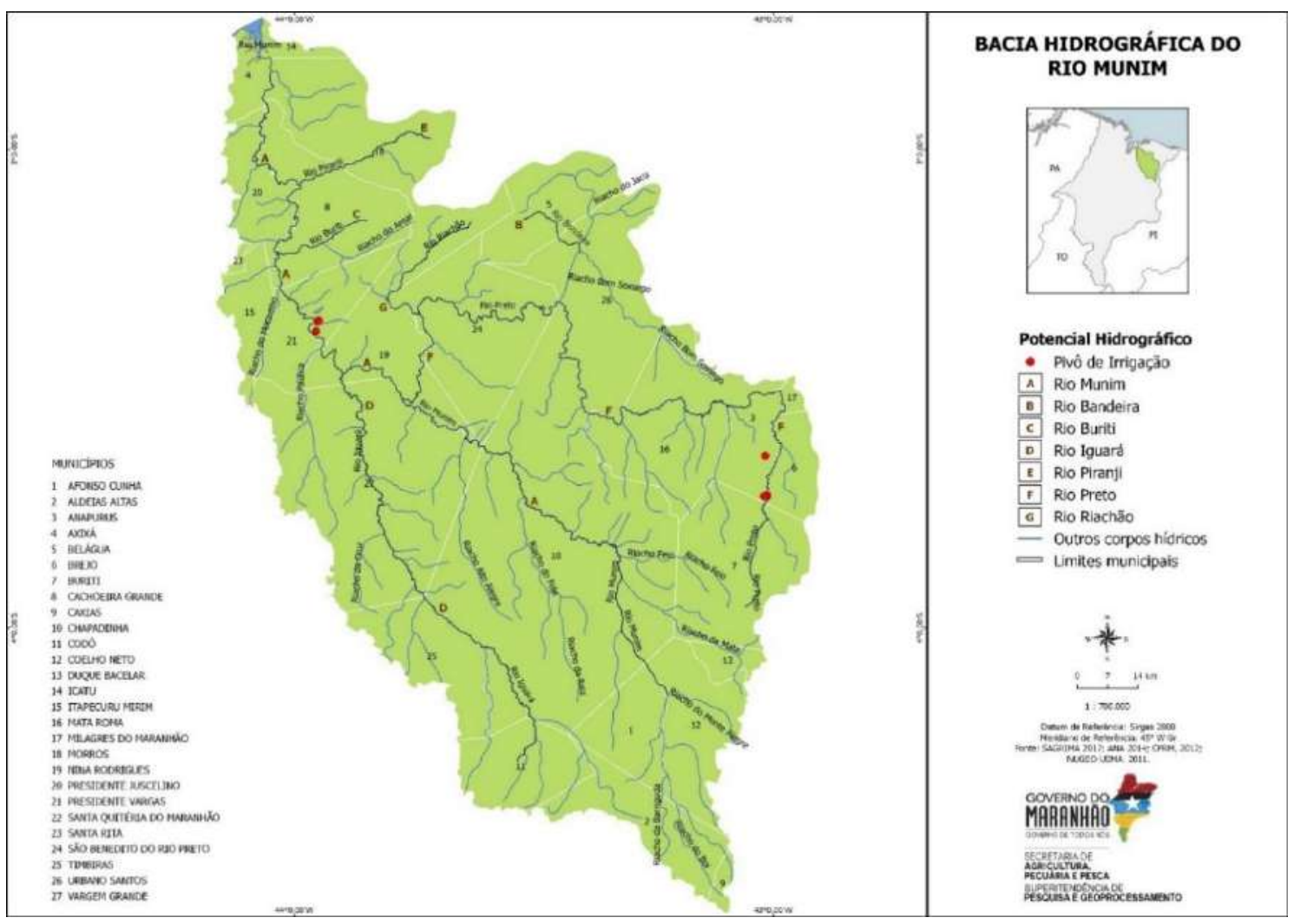

Figura 1. Delimitação geográfica Bacia do Rio Munim

Fonte: SAGRIMA, 2010.

Localizado na parte norte do estado do Maranhão, o Rio Una (Figura 2) é pertencente à bacia do Rio Munim e se estende por áreas dos municípios de Morros e Cachoeira Grande (SILVA, 2003). O povoado Barato, próximo de Piriquita do Amaro é onde nasce o rio Una e compreende cerca de oito povoados no qual inclui a sede do município, estendendo-se por $35 \mathrm{~km}$ com seu encontro no povoado de Una dos Moraes onde suas águas se confundem as do rio Munim. Os seus afluentes são o rio Centro do Anajá, rio Contrato, rio Arruda, Igarapé São Benedito (riacho Mato Grosso), riacho do Saara e una da Felipa, e são classificados como perenes (MARTINS, 2016). 


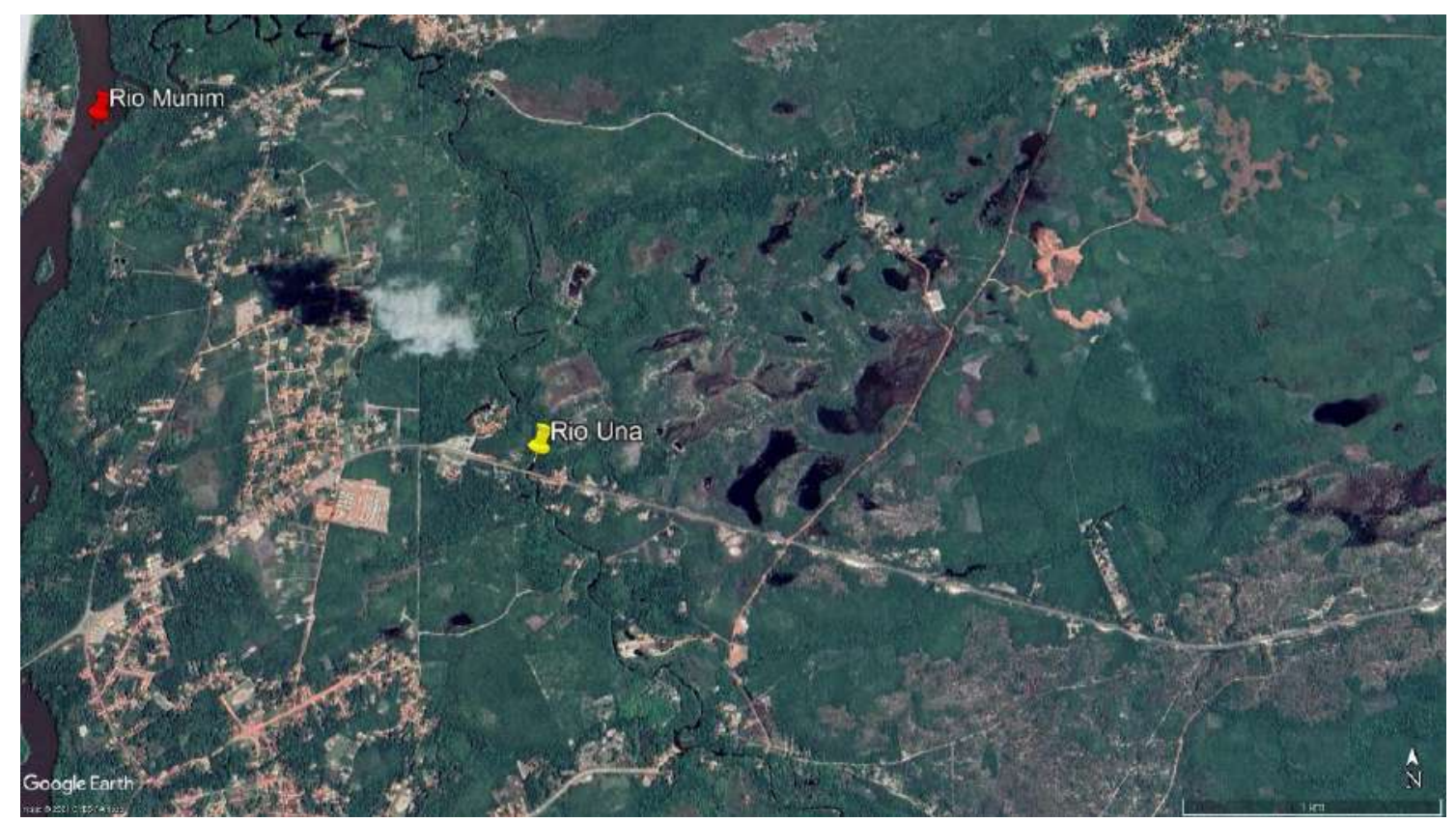

Figura 2. Mapa de localização do Rio Uma.

Fonte: Google Earth, 2021.

Segundo Souza (2016) o nome Una tem seu significado em Tupi que quer dizer "negro", entretanto mostra-se um curso d'água dourado em razão dos raios solares e apresenta uma areia branca e fina. Não ocorre enchentes o que se torna favorável para atividades de turismo, no seu baixo curso o rio Una sofre penetração das águas da maré com uma extensão de aproximadamente $2 \mathrm{~km}$ o qual favorece atividades de banho regular para os turistas o que pode implicar em diversos riscos.

São sucessivos os impactos causados a micro bacia do rio Una ao longo desses anos, estando ligados principalmente a comunidade e a população que recebe turistas dentro do município. Esses impactos são resultados de objetivos mal definidos tanto pela administração da região quanto políticas públicas relacionadas ao turismo no estado do Maranhão (MARTINS, 2016).

\subsection{Medição de vazão em seção preestabelecidla do Rio Una}

A medição de vazão foi realizada em uma seção preestabelecida que está localizado a 2o 51'41,983”' S e 44ํ1' 32,539” W no dia 17 de junho de 2021 (Figura 3) que, segundo Bonifácio \& Freire (2013), considera-se para tal, a facilidade de acesso, linearidade e ausência de obstáculos. Nesse sentido, a área escolhida 


\section{[}

localiza-se no Rio Una, Morros - MA, com característica de largura de 32,5 m, e com profundidade média entre 113 a $132 \mathrm{~cm}$.

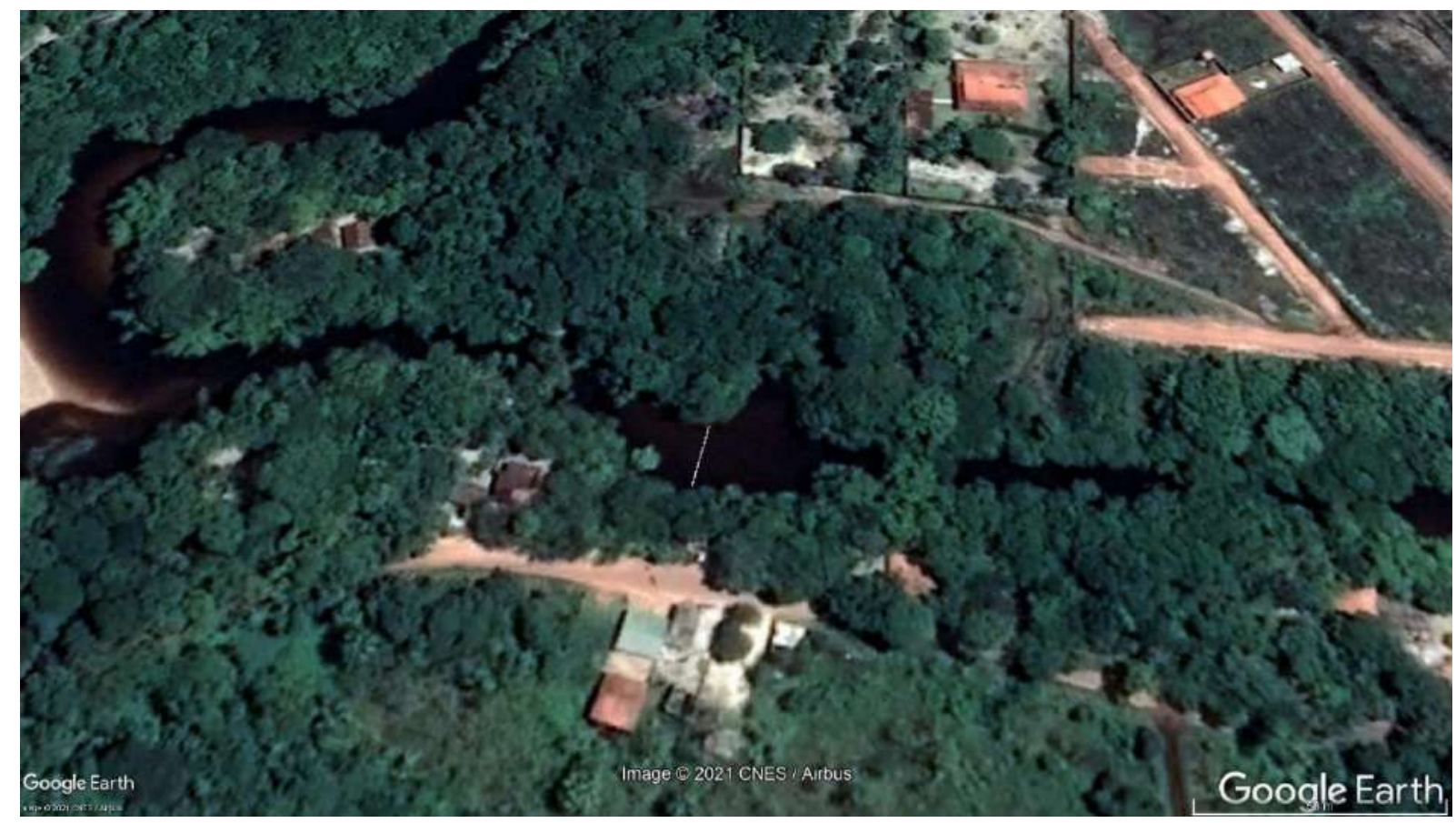

Figura 3: Seção de medição. *Legenda: Linha da seção de medição (Traço branco).

Fonte: Google Earth, 2021.

Após definida a seção de medição, procedeu-se com a coleta das variáveis envolvidas para determinação da vazão em canais abertos, são elas: a velocidade de escoamento da água e área molhada da seção.

No primeiro momento, para determinar a velocidade da água utilizou-se um flutuador (garrafa plástica de 5 litros) posicionado a montante de um trecho de 8 metros delimitado por cordas posicionadas em sentido transversal ao rio (Figura 4). Em seguida, procedeu-se com a coleta do tempo médio gasto pelo flutuador para percorrer o trecho delimitado (BONIFÁCIO; FREIRE, 2013). Com isso, foi possível determinar a velocidade média da água através da relação espaço percorrido (8 metros) /tempo gasto (s). 


\section{प}

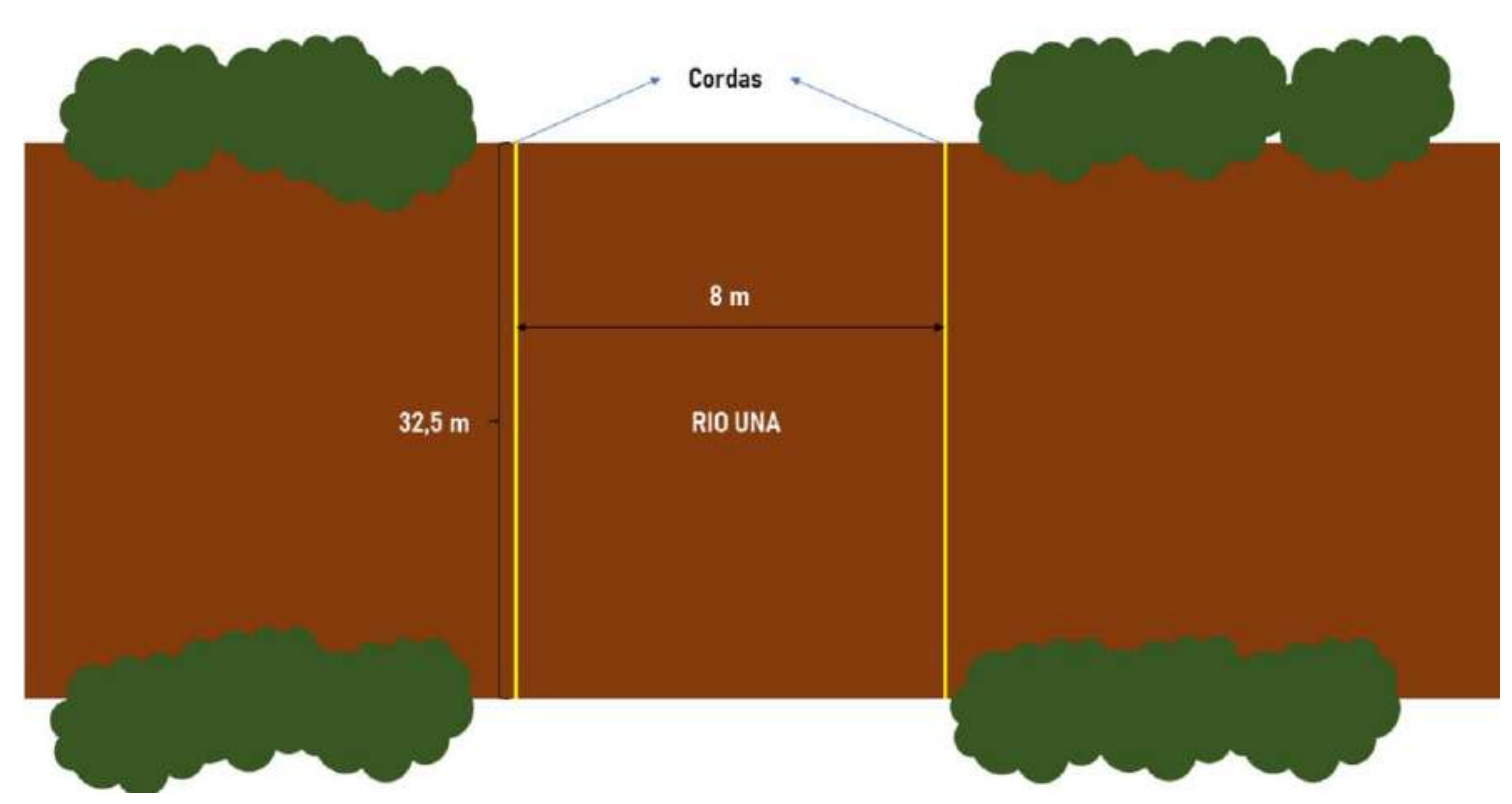

Figura 4. Croqui da seção delimitado no Rio Una.

Fonte: Próprios autores, 2021.

Quanto ao cálculo da área molhada, com o uso da trena, procedeu-se com a divisão da seção de medição em 32 verticais distanciadas entre si de 1 m (Figura 5).

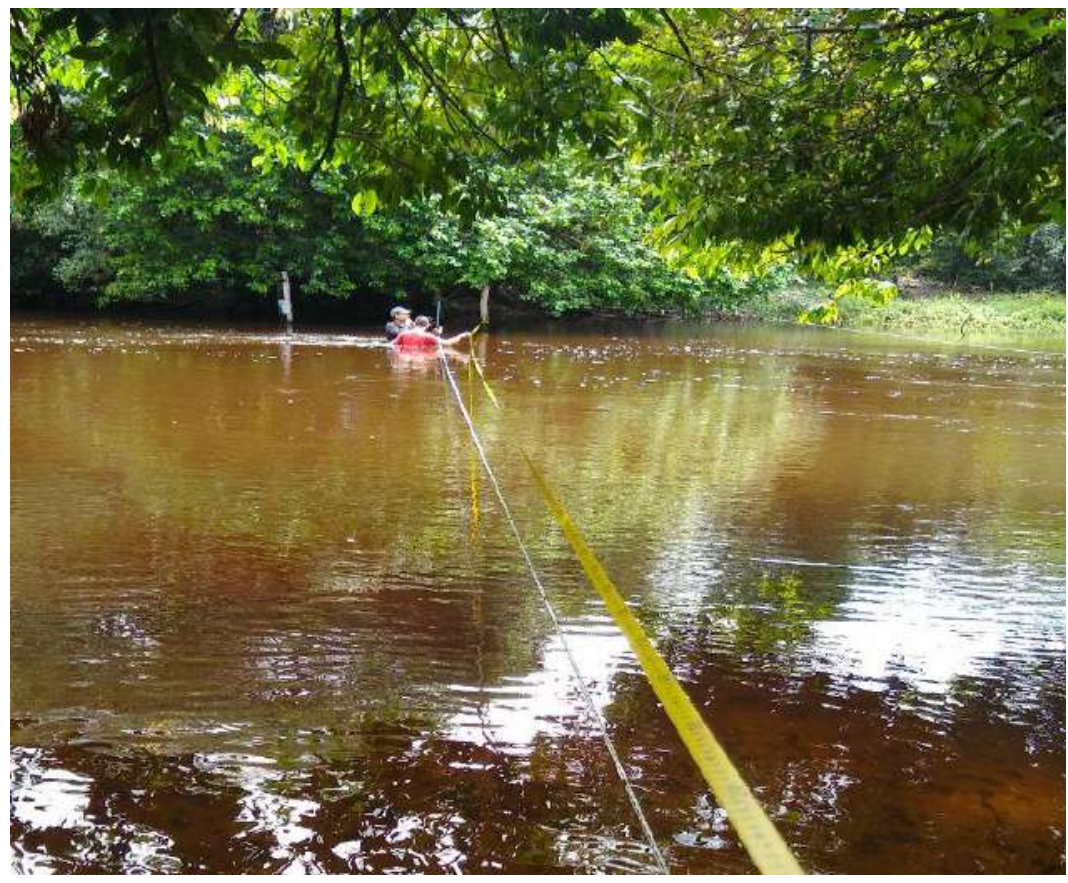

Figura 5. Medição da largura total da seção de medição com fita métrica.

Fonte: Próprios autores, 2021. 
Após isso, foram coletadas as profundidades em cada vertical com o uso de haste graduada e por fim pelo método da meia seção determinou-se as subáreas correspondentes a cada vertical, como mostra a fórmula a seguir:

$$
A=p_{i}\left(\frac{\left(d_{i}+d_{i+1}\right)}{2}-\frac{\left(d_{i-1}+d_{i}\right)}{2}\right)
$$

Equação 1

Por conseguinte, a vazão do Rio Una será o produto do somatório das subseções encontradas pela velocidade média da água, como mostra a fórmula a seguir:

$$
Q=\left(\left(\sum_{i=1} A\right) \times V\right)
$$

\section{Equação 2}

Onde:

Q - Vazão total da seção do Rio Una;

$\sum_{i=1} A$ - Soma das áreas transversais da seção $\left(\mathrm{m}^{2}\right)$;

$V=$ Velocidade $(\mathrm{m} / \mathrm{s})$.

No segundo momento, a medição de vazão do rio Una foi feita com o medidor acústico de vazão FlowTracker. Foram selecionadas algumas verticais já estabelecidas anteriormente para posicionar o equipamento e assim determinar a velocidade da água em duas profundidades em cada vertical (20\% e 80\% em relação a superfície da água). Para determinação da velocidade da água, o Flowtracker usa efeito Doppler medindo a mudança na frequência do som que é refletido das partículas na água. Os medidores de vazão que utilizam o efeito Doppler ficaram conhecidos como ADCPs, ou Acoustic Doppler Current Profilers (GAMARO et al., 2007). Isso possibilita maior precisão dos dados de velocidade e consequentemente melhor resultado de vazão.

\subsection{Debate acerca do valor da vazão}

O valor encontrado no cálculo de vazão servirá como suporte de discussão no que diz respeito a como pode ser aplicado esse dado para o melhor uso da água. Essa base argumentativa será assegurada por meio de pesquisas bibliográficas a respeito do uso da água, levando em considerações também, características de uso já identificadas para o Rio Una. Além disso será dada atenção quanto ao uso múltiplo 
da água preconizado na Política Nacional de Recursos Hídricos (PNRH) - 9433/97 e regulamentado pela necessidade de obtenção da outorga de direito de uso da água pelos usuários de recursos hídricos. A adequada alocação do recurso hídrico entre diferentes usuários depende do monitoramento hidrológico a longo prazo com o objetivo de determinar as vazões de referências (Q90 e Q95) do corpo hídrico estudado. Sendo assim, é de extrema importância a determinação da vazão de referência dos corpos hídricos estaduais para melhor gestão das águas e redução de conflitos.

\section{RESULTADOS E DISCUSSÃO}

\subsection{Medição de vazão utilizando o flutuador}

Através de uma haste metálica graduada, foram determinadas as profundidades em cada vertical da SM (seção de medição) e, em seguida, traçada a geometria da seção (batimetria) (Figura 6). A batimetria da seção é um parâmetro essencial para que se possa observar as mudanças ocorridas no fundo do rio ao longo dos anos. Essas mudanças podem estar relacionadas com processos de assoreamento ocorridos na bacia hidrográfica.

\section{Dados de batimetria na seção de medição}

\section{Verticais}

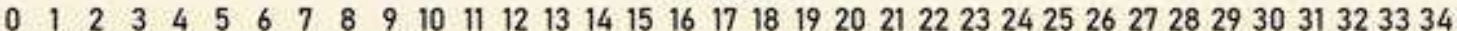

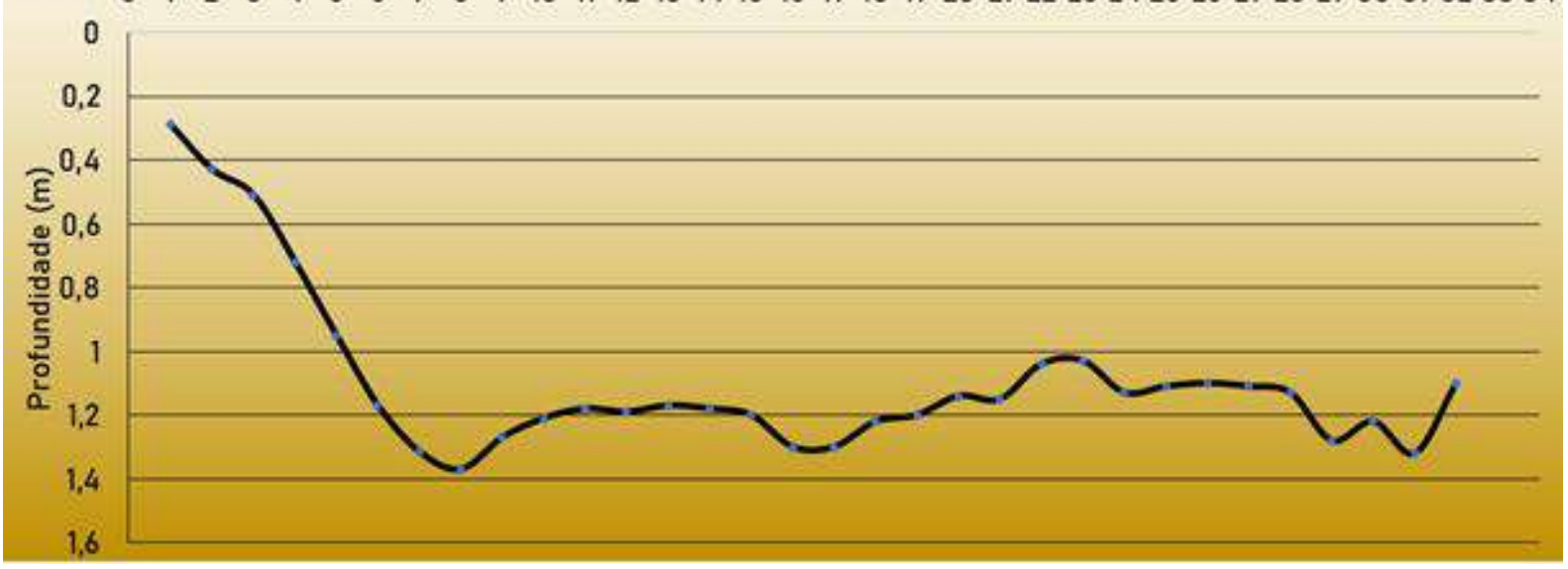

Figura 6. Geometria da seção de medição.

Fonte: Próprios autores, 2021. 
Analisando-a percebe-se que há uma regularidade na SM quanto a profundidade. Essa característica geométrica regular da SM auxiliou no cálculo da área molhada. Considerando a geometria retangular da SM, a área molhada encontrada foi $34,45 \mathrm{~m}^{2}$ (largura do rio: 32,5 $\mathrm{m}$ x profundidade média: 1,06 $\mathrm{m}$ ).

Como dito anteriormente, a outra variável envolvida no cálculo de vazão é a velocidade da água. Como premissa básica da medição de vazão adota-se a velocidade da água como sendo a relação entre espaço percorrido pelo flutuador (8 metros) delimitado por cordas e o tempo médio gasto por ele para percorrer este espaço.

A escolha do trecho levou em consideração algumas características como a ausência de intempéries na superfície como redemoinhos ou remansos que, segundo Carvalho et al. (2014) a presença desses fenômenos interfere na velocidade do flutuador.

Para a estimativa do tempo, foram realizadas 4 medições do tempo percorrido pelo flutuador no trecho supracitado (Figura 7).

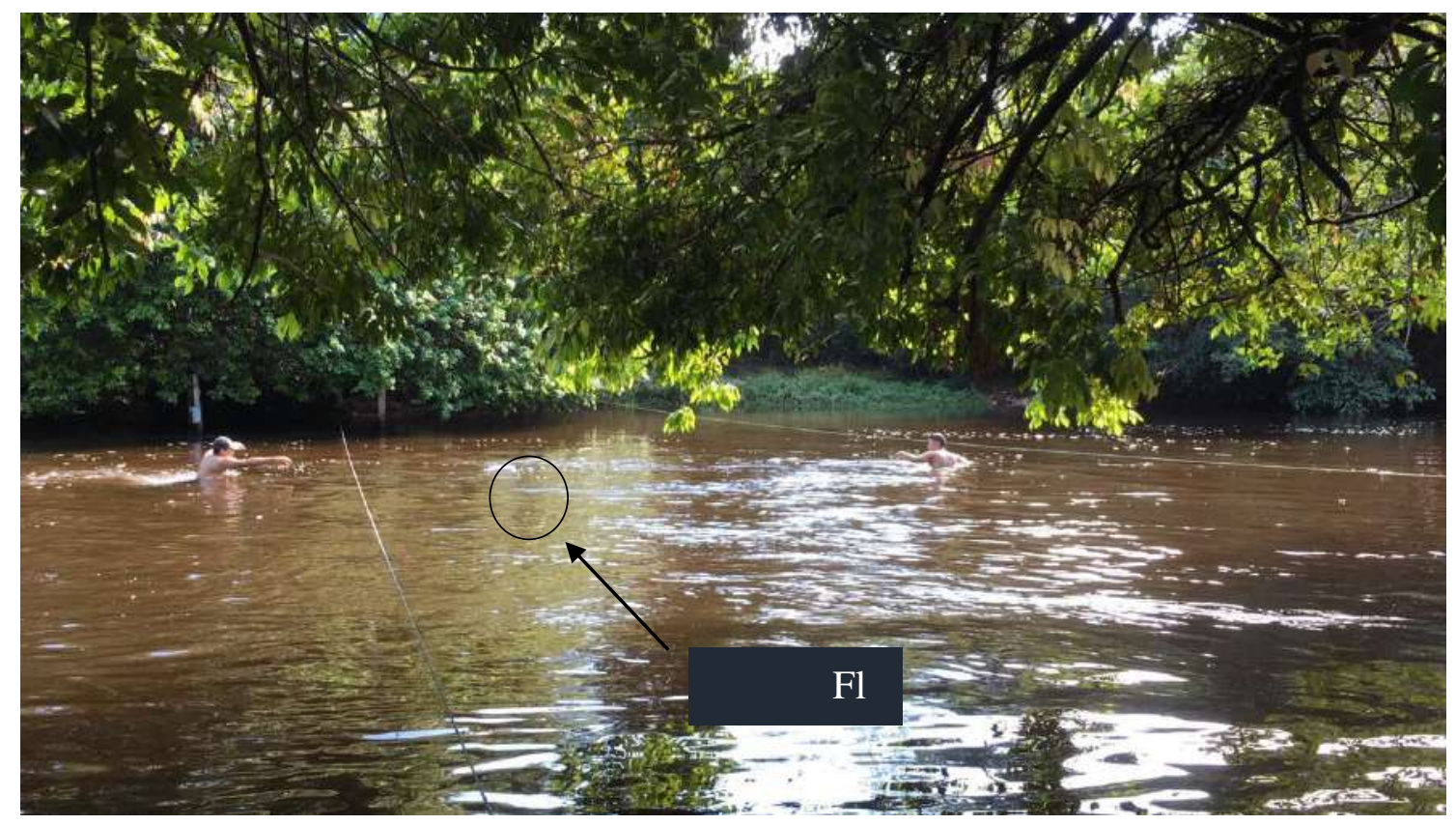

Figura 7. Lançamento do flutuador na SM para estimativa do tempo.

Fonte: Próprios autores, 2021.

Pode-se contatar que, há uma variação dos tempos cronometrados devido as condições do local e a possíveis erros no lançamento do flutuador. Por isso a amostragem em quadruplicata é importante para definir um valor médio do tempo 
gasto e assim proporcionar maior precisão no cálculo da velocidade da água (Figura 8). Após essa análise estatística, definiu-se o tempo médio gasto pelo flutuador de $10,5775 \mathrm{~s}$.

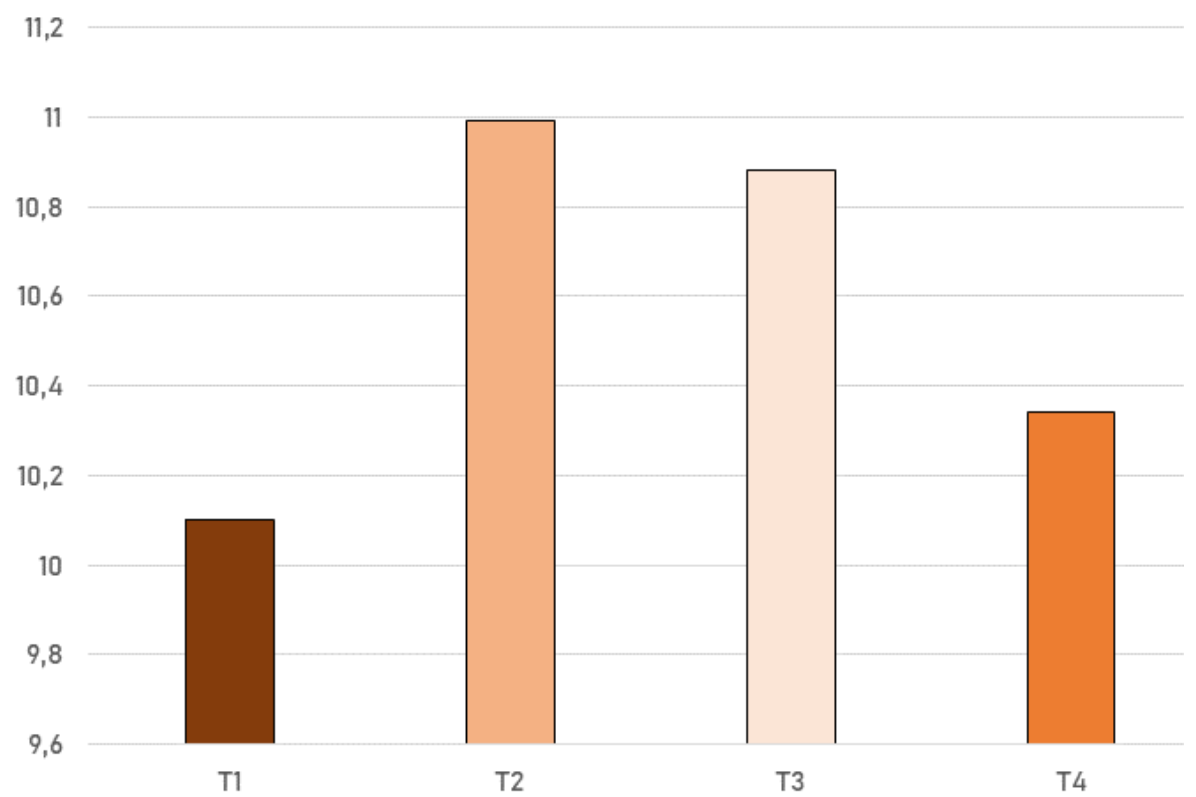

Figura 8. Tempos cronometrados da seção longitudinal pelo método do flutuador. *Legenda: $\mathrm{T}=$ Tempo(s).

Fonte: Próprios autores, 2021

Dado os valores descritos, foi possível determinar a velocidade média da água com o uso do flutuador de $0,75 \mathrm{~m} / \mathrm{s}$. Vale ressaltar que com o uso do flutuador considera-se apenas a velocidade na superfície da água.

Segundo Bezerra et al (2017), o resultado da vazão em uma coluna d'água pode se diferenciar conforme aumenta a profundidade, nesse sentido, foi utilizado a equação 2 descrita no item 2.2 da metodologia acrescentando o fator de correção 0,8 que considera o valor da velocidade média 60\% abaixo da superfície da água, neste caso, o valor da vazão encontrado foi igual a $20,67 \mathrm{~m}^{3} / \mathrm{s}$.

\subsection{Medição de vazão utilizando o FlowTracker}

O equipamento ADV - FlowTracker (Figura 9) consegue realizar a medição de vazão de maneira automática utilizando diferentes métodos de medição configurados no firmware do equipamento. 0 método da meia seção foi selecionado pois considera as vazões referentes a cada subárea da vertical selecionada. Assim é 


\section{Q}

possível ter uma integração de subvazões que representa bem o perfil do rio estudado.

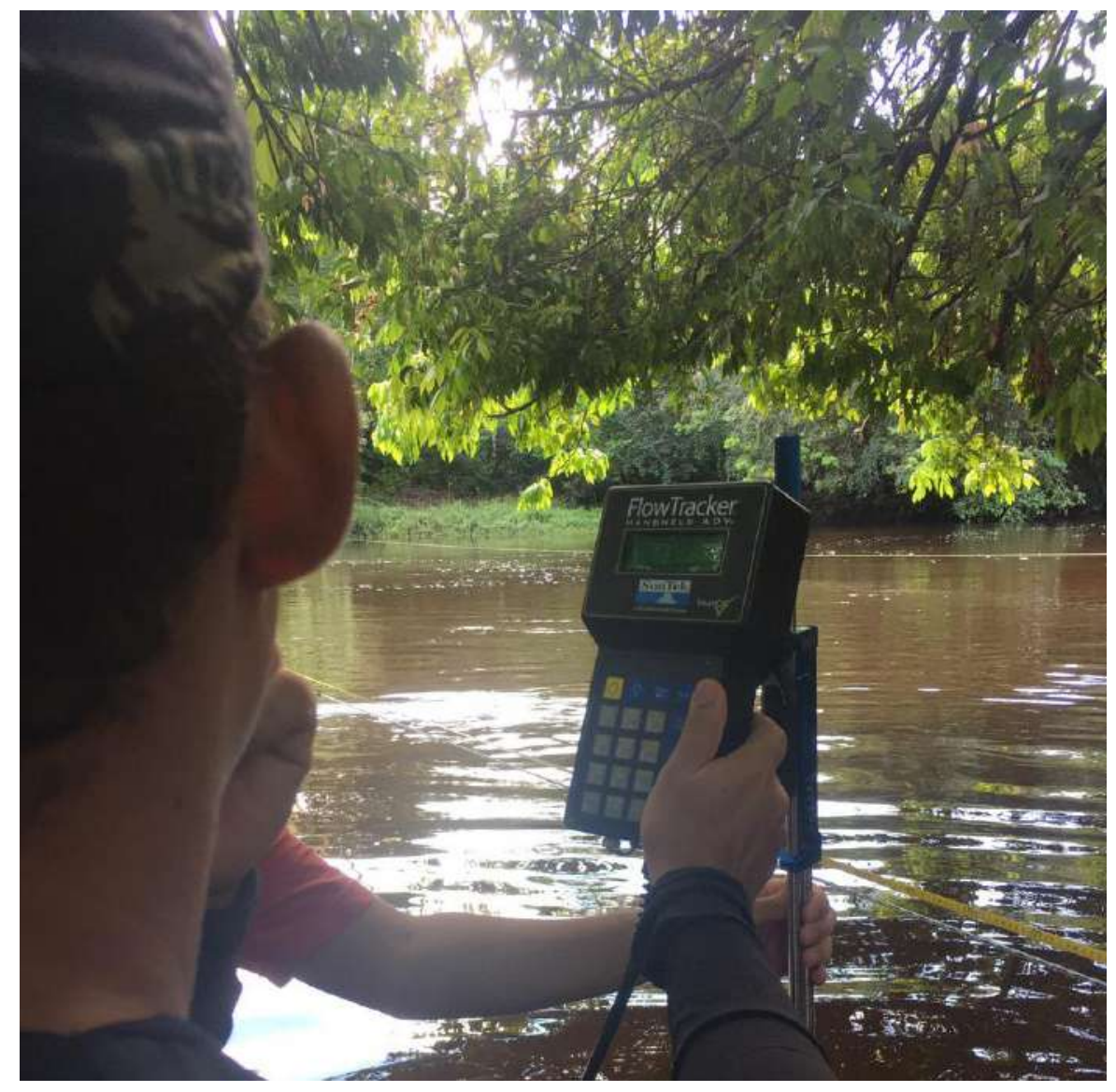

Figura 9. ADV - FlowTracker.

Fonte: Próprios autores, 2021.

Para determinação da velocidade da água, foram selecionadas 13 verticais da SM e em cada vertical o sensor do Flowtracker foi posicionado a profundidade de $20 \%$ e $80 \%$ em relação a superfície da água para aferição das velocidades (Figura 10). 


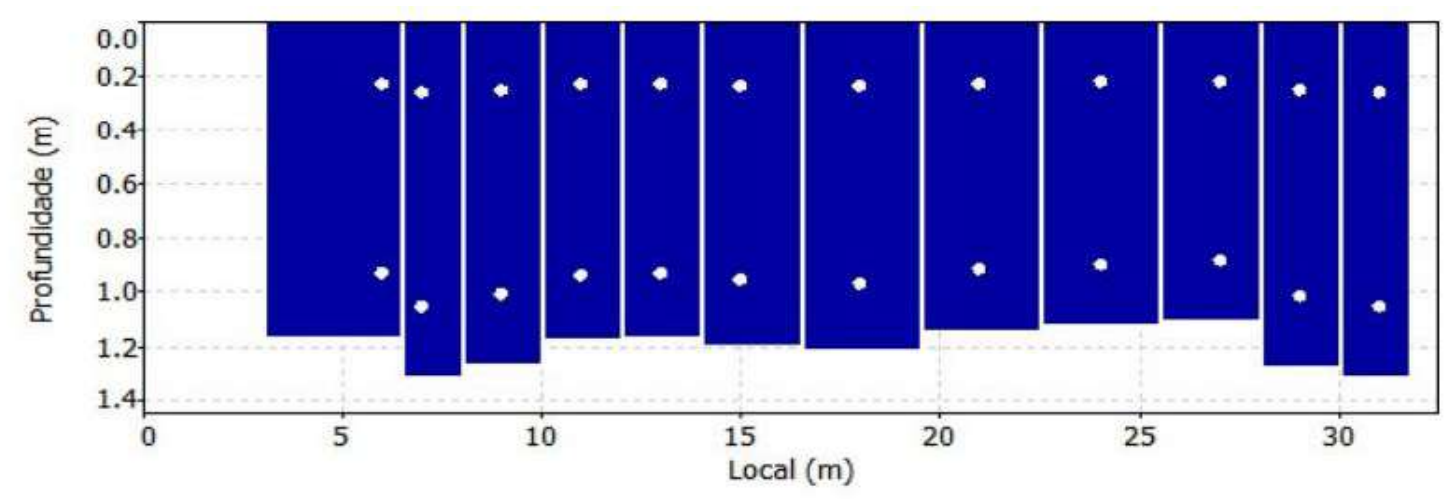

Figura 10: Profundidade de cada vertical medida pelo FlowTracker.

Fonte: Próprios autores, 2021.

Desse modo obteve-se a velocidade em cada vertical pela média dos valores encontrados a $20 \%$ e $80 \%$ de profundidade (Figura 11). 0 tempo estabelecido para coleta de dados em cada vertical foi de $40 \mathrm{~s}$, devidamente programado no firmware do aparelho FlowTracker.

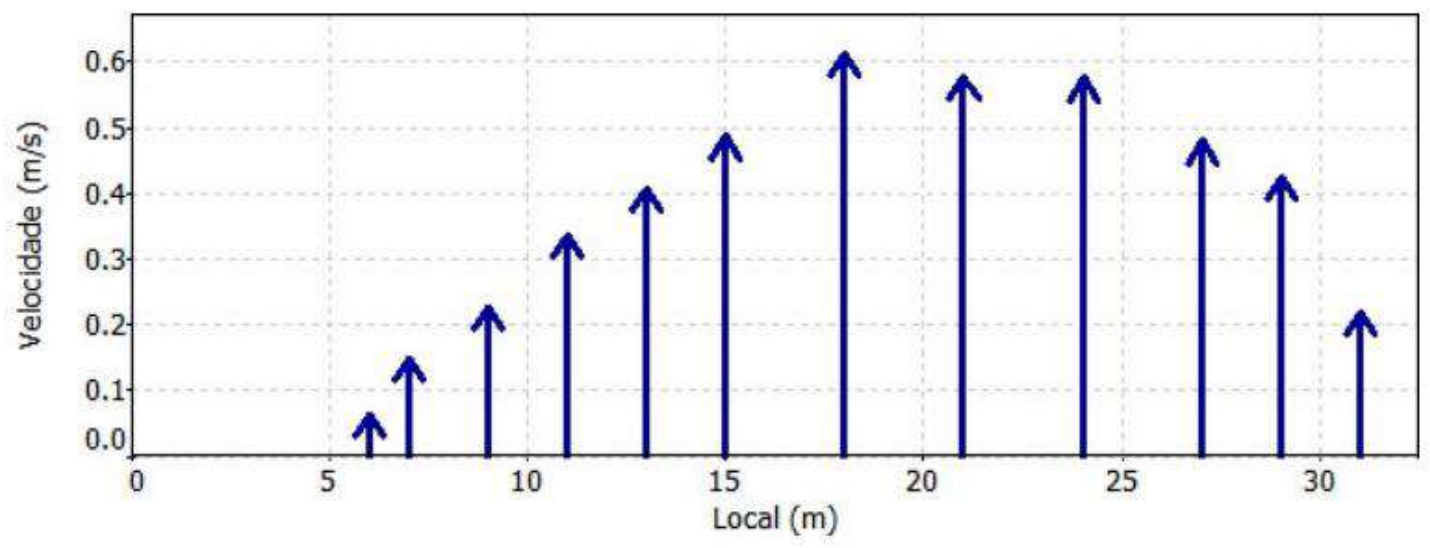

Figura 11. Velocidade calculada pelo FlowTracker em cada vertical.

Fonte: Próprios autores, 2021.

As figuras 10 e 11 se correlacionam, uma abordando a profundidade em cada vertical e a outra apresentando a velocidade catalogada em cada uma delas. Porém, vale destacar as profundidades apresentaram uma linearidade em suas medidas, o que leva a crer que o leito do rio estudado possui uma geometria bem regular, algo já observado quando analisado o Figura 6 além disso as velocidades nas verticais localizadas no meio do rio apresentaram maiores valores quando comparado as 
verticais próximas as margens. Já a figura 12 apresenta as vazões calculadas em cada seção vertical selecionada:

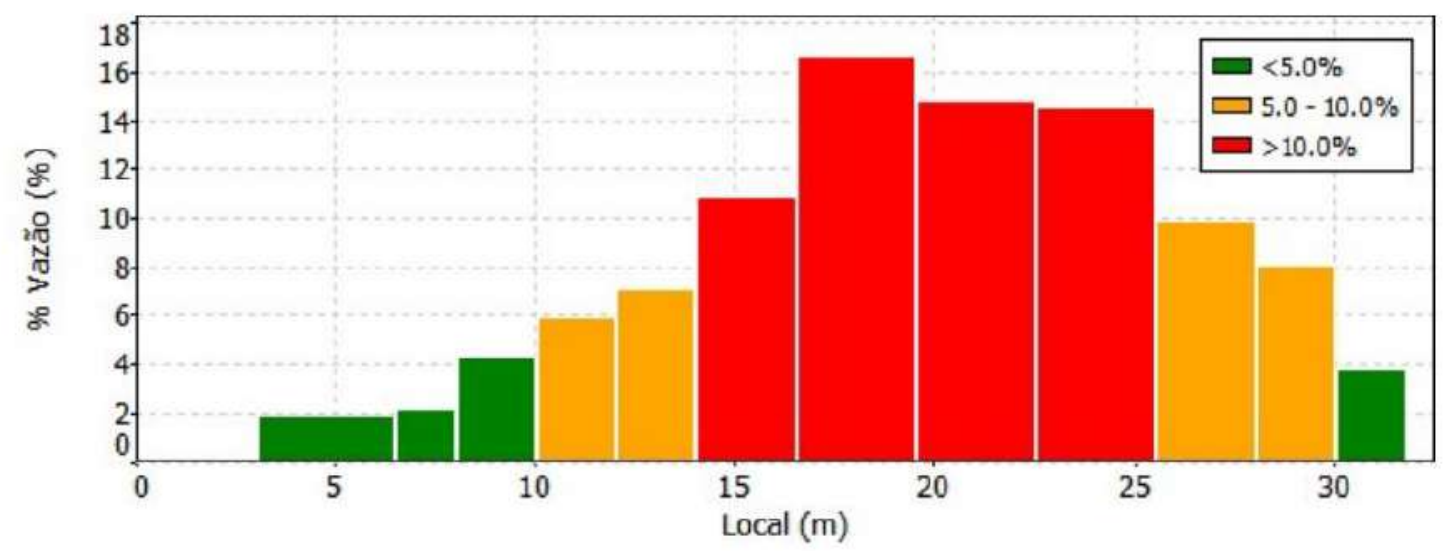

Figura 12. Vazão medida pelo FlowTracker em cada seção vertical.

Fonte: Próprios autores, 2021.

A característica apresentada na figura 11, pode ser comprovada pela figura 12 haja vista que os valores de velocidade média estão em relação direta com os valores da vazão, em outras palavras, quando maior for a velocidade média das seções, maiores os valores de vazão registrados para aquelas.

Nesse sentido, a vazão encontrada com o FlowTracker para a seção de medição total foi igual a 13,43 m³/s. Quando comparado esse resultado de vazão de $13,43 \mathrm{~m}^{3}$ /s com a vazão calculada de $20,67 \mathrm{~m}^{3}$ /s com o uso do flutuador, fica claro que tomando-se a apenas a velocidade na superfície da água corre-se o risco de superestimar a vazão do corpo hídrico.

Segundo Rocha et al (2017), o método do flutuador não é considerado uma alternativa viável se comparado ao "método acústico" para análises mais precisas, neste caso, o aparelho FlowTracker apresenta uma vazão bem mais representativa quando comparada a vazão encontrada pelo flutuador.

\subsection{0 uso dla água baseadlo na vazão dlo rio Una}

Dentre os pontos destacados, a vazão determinada neste trabalho para o rio Una servirá como prospectora de estudos mais profundos acerca do rio que corta uma importante cidade turística do norte maranhense.

Para que possa haver captação de parcela existente da água do rio Una, medições de vazões periódicas em diferentes épocas do ano, chuvosa e secas, se faz 
necessário para fins de estabelecer uma vazão de referência, determinado pela ANA (2011) como as vazões mínimas que garanta uma condição de água no manancial. A partir dessa condição, são realizados os cálculos de alocação da água, de modo que, quando essas vazões mínimas ocorram, os usuários ou os usos prioritários mantenham, de certa forma, suas retiradas de água.

Um exemplo usado como vazão de referência em outorgas é a $Q_{90}$, onde, para que se chegue em seu valor característico utilizado em outorga, precisaria de uma análise anual em diferentes épocas do ano, como já descrito (ANA, 2013), dessa forma, 13,43 $\mathrm{m}^{3}$ /s é considerada uma vazão instantânea, calculada em um período em que as chuvas na região estão mais frequentes, que poderia ser a vazão que poderia compor a $Q_{90}$ do rio Una. Porém, poucos estudos e trabalhos publicados sobre o assunto referente ao Una, limitam por exemplo, implantação de postos fluviométricos que poderiam realizar os trabalhos de medição de vazão para determinação da $\mathbf{Q}_{90}$.

Em um contexto social, o rio Una representa uma atração turística para o município de Morros - MA, nesse contexto, a PNRH estabelece também o uso da vazão ecológica, esta por sua vez, é a vazão que é exigida para que atenda o equilíbrio ambiental do rio. Porém, Silva (2003) destaca que um dos fatores que contribuíram para o potencial turístico do rio foi a grande divulgação do Bumba Boi de Morros, contudo, lançamentos de resíduos sólidos pelos visitantes e moradores que advinham das visitas contribuíram para o aumento da poluição antrópica e desgaste ambiental. 0 estudo da vazão se destaca mais uma vez, onde, por meio do poder público, dados como os levantados neste trabalho contribuem para a conscientização das pessoas que realizam as visitações no corpo hídrico além de que, contribuem para enriquecimento da literatura voltado ao rico senário fluviométrico maranhense.

Com a mensuração da vazão do rio Una e buscando contextualizar o debate do uso dá água, o trabalho conseguiu cumprir seus objetivos preestabelecidos. Ademais, houve, por meio deste, uma grande agregação para os estudos voltados ao assunto aqui abordado, haja vista a falta de trabalhos semelhantes a este, com tais resultados, não foram encontrados na literatura. 


\section{CONCLUSÕES}

Vale pontuar que o uso da água não se consolida somente por meio de uma única medida de vazão e, portanto, e imprescindível que mais estudos e análises a respeito do tema sejam implantados para a região. Além disso, compete ao poder público, implantações de estações fluviométricas e mais consideração com uma região rica em seu aspecto fluvial. Logo, o trabalho serviu como explanador de uma área pouco explorada no estado, que se vale de atenção para que se tenha prosseguimento e que possa somar para o conhecimento hidrológico do rio Una.

\section{REFERÊNCIAS}

AGÊNCIA NACIONAL DE ÁGUAS - ANA. Conjuntura Dos Recursos Hídricos no Brasil. Brasília. 2013. 432 p.

AGÊNCIA NACIONAL DE ÁGUAS - ANA. Conjuntura dos Recursos Hídricos no Brasil 2020. 2020. 129 p.

AGÊNCIA NACIONAL DE ÁGUAS - ANA. Cuidando das águas: soluções para melhorar a qualidade dos recursos hídricos. 2. ed. Brasília: ANA, 2011.

ANA (Brasil). Outorga de direito de uso de recursos hídricos / Agência Nacional de Águas. -- Brasília: SAG, 2011. 50 p.: il. -- Cadernos de capacitação em recursos hídricos; v.1 vol. 6

AGÊNCIA NACIONAL DE ÁGUAS - ANA (Brasil) Manual de procedimentos técnicos e administrativos de outorga de direito de uso de recursos hídricos 2013/ Agência Nacional de Águas - ANA, Brasília: 2013.

BEZERRA, J. C. F.; DIAS, J. G. S.; OLIVEIRA, A. T. de S.; RIBEIRO, A. T.; DANIEL, R. MEDIÇÃO DE VAZÃo EM UM CANAL FLUVIAL UTILIZANDO 0 MÉTODO DO FLUTUADOR. II Congresso Internacional das Ciências Agrárias COINTER - PDVAgro, 2017.

BONIFÁCIO, C. M; FREIRE, R. COMPARAÇÃO DE TRÊS MÉTODOS PARA A MEDIÇÃO DA VAZÃO E VELOCIDADE APLICADOS EM DOIS CURSOS D'ÁGUA DA BACIA DO RIBEIRÃO MARINGÁ. X Fórum Ambiental da Alta Paulista, v. 9, n. 2, 2013, pp. 406-415.

BRASIL. Lei Federal no 9.433, de 8 de janeiro de 1997. Cria o Sistema Nacional de Gerenciamento de Recursos Hídricos, regulamenta o inciso XIX do art. 21 da Constituição Federal, e altera o art. 1ํ da Lei no 8.001, de 13 de março de 1990, que modificou a Lei no 7.990, de 28 de dezembro de 1989.

CAPOZZOLI, C. R.; CARDOSO, A. de 0.; FERRAZ, S. E. T. Padrões de Variabilidade de Vazão de Rios nas Principais Bacias Brasileiras e Associação com 
Índices Climáticos. Revista Brasileira de Meteorologia, v. 32, n. 2, 243-254, 2017.

CARVALHO, Renei Rocha et al. MONITORAMENTO DA VAZÃO EM RIOS DA REGIÃO SUL DO AMAZONAS. Revista EDUCAmazônia, Humaitá - AM, v. XII, p. Pág. 827, 1 jun. 2014.

CBHSF. 0 que é vazão de um rio? 2016. Disponível em: https://cbhsaofrancisco.org.br/noticias/sustentabilidade_blog/o-que-evazao-de-um-rio. Acesso em: 20 de Jun. 2021.

GAMARO, P. E. M.; RODRIGUES, M; PETERSON, C. A.; LIMA, K. A. COMPARATIVO DO MEDIDOR DE VAZÃO ACÚSTICO FLOWTRACKER E MICRO MOLINETE. XVII Simpósio brasileiro de recursos hídricos, São Paulo - 2007.

IBGE. Cidade e Estados. Instituto Brasileiro de Geografia e Estatística (IBGE). Disponível em: < $\quad$ https://www.ibge.gov.br/cidades-eestados/ma/morros.html >. Acesso em: 05, jun. e 2021.

ISO 748. THIS STANDARD WAS LAST REVIEWED AND CONFIRMED IN 2013. THEREFORE THIS VERSION REMAINS CURRENT. Ed. 4, p. 46, 2007.

MARTINS, R. F. D. Alterações socioambientais na microbacia do rio Una-MA. In: XVII Encontro Nacional de Geógrafos, 2016, São Luís. Disponível em: <http://1467683352_ARQUIVO_ALTERACOESSOCIOAMBIENTAISNAMICR OBACIADORIOUNAEMMORROS.pdf (agb.org.br)> acesso em: 18 mai. 2021.

MEIRELES, Daniel. Morros: como chegar, o que fazer, onde ficar. O Imparcial, $2020 . \quad$ Disponível em: $<$ https://oimparcial.com.br/turismo/2020/03/moros-como-chegar-o-quefazer-onde-ficar/>. Acesso em: 05, jun. e 2021.

MINISTÉRIO DO MEIO AMBIENTE. Plano Nacional de Recursos Hídricos - síntese executiva. MMA, Secretaria de Recursos Hídricos. Brasília, 2006.

NÚCLEO GEOAMBIENTAL. Bacias hidrográficas e climatologia no Maranhão. São Luís, 2016. p.17. Disponível em: <https: //Relatório NUGEO (uema.br). acesso em: 18 mai. 2021.

PALHARES, J. C. P; RAMOS, C.; KLEIN, J. B.; LIMA, J. M. M. de; MULLER, S.; CESTONARO, T. Medição de Vazão em Rios pelo método do Flutuador. Comunicado Técnico 455, EMBRAPA. Concordia, SC. Versão Eletrônica, 2007.

PEDROSA, Valmir de Albuquerque. - Solução de conflitos pelo uso da água / Valmir de Albuquerque Pedrosa. - Serra, ES: 2017. - 109 p. Recursos hídricos - Água. 2. Diretrizes - Uso da água.

ROCHA, A. K. P.; FREIRE, A. dos S.; LEAL, L. de S. G.; SILVA, J. N. da; BARROS JUNIOR, G.; Determinação da vazão de águas correntes para uso em áreas de agricultura familiar no semiárido brasileiro. II Congresso Brasileiro das Ciências Agrárias COINTER - PDAgro, 2017. 
SILVA, B. M. B. da; SILVA, D. D. da; MOREIRA, M. C. Influência da sazonalidade das vazões nos critérios de outorga de uso da água: estudo de caso da bacia do rio Paraopeba. Ambiente e Água - An Interdisciplinary Journal of Applied Science, Vol. 16, n 3, 2015.

SILVA, S. C. O. BASTOS, J. H. M.; GONÇALVES, M. F. P.; FEITOSA, A. C. Alterações ambientais relacionadas ao desenvolvimento do turismo na bacia do rio Una -MA. In: X Simpósio Brasileiro de Geografia Física Aplicada, 2003, Rio de Janeiro.

SOUZA, A. P; CRUZ, M. R. A importância da água no ordenamento jurídico brasileiro. PublicaDireito, 2013. Disponível em: <http://www.publicadireito.com.br/artigos/?cod=56f9b1360d583668>. Acesso em: 09 de Jun. 2021.

SOUZA. M. R. S. A RELAÇÃO INTRÍNSECA ENTRE MEIO DE HOSPEDAGEM, LAZER E SUSTENTABILIDADE: o estudo de caso da Pousada Pedra Grande em Morros-MA. 2008, São Luís. Disponível em: $<$ https://https://www.google.com/url?sa=t\&rct=j\&q=\&esrc=s\&source=we $\mathrm{b} \& \mathrm{~cd}=\& \mathrm{cad}=$ rja\&uact $=8 \& \mathrm{ved}=2$ ahUKEwirzKHczuXwAhUPH7kGHZ9LA10Q FjACegQIChAD\&url=https\%3A\%2F\%2Fsigaa.ufma.br\%2Fsigaa\%2FverProd ucao\%3FidProducao\%3D964226\%26key\%3D9e515b12823459df02a0c50 91b48bbaf\&usg=AOvVaw0vPtYeojfOG8QsU7QCz6So. acesso em: 18 mai. 2021. 


\section{CAPÍTULO II}

\section{LEVANTAMENTO DE ÁREAS DESMATADAS NA AMAZÔNIA LEGAL MARANHENSE}

DOI: 10.51859/amplla.lar559.1121-2

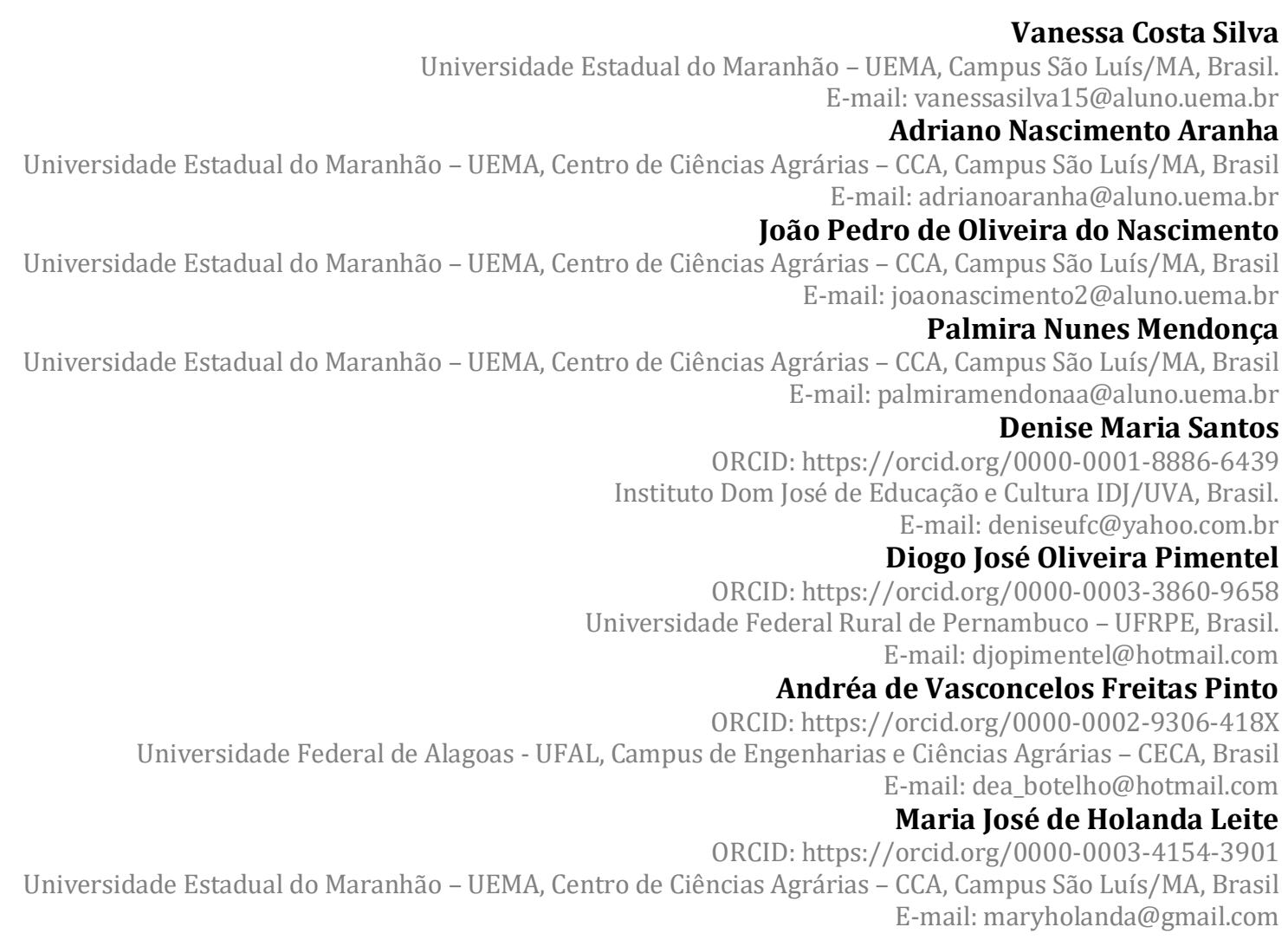

\section{RESUMO}

A Amazônia Legal é responsável por abrigar todo o bioma amazônico, além de uma porcentagem do Bioma Cerrado e do Pantanal Mato-Grossense. No Maranhão, a Amazônia Legal tem uma ocupação de $34 \%$ da região, porém vem sofrendo com o grande índice de desmatamento e queimadas, além da expansão agrícola no Sul do estado, portanto o trabalho visa fazer o levantamento dessas áreas desmatadas, identificando os municípios que mais influenciaram para essa problemática, assim como seus vetores e consequências. A metodologia abordada baseou-se na escolha de uma área de estudo totalizando 181 municípios presentes na Amazônia Legal, também foi feita a aquisição de dados através de pesquisas bibliográficas (textos, artigos e livros, resumos entre outros). Como resultados, identificamos a situação das áreas desmatadas, onde foi detectado 810 quilômetros quadrados desmatados na Amazônia Legal somente no mês de março de 2020 e, no mesmo mês do ano de 2021 , o estado do Pará foi responsável por 35\% e o estado do Mato Grosso por 25\% dos índices dos desmatamentos, tendo como principais causas o avanço da pecuária e a extração ilegal de madeira; já o Maranhão foi responsável por 6\% desses índices, 
apesar do estado ainda apresentar áreas bastantes degradadas, por isso, vale destacar a importância de ter áreas protegidas. Sobre o aumento dos desmatamentos, tivemos em destaque os municípios de Itinga do Maranhão, Arame, Bom Jardim, Açailândia e Bom Jesus das Selvas. Sendo que o município de Itinga do Maranhão ocupa em primeiro lugar há alguns anos com a maior taxa de incremento de desmatamento dentro da Amazônia Legal Maranhense causada pelo o avanço da monocultura da soja e plantação do eucalipto. As principais causas dos desmatamentos são a pecuária bovina, agricultura e exploração de madeira ilegal, tendo em vista que no Maranhão esses dados são totalmente influenciados pela pecuária onde se destacaram os municípios de Açailândia e Amarante do Maranhão com as maiores porcentagens de cabeças bovinas. A perda da biodiversidade, erosões dos solos, degradações de bacias hidrográficas e o efeito estufa são alguns dos principais impactos causados pelo desmatamento. Como conclusão, destacamos que o processo de desmatamento é causado por atividades produtivas que, na maioria das vezes, são executadas de forma ilegal, como por exemplo, a extração da madeira, por isso a necessidade de levantamentos técnicos, sobretudo, indispensavelmente, com a participação de engenheiros agrônomos, os quais são profissionais capazes de elaborar medidas técnicas capazes de minimizar esses problemas garantindo a preservação e sustentabilidade. Entretanto, as leis ambientais e as políticas públicas são fundamentais para que haja um embasamento jurídico garantindo a permanência de nossas florestas e dos nossos recursos. Vale ressaltar ainda que alternativas ecológicas como a implantação do sistema ILPF (Integração Lavoura Pecuária e Florestas) estão sendo adotadas como medidas capazes de reduzir a emissão de carbono na atmosfera, por isso, tem-se a necessidade de traçar medidas inteligentes e manter nossas áreas protegidas, além da atuação efetiva do novo código florestal garantindo o uso racional desses recursos naturais.

Palavras-chave: Desmatamento; monitoramento; gases de efeito estufa; agropecuária.

\section{INTRODUÇÃO}

A Amazônia Legal é uma área bem extensa, onde abriga todo o bioma Amazônia, contendo ainda 20\% do bioma Cerrado e algumas partes do Pantanal mato-grossense, o que garante uma ampla diversidade de paisagens (ECO, 2014). No Maranhão, a área de Amazônia legal ocupa cerca de 34\% do estado, possui um número reduzido de ocupação do espaço com áreas protegidas e, além disso, vem sendo ameaçada ao longo dos anos devido à fatores como o alto índice de desmatamento, queimadas, extração de madeira, abertura de áreas agrícolas, entre outros (MIOTTO, 2012).

A vegetação é o constituinte principal da biota e a sua preservação é essencial para as espécies presentes na natureza e para a população humana. É importante 
salientar que no processo de ocupação da Amazônia Maranhense, a principal ação antrópica que promove a degradação ambiental é o desmatamento, sendo este considerado um dos vetores que mais contribuem para a alteração da fitofisionomia dessa área. Ao longo dos anos, as atividades econômicas que envolvem a extração dos recursos naturais da Amazônia Legal vêm contribuindo de forma significativa para a degradação da fauna e flora nessa região. Apesar da redução do desmatamento na Amazônia brasileira ao longo dos anos, sabe-se ainda pouquíssimo sobre a contribuição do estado do Maranhão em relação a tal causa, possuindo poucos estudos que retratam sobre o assunto. (SILVA et al 2019).

É importante frisar que o desmatamento contribui de forma relevante para a perda da biodiversidade, além de devastar os recursos naturais, e esse agravante acarreta impactos consideráveis comprometendo o equilíbrio do planeta em questões como a diminuição dos recursos hídricos, desertificação, alterações climáticas, extinção de espécies de animais e vegetais, entre outros (IMESC, 2020). Embora toda a área da Amazônia Legal seja de suma importância, principalmente em relação aos serviços ecossistêmicos, a preservação da biodiversidade e a regulação do clima da região, é notável que durante todo o processo de ocupação que vem ocorrendo ao longo dos anos não contribuiu para a sua preservação (MAURANO et al, 2019).

Considerando a grande diminuição desse bioma no Estado do Maranhão e a ampla perda com a biodiversidade de espécies, a escolha de nossa pesquisa baseiase em mostrar de forma científica a importância da preservação ambiental para a manutenção do meio ambiente regional, nacional e mundial. Vale ressaltar, que a Amazônia maranhense possui uma rica biodiversidade, ocupa $26 \%$ do bioma amazônico e atualmente requer atenção especial para continuar existindo devido ao alto desmatamento desse bioma nos municípios maranhenses em que a mesma está presente.

Assim, nossa pesquisa teve como principal objetivo, desenvolver um levantamento de dados sobre as áreas degradadas no bioma Amazônia Legal no estado do Maranhão, procurando identificar os municípios que mais sofreram desmatamentos nos últimos anos, os vetores que estão contribuindo para esse desmatamento e os impactos desse desmatamento. 


\section{METODOLOGIA}

\section{1. Área de estudo}

A área de estudo corresponde a porção ocidental da Amazônia Maranhense mais parte do bioma cerrado, também conhecida como Amazônia Legal maranhense, assim totalizante 181 municípios que compõem essa área, assim podemos observar abaixo na figura 1 a área que abrange a Amazônia Legal maranhense.

Vale ressaltar que o Maranhão é o único estado abrangido parcialmente e que os 181 municípios presentes na Amazônia legal correspondem a uma área total de $276419,841 \mathrm{Km}^{2}$, sendo 21 municípios que estão parcialmente integrados na Amazônia Legal.

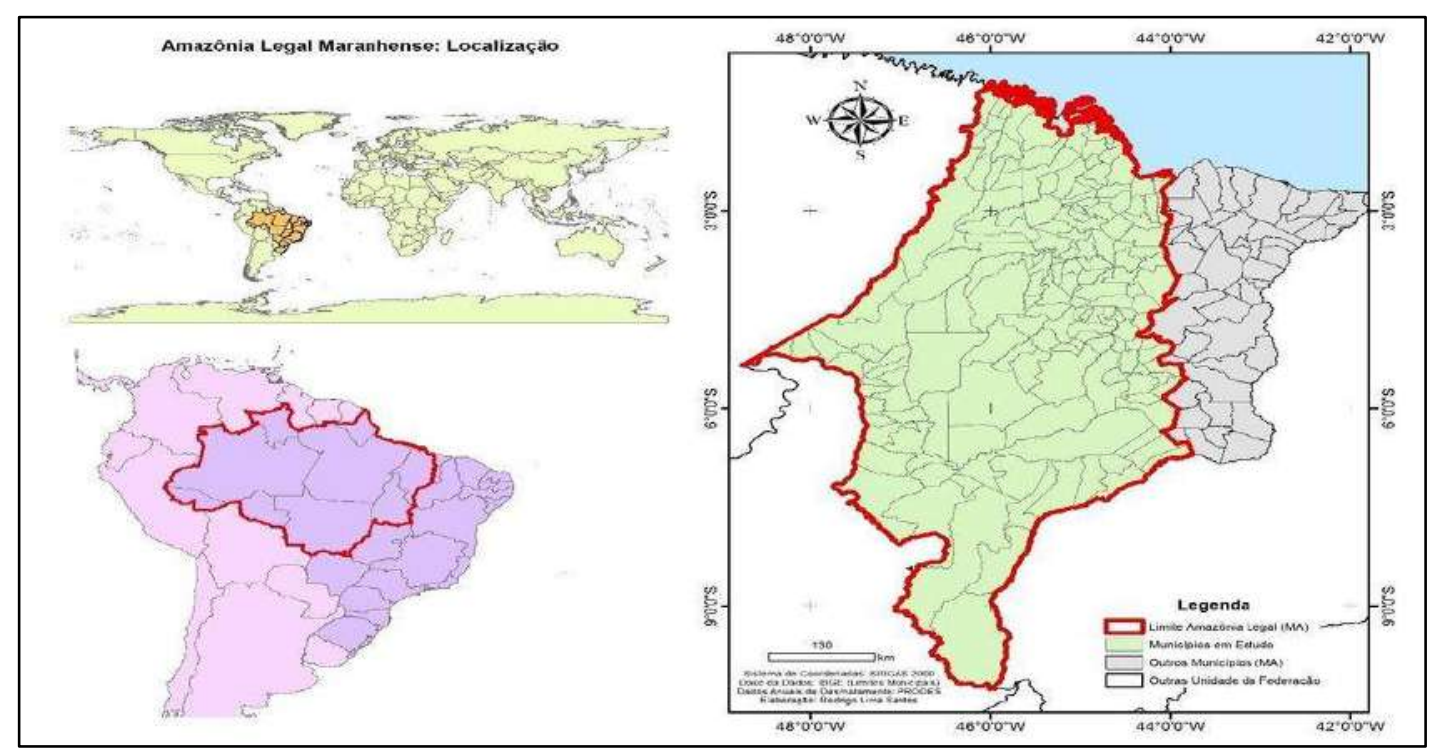

Figura 1. Mapa de Localização da área de estudo.

Organizado por SANTOS; NUNES (2017). Fonte: IBGE (2017).

A divisão política do Maranhão conta atualmente com 217 municípios, distribuídos em cinco mesorregiões geográficas - Norte Maranhense, Leste Maranhense, Oeste Maranhense, Centro Maranhense e Sul Maranhense (SPINELLIARAUJO et al., 2016, p.13) (Figura 2).

0 estado maranhense apresenta $1,1 \%$ do seu território no bioma Caatinga com 15 municípios, 64,1\% no Cerrado com 138 e 34,8\% no bioma Amazônia com 
110 municípios associados a esse bioma, sendo 209 municípios inseridos em área de Amazônia Legal (Figura 3).

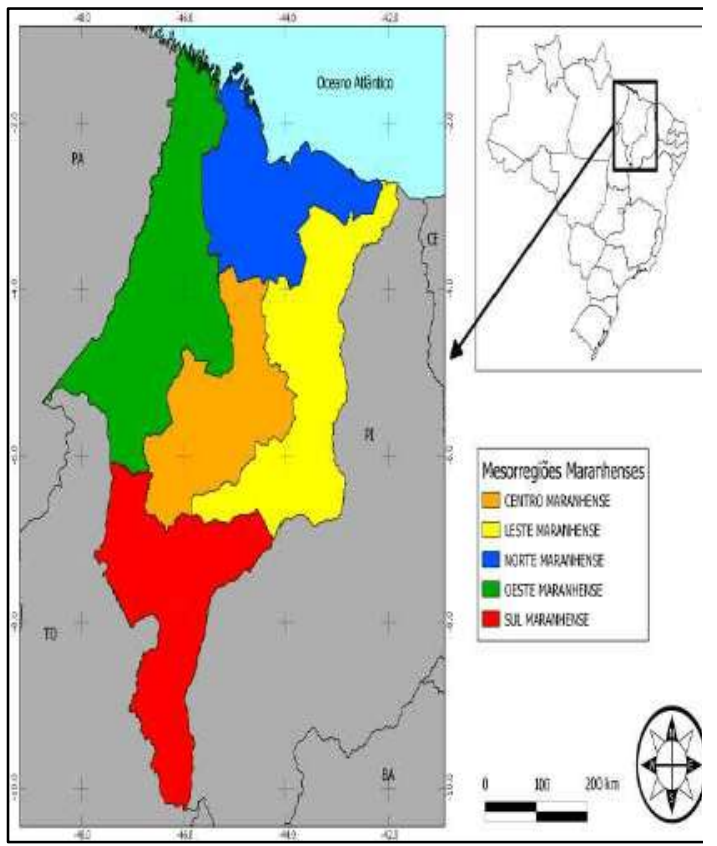

Figura 2. Localização do estado do Maranhão com suas mesorregiões.

Fonte: IBGE (2016).

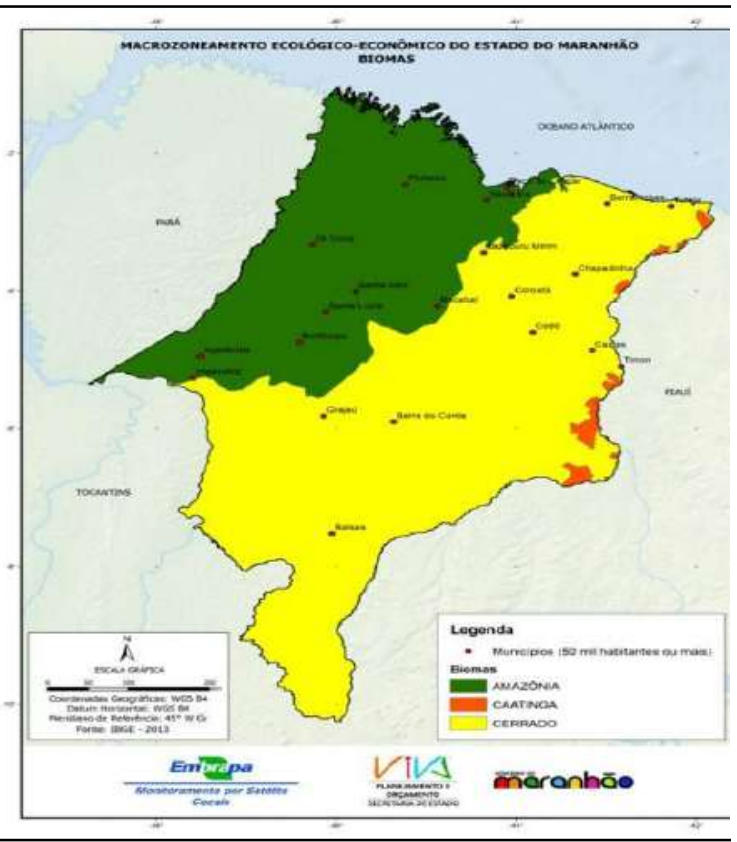

Figura 3. Biomas no estado do Maranhão.

Fonte: NuGeo - UEMA (2013).

Segundo o IBGE (2020), a Amazônia Legal corresponde à área de atuação da Superintendência de Desenvolvimento da Amazônia - SUDAM delimitada no Art. $2^{\circ}$ da Lei Complementar n. 124, de 03.01.2007. Essa região é composta por nove estados brasileiros que são Rondônia, Acre, Amazonas, Roraima, Pará, Amapá, Tocantins, Mato Grosso e o Maranhão (a oeste do Meridiano 44ํㅜ).

De acordo com o IMESC (2020, p. 79), os tipos de vegetação com maior representação no território do Bioma Amazônico Maranhense foram Vegetação secundária com palmeiras, com 34.064,42km2 (29,74\%), Pastagem e Vegetação secundária com palmeiras, com 33.839,02km2 (29,54\%); Formação Pioneira com Influência Fluviomarinha arbórea (5.550,97km2, 4,85\%), Floresta Ombrófila Densa Terras Baixas e Vegetação Secundária sem palmeiras $(5.457,96 \mathrm{~km} 2,4,77 \%)$, Formação Pioneira com Influência Fluvial/Lacustre herbáceae $(4.877,65 \mathrm{~km} 2$, 4,26\%), Floresta Estacional Semidecidual submontana $(3.537,44 \mathrm{~km} 2,3,09 \%)$ e Vegetação Secundária com palmeiras e Agricultura com culturas cíclicas (2.916,67km2, 2,55\%) (Figura 4). 


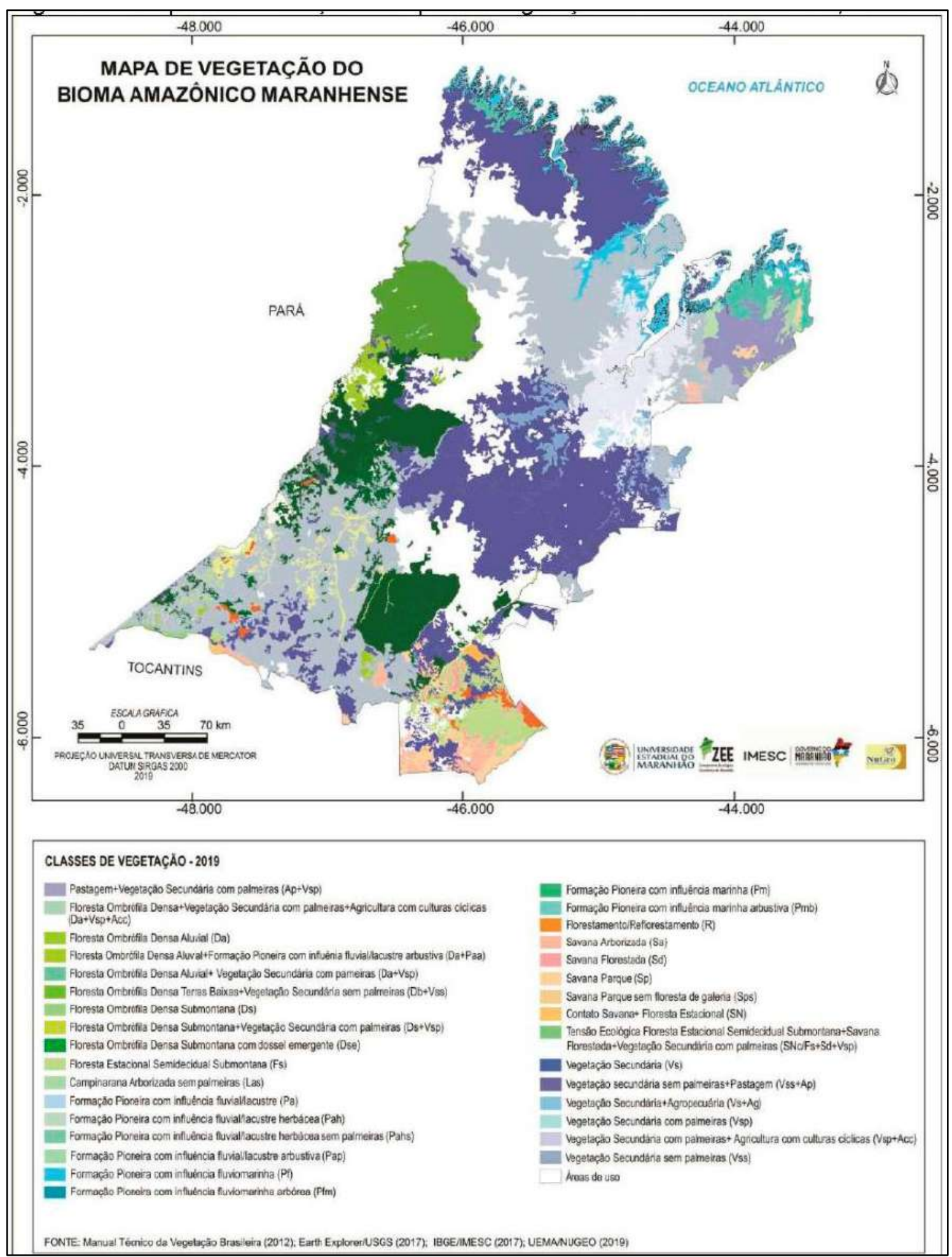

Figura 4. Mapa de distribuição dos tipos de vegetação do Bioma Amazônico, ZEE/MA.

Fonte: Manual Técnico da Vegetação Brasileira (2012).

Segundo Koppen (apud SILVA et al., 2019, p. 445), o clima na Amazônia Legal é caracterizado em equatorial e tropical, sendo que nos estados do Amazonas, Pará, Acre, Rondônia, Amapá, norte do Mato Grosso e oeste de Roraima predomina-se o 
clima equatorial, que é marcado durante todo ano por alta umidade e elevadas temperaturas. Já o clima tropical é constatado no Centro e Sul do Mato Grosso, em Tocantins e ao leste de Roraima, com temperaturas em médias de $20^{\circ} \mathrm{C}$ e amplitudes que não excedem $10^{\circ} \mathrm{C}$ (ASSAD, 2016 apud SILVA et al., 2019, p. 445).

Já em relação ao clima na Amazônia Legal Maranhense, a mesma é composta por três unidades climáticas, as quais podem-se observar na figura 5.

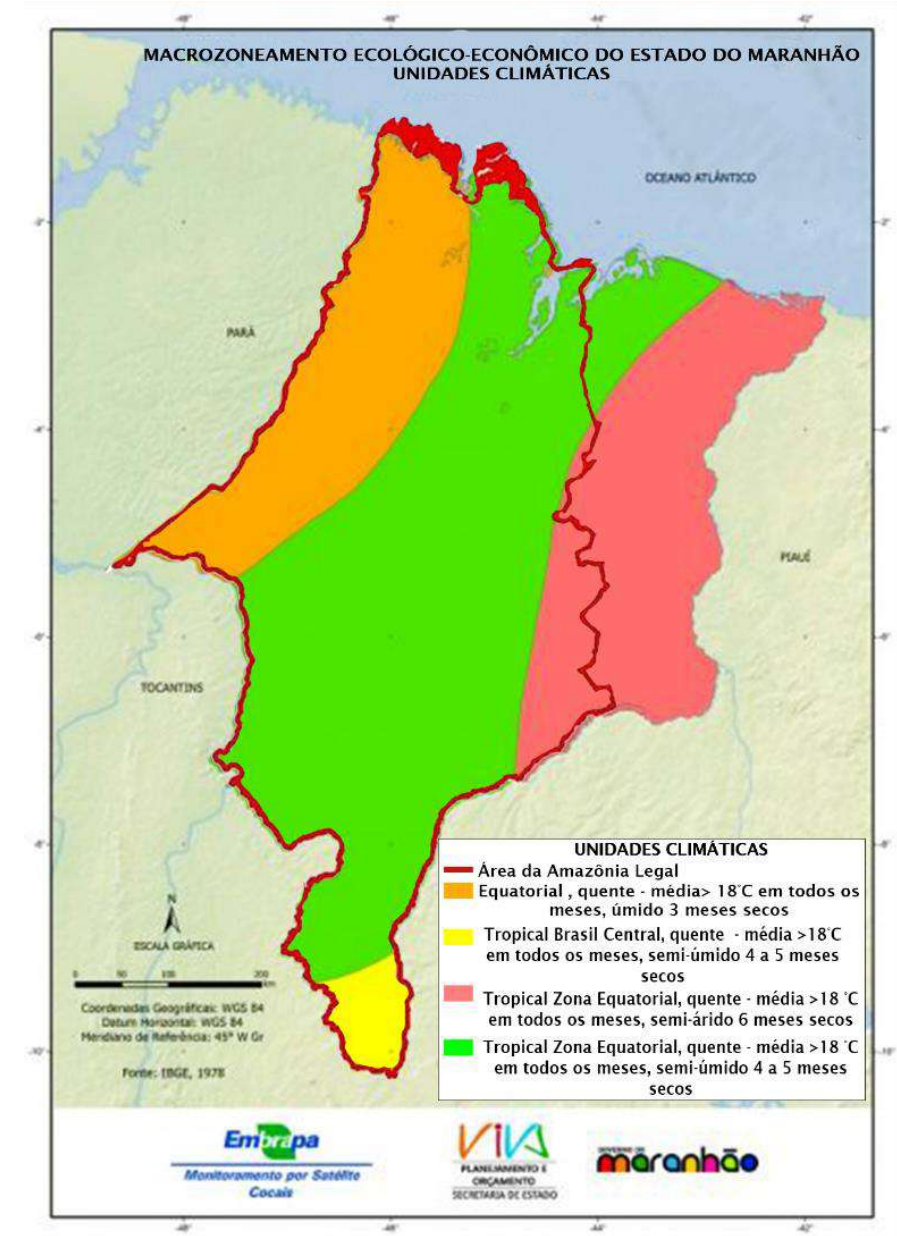

Figura 5. Mapa de distribuição dos tipos de vegetação do Bioma Amazônico, ZEE/MA Adaptada por Silva (2021) Fonte: Bem/rapa (2013)

Vale ressaltar que a população da Amazônia Legal aumentou de 8,2 milhões em 1972 para 28,1 milhões de habitantes em 2020, o que representa 13\% da população brasileira. A densidade demográfica na região é ainda baixa: 5,6 habitantes por $\mathrm{km}^{2}$. Em relação aos estados, o Pará é o mais populoso, com 8,8 milhões, seguido por Maranhão (5,9 milhões) e Amazonas (4,2 milhões). Por outro lado, o Amapá (862 mil) e Roraima (631 mil) são os estados menos populosos na 
região. 0 Produto Interno Bruto (PIB) real da Amazônia Legal totalizou R\$ 613,3 bilhões em 2018, o que representa apenas 8,7\% do PIB do Brasil (SANTOS; SALOMÃO; VERÍSSIMO, 2021).

\subsection{Aquísição de dados}

A aquisição dos dados foi obtida por meio de fontes secundárias por meio do site do IBGE (Instituto Brasileiro de Geografia e Estatística), PRODES (Projeto de Monitoramento do Desmatamento na Amazônia Legal por Satélite), INPE (Instituto Nacional de Pesquisas Espaciais), IMAZON (Instituto do Homem e Meio Ambiente da Amazônia) e TerraBrasilis, além de sites do Governo do Maranhão, SEMA (Secretaria Estadual do Meio Ambiente e Infraestrutura), G1.COM (GLOBO), os quais, juntamente com outros trabalhos, nos forneceram dados necessários para a obtenção dos nossos resultados.

Além disso, para complementação na elaboração deste trabalho, utilizou-se várias pesquisas bibliográficas consideradas indispensáveis e de extrema importância para o tema em questão, com a finalidade de investigar previamente os elementos que poderiam dar uma visão mais ampla sobre o assunto. Então, segundo o autor Bento (2012, p. 42) a revisão da literatura é uma parte vital do processo de investigação. Aquela envolve localizar, analisar, sintetizar e interpretar a investigação prévia (revistas científicas, livros, actas de congressos, resumos, etc.) relacionada com a sua área de estudo; é, então, uma análise bibliográfica pormenorizada, referente aos trabalhos já publicados sobre o tema. A revisão da literatura é indispensável não somente para definir bem o problema, mas também para obter uma ideia precisa sobre o estado atual dos conhecimentos acerca de um dado tema, as suas lacunas e a contribuição da investigação para o desenvolvimento do conhecimento.

Assim, a pesquisa bibliográfica consiste basicamente na coleta de informações por meio de textos, artigos, livros, dentre outros materiais de cunho científico. Desta forma, os dados serviram de embasamento para o desenvolvimento do assunto em questão, o qual trata-se de um método teórico focado em analisar os ângulos distintos que um mesmo problema pode ter, por isso, foram consultados autores com diferentes pontos de vista sobre um mesmo assunto. 


\section{RESULTADOS E DISCUSSÃO}

\subsection{Situação atual das áreas desmatadas na Amazônia Legal Maranhense}

Segundo pesquisas realizadas, em março de 2021, o SAD (Sistema de Alerta de Desmatamento) detectou 810 quilômetros quadrados de desmatamento na Amazônia Legal, um aumento de 216\% em relação a março de 2020, quando o desmatamento somou 256 quilômetros quadrados. 0 desmatamento detectado em março de 2021 ocorreu no Pará (35\%), Mato Grosso (25\%), Amazonas (12\%), Rondônia (11\%), Roraima (8\%), Maranhão (6\%), Acre (2\%) e Tocantins (1\%) (FONSECA et al., 2021) (Figura 6).

Os dados apresentados na figura 6 demonstram que os estados que apresentaram os maiores índices de desmatamento da Amazônia Legal foram Pará e Mato Grosso, pois, de acordo com pesquisas realizadas, esse crescimento dá-se principalmente por conta da extração ilegal de madeira e a pecuária devido à alta rentabilidade, sendo estas as principais atividades econômicas dessas regiões.

Já os estados como o Maranhão, Acre e Tocantins, demostraram as menores taxas, que, juntos representam $9 \%$ do desmatamento constatados nesse período. Vale ressaltar que de acordo com o SAD, no período desse levantamento, a maior parte das áreas desmatadas aconteceram em espaços privados, correspondendo a $65 \%$, e o restante está relacionado diretamente aos Assentamentos (22\%), às Unidades de Conservação (11\%) e às Terras Indígenas (1\%). 


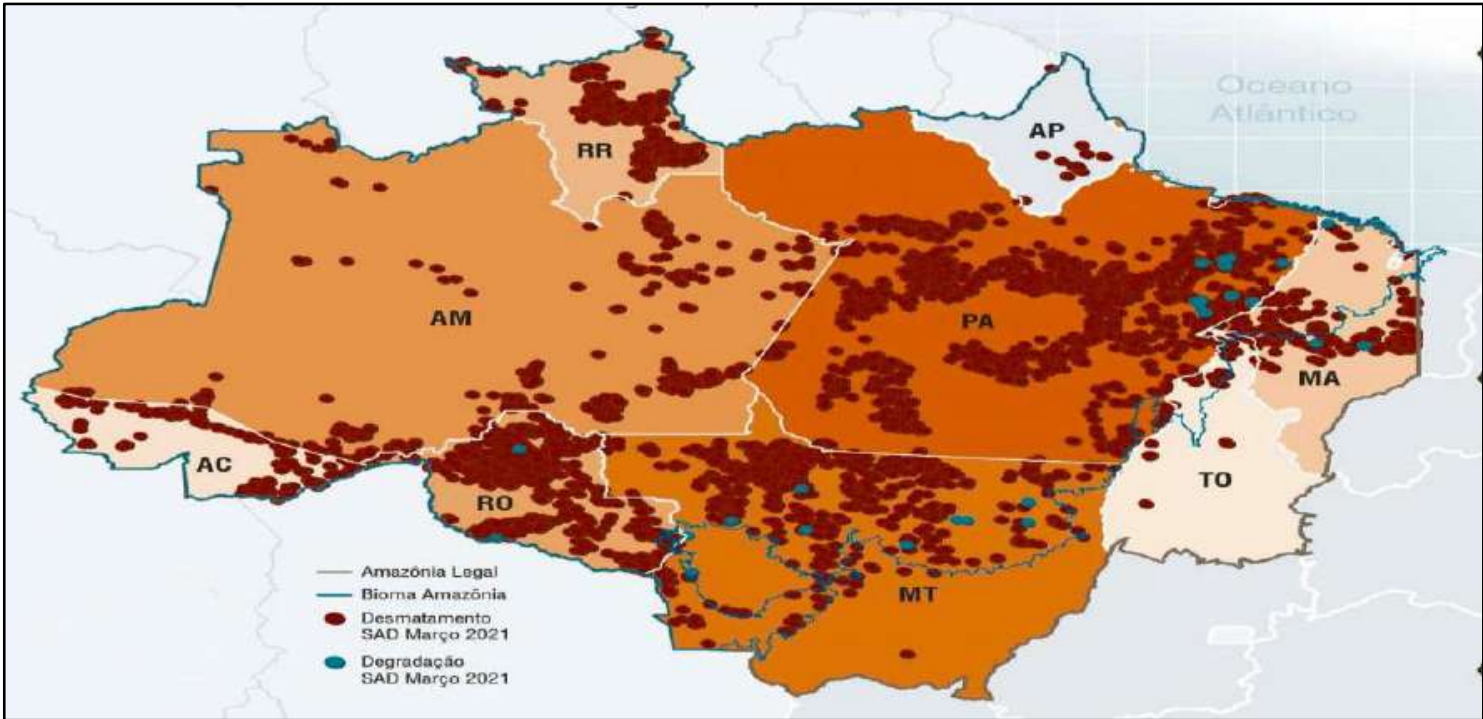

Figura 6. Mapa da área da Amazônia Legal.

Fonte: SAD (2021).

De acordo com Rebelo (2010), a nova Lei no 12.651 que substituiu o antigo Código Florestal acabou flexibilizando ainda mais as regras de proteção ambiental, o que auxiliou ainda mais a facilitação da regularização fundiária, além de aumentar as áreas permitidas para o uso da produção agropecuária. Assim, pode-se dizer que apesar do Maranhão apresentar uma área bastante desmatada, ainda é considerável se compararmos com o Pará, o qual lidera o ranking em primeiro lugar como sendo o estado que mais desmatou a área da Amazônia legal.

Com foco no estado do Maranhão, abaixo pode-se observar uma análise temporal do desmatamento no estado desde 2000 até o ano de 2020 (Figura 7), e constata-se que de 2000 até 2008 as taxas de incremento de desmatamento oscilaram, tendo seu maior pico em 2008, o qual apresentou uma área desmatada de $1271 \mathrm{Km}^{2}$. Já a partir de 2009 até 2020 observa-se que apesar de ainda apresentar desmatamentos na Amazônia legal, os valores ficam na média de 200 a 400 para o desmatamento, sendo que entre 2018 e 2019, houve uma redução de 15\% de áreas desmatadas.

Vale destacar que em 14 de abril de 2011 foi instituído um plano de ação conhecido como PPCD-MA (Plano de Ação para a Prevenção e o Controle do Desmatamento e das Queimadas no Estado do Maranhão), no intuito de prevenir e controlar o desmatamento, as queimadas e os incêndios florestais. Assim, desde então, pode-se perceber uma redução nas áreas desmatas até o ano de 2020, o qual 


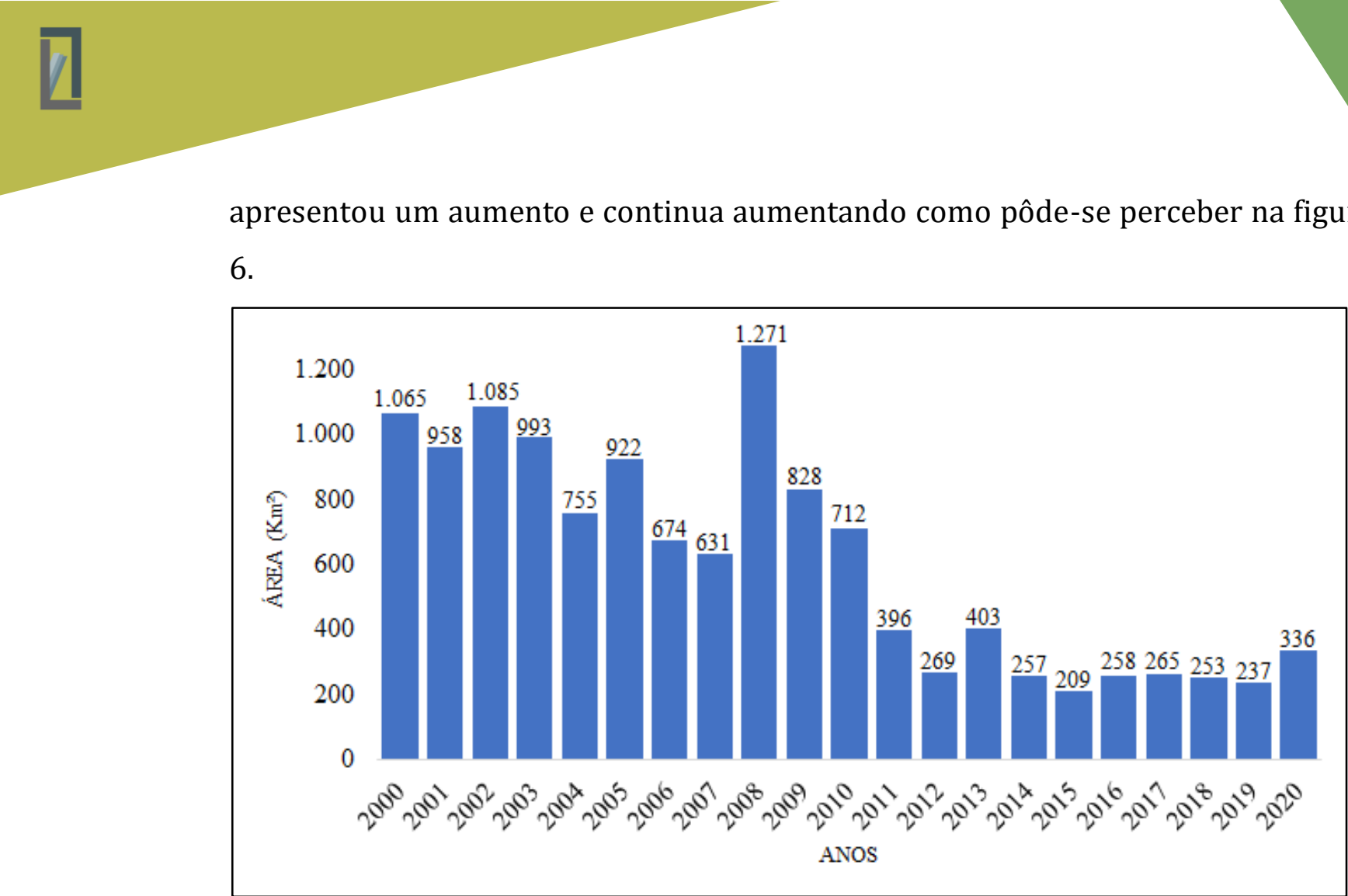

Figura 7. Taxas de desmatamento acumulados anualmente na Amazônia Legal (2000/2020).

Organizado por Silva (2021) Fonte: TERRABRASILIS (2020).

Entre os municípios que apresentaram maiores aumentos de desmatamento no último ano de 2020, teve como destaque os municípios de Itinga do Maranhão (22.877), Arame (22.375), Bom Jardim (20.591), Açailândia (19.970) e Bom Jesus das Selvas (12.072) (Figura 8). Vale ressaltar que esses municípios que apresentaram os maiores níveis de desmatamento no ano de 2020, também permaneceram nas mesmas posições em relação ao aumento da taxa de desmatamento nos últimos anos. É importante salientar que esses mesmos municípios apresentam as maiores áreas territoriais em relação as demais que tiveram índices inferiores de desmatamento. Desta forma, Silva et al (2019), relatam que os municípios que detém as maiores áreas territoriais também são os que mais desmatam.

Nos últimos anos, o município de Itinga do Maranhão vem permanecendo na primeira posição como taxa de incremento de desmatamento da Amazônia Legal e um dos principais motivos de isto estar ocorrendo, é o avanço da monocultura de soja e eucalipto na região. E segundo Antoniazzi (2018), o desmatamento da floresta para a implantação da monocultura causa grandes problemas ambientais nessas regiões e pode causar ainda o aumento de infestação de pragas nos cultivos, e se isso 
acontecer vai ser inevitável a aplicação de agrotóxicos e, consequentemente, vai ter a contaminação dos solos e do lençol freático.

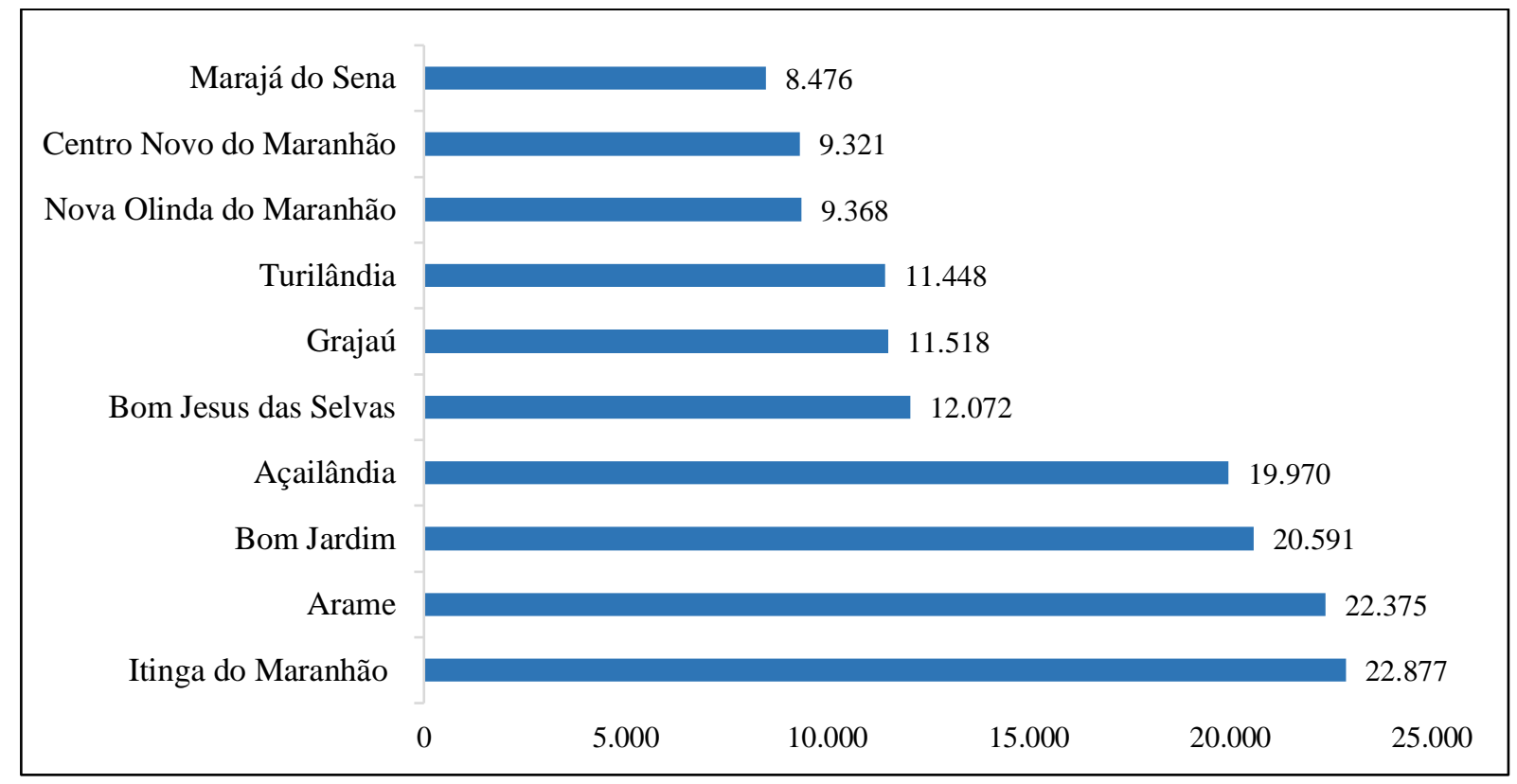

Figura 8. Municípios com maiores incrementos de desmatamento em 2020 na Amazônia Legal maranhense.

Organizado por Nascimento (2021) Fonte: PRODES (2020).

De acordo com os levantamentos abordados nesse trabalho, os principais vetores do desmatamento da Amazônia Legal Maranhense são: pecuária bovina, agricultura e a exploração ilegal de madeiras. Na tabela 1 apresenta-se dados dos números de cabeças bovinas e áreas plantadas por município conforme o censo agropecuário de 2017.

Conforme os dados apresentados na tabela acima, destacam-se os municípios de Açailândia e Amarante do Maranhão com os maiores índices de cabeças bovinas, ou seja, o índice de áreas desmatadas está diretamente ligado ao crescimento das áreas de pastagem. Contudo, é importante ressaltar a pecuária e sua relação com o novo código florestal.

O novo código florestal aprovado em 25 de maio de 2012, determina que na Amazônia, em área de floresta seja mantido 80\% como reserva legal (RL), nas áreas de cerrado 35\% e nos campos gerais 20\%. No restante do país a área de floresta a ser mantida como RL é de 20\% (SILVA; MARQUES; SAMBUICHI, 2016).

Segundo Alvim (2017) o novo código florestal veio para substituir o antigo código de 1965, sendo para ele uma lei que "não pegou" por causa de um fator muito 
importante que foi a fiscalização ineficiente, ou seja, o desmatamento da floresta permaneceu de forma cada vez mais crescente, principalmente, na Amazônia, por isso houve a necessidade de uma reforma na lei, além disso essa nova atualização teve um importante aliado que foi o Cadastro Ambiental Rural.

Tabela 1. População estimada das cabeças de bovinos e áreas plantadas na Amazônia Legal maranhense em 2017.

\begin{tabular}{ccc}
\hline MUNICíPIO & $\begin{array}{c}\text { BOVINOS } \\
\text { (cabeças) }\end{array}$ & Área Plantada (ha) \\
\hline Açailândia & 323636 & 27137 \\
Amarante do Maranhão & 262724 & 3885 \\
Barra do Corda & 129077 & 10925 \\
Bom Jardim & 160491 & 13328 \\
Bom Jesus das Selvas & 127856 & 8113 \\
Buriticupu & 138520 & 20260 \\
Centro Novo do Maranhão & 90608 & 3137 \\
Itinga do Maranhão & 106549 & 13933 \\
Santa Luzia & 231658 & 16755 \\
Zé Doca & 135189 & 6124 \\
\hline
\end{tabular}
Organizado por Nascimento (2021) Fonte: IBGE (2017)

Vale destacar que a grande ideia é que com o novo código florestal a lei seja de fato efetiva e cumprida, porém o mesmo código consta que o passivo ambiental existente até o período de 22 de julho de 2008 seja perdoado, o problema estar nesse quesito, pois em virtude desse perdão obviamente muitas propriedades não estarão preocupadas em recompor a mata, floresta e etc. Outra questão a ser debatida é que a pecuária na Amazônia é desenvolvida em área de floresta na maioria das propriedades onde deve-se preservar $80 \%$ da reserva legal, portanto, deveremos entender e discutir ainda mais sobre a produção e crescimento bovino em apenas $20 \%$ da área.

\subsection{Impactos do Desmatamento}

Apesar de que o desmatamento da Amazônia Legal maranhense teve uma redução nos últimos 16 anos, ainda é preciso trabalhos no desenvolvimento sustentável na agropecuária. E, além disso, é preciso fortalecer a fiscalização ambiental em territórios que têm fortes riscos de impactos ambientais, relacionados ao desmatamento (SILVA et al, 2019). 
O desmatamento causa a perda da biodiversidade, erosão dos solos, degradação das áreas das bacias hidrográficas, liberação de gás carbônico para atmosfera que é um dos gases do efeito estufa, redução da umidade do ar e o desequilíbrio social e econômico (PIACENTINI, 2012).

Em relação as emissões totais de Gases de Efeito Estufa (GEEs), elas atingiram 1,14 gigatons de $\mathrm{CO}_{2} \mathrm{e}^{7}$ na Amazônia Legal em 2019. Desse total, 76\% foram relacionados à mudança no uso da terra (principalmente desmatamento e queimadas). As emissões de GEEs da Amazônia tiveram seu menor valor em 2010 (656,1 megatons de C02e), mantiveram-se estáveis até 2012 (688,2 megatons de CO2e) e atingiram maior quantidade em 2019, quase o dobro de 2010 (SANTOS; SALOMÃO; VERÍSSIMO, 2021, p. 3), na tabela 2 pode-se observar a Emissão e Remoção de GEE nos Estados da Amazônia Legal no ano de 2019.

Como demonstrado, observa-se que o Estado Maranhão foi responsável por produzir 81,56 de megaton de dióxido de carbono $\left(\mathrm{CO}_{2}\right)$, porém houve uma redução de 24,03 megaton de $\mathrm{CO}_{2}$, isso devido a um efeito natural que é chamado de sequestro de carbono. Mesmo com essa remoção, ainda houve um saldo de 57,53 de megaton de $\mathrm{CO}_{2}$ na atmosfera agravando mais ainda o aquecimento global. Isto está acontecendo devido ao aumento de desmatamento na Amazônia legal maranhense para a expansão de cultivos agrícolas mais, precisamente, no cultivo de soja e eucalipto e, além da implantação de pasto para criação de bovinos. Desta forma, o setor agropecuário é um dos responsáveis na emissão dos gases do efeito estufa (GEE).

Com o desmatamento oriundo do setor, além de favorecer a emissão do GEE, por outro lado vem agravando outros problemas, como por exemplo, as erosões e desertificações nos solos, ocorrendo porque o mesmo fica exposto há várias intempéries como a chuva ou até mesmo a escassez, que diretamente vai favorecer o aumento do GEE. 
Tabela 2. Emissão e Remoção de GEE nos Estados da Amazônia Legal em 2019

\begin{tabular}{cccc}
\hline Estados & Emissão & Remoção & Total \\
\hline Acre & 39,62 & $-12,99$ & 26,62 \\
Amapá & 18,38 & $-17,87$ & 0,51 \\
Amazonas & 148,33 & $-146,42$ & 1,91 \\
Maranhão & 81,56 & $-24,03$ & 57,53 \\
Mato Grosso & 230,23 & $-43,70$ & 186,53 \\
Pará & 400,59 & $-150,65$ & 249,94 \\
Rondônia & 118,87 & $-19,64$ & 99,22 \\
Roraima & 67,07 & $-25,93$ & 41,15 \\
Tocantins & 32,48 & $-13,84$ & 18,64 \\
\hline Amazônia Legal & $1.137,13$ & $-455,08$ & 682,05 \\
\hline
\end{tabular}

Fonte: com base nos dados do SEEG (2019)

No que diz respeito à série histórica, as emissões de GEE na Amazônia Legal aumentaram na última década (SANTOS; SALOMÃO; VERÍSSIMO, 2021). Esse aumento ocorreu principalmente no setor mudança no uso da terra, influenciada pelo desmatamento e queimadas na região. As emissões desse setor subiram de 433 megaton CO2 e em 2010 para 864 megaton em 2019 (Figura 9). Além disso, houve aumento nas emissões dos outros segmentos, principalmente agropecuária.

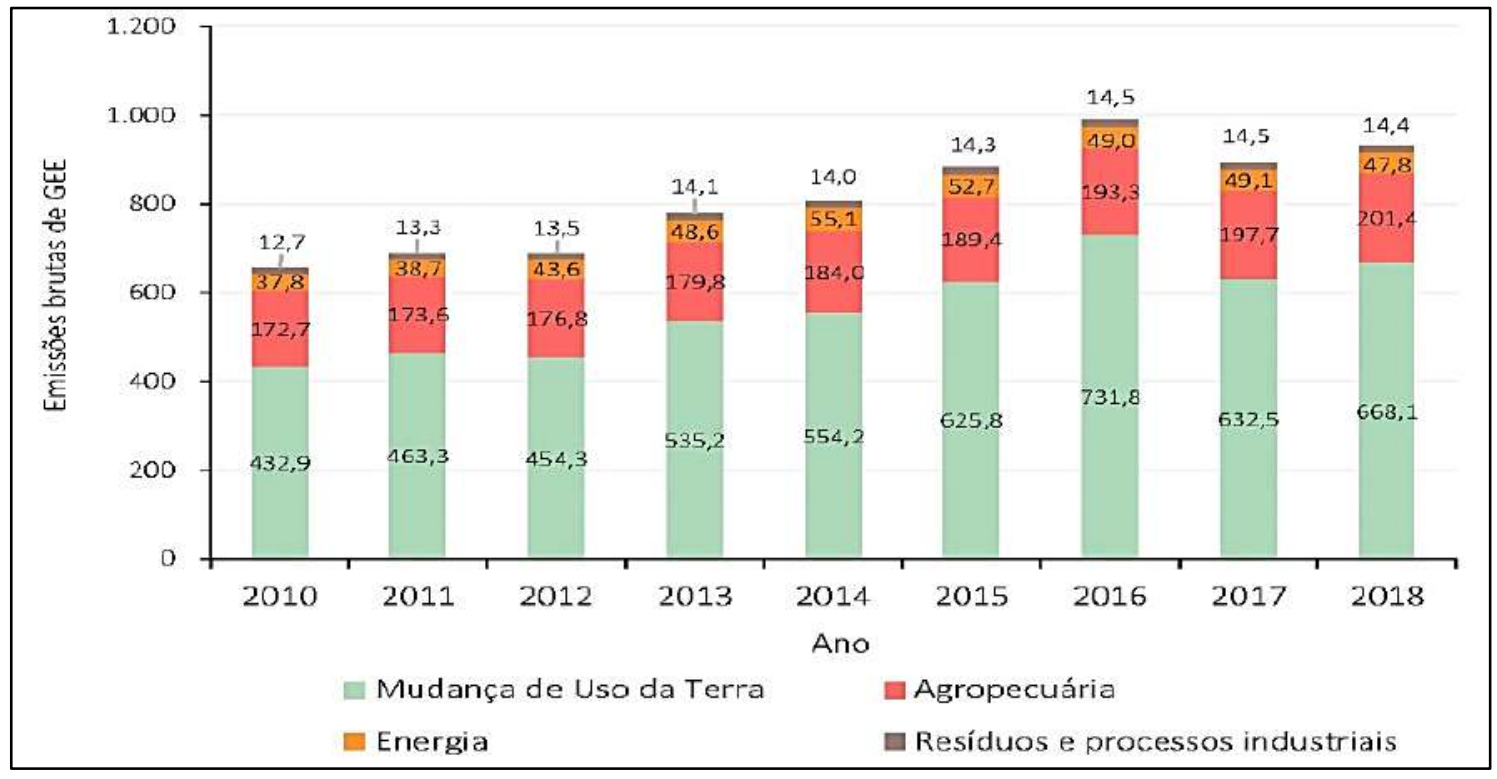

Figura 9. Estimativa de Emissões de GEE na Amazônia Legal, 2010-2019.

Fonte: com base nos dados do SEEG (2019).

Sabe-se que a mudança de uso da Terra (desmatamento e queimadas) é o vetor que mais proporciona a emissão de gases de efeitos estufa, principalmente no ano de 2016. A agropecuária, na sua vez, podemos perceber que no último ano houve um aumento das emissões de GEE em relação a esse vetor, isso porque a cada ano a 
agricultura e pecuária vem ganhando destaque. Assim, visando diminuir a emissão desses gases de efeito estufa, vem sendo realizados estudos para aplicação de medidas de mitigação desses gases no Brasil. Vale destacar que, de acordo com os dados do G1, os municípios do Maranhão que apresentaram maior emissão de GEE até abril de 2021 foram os que estão apresentados na figura 10 .

Pode-se perceber que seis dos municípios que estão presentes na figura 10, também se encontram na figura 8 como os municípios com maiores incrementos no desmatamento na Amazônia Legal no ano de 2020 que são: Itinga do Maranhão, Centro Novo do Maranhão, Bom Jesus das Selvas, Açailândia, Bom Jardim e Arame.

Assim, com a diminuição da biodiversidade na região da Amazônia Legal, um dos principais problemas que pode acontecer com esses ecossistemas naturais é a extinção de espécies endêmicas, ou até mesmo espécies ainda não identificadas por pesquisadores (ISPN, 2019).

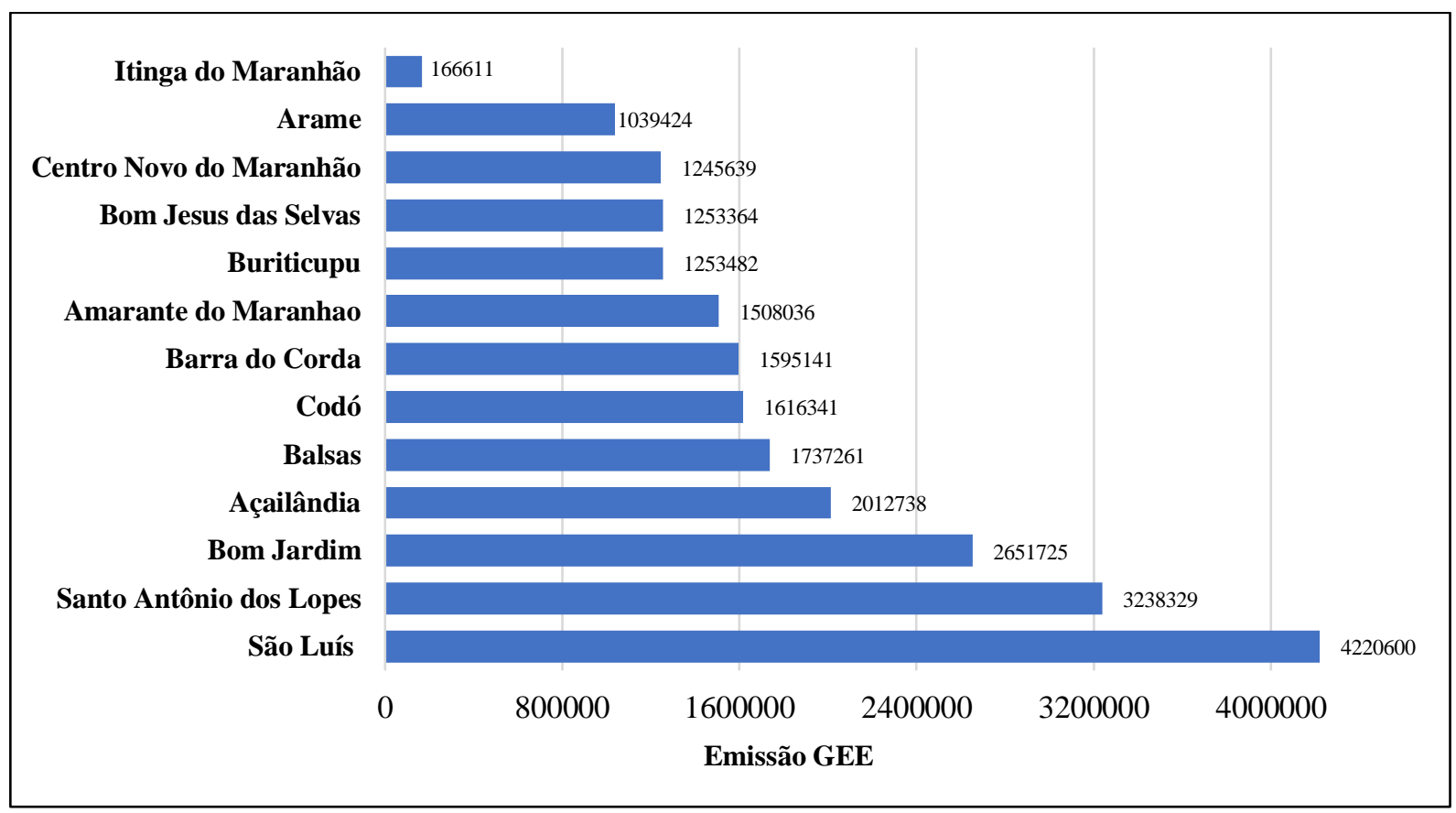

Figura 10. Municípios com mais emitiram gases de efeito estufa até abril de 2021. Produzido e Organizado por Silva (2021) Fonte: G1.COM (2021).

Nos últimos 70 anos, o Maranhão teve uma perda bem significativa de $80 \%$ da floresta amazônica. Além disso, as cinco maiores cidades maranhenses que contém o bioma amazônico, vem apresentando perda da biodiversidade, e isso vai causar mudanças climáticas e comprometimento na qualidade de vida da população (G1, 2019). 
Tendo em vista que a agricultura é um dos vetores responsáveis pelo grande índice de desmatamento nos últimos anos, esse vetor vem ocasionando mudanças do uso do solo, que é conduzida sobre a intensificação e expansão dessas áreas para o cultivo agrícola, e isso vai favorecer nas mudanças ambientais (SILVA et al., 2016).

\section{CONCLUSÃO}

0 processo de desmatamento ilegal acontece em todo o mundo em decorrência das atividades produtivas, econômicas e devido ao aumento populacional, e tendo em vista esses fatores, há uma grande necessidade de impor mais rigor nas fiscalizações em relação a esse crime ambiental.

Tendo em vista que o intenso desmatamento nas áreas da Amazônia Maranhense ocasiona a perda da vegetação nativa, o levantamento de áreas desmatadas é essencial para realizar a identificação das regiões degradadas, permitindo assim elaborar um plano de gestão e manejo sustentável em associação com as legislações vigentes a fim de garantir a sua preservação. Sendo assim, o Engenheiro Agrônomo poderá contribuir desenvolvendo medidas que visam reduzir a extinção de espécies, tanto de animais quanto vegetais, instruindo acerca de técnicas de manejo sustentável e conservação para as áreas degradadas, além de desenvolver ações voltadas à mitigação de possíveis impactos ambientais que venham a ocorrer.

Vale destacar ainda a importância das leis ambientais e as políticas públicas que são de extrema importância para garantir a manutenção dos recursos naturais e das nossas florestas. Tendo em vista as grandes problemáticas enfrentadas atualmente, como as degradações dos solos e os desmatamentos causados, principalmente, pela pecuária e extração de madeira, algumas alternativas tem sido adotadas como sugestões para minimizar esses danos, um exemplo disso temos o ILPF que integra lavoura, pecuária e floresta sendo uma atividade altamente sustentável capaz de reduzir a emissão de carbono sequestrando esses gases da atmosfera, o que por sua vez acaba contribuindo para a diminuição do efeito estufa.

Assim, tendo em vista as consequências do desmatamento, fica claro a importância das áreas protegidas como ferramenta para minimizar esse processo e a atuação de forma efetiva do novo código florestal a fim de garantir a exploração de forma racional dos recursos naturais. 


\section{REFERÊNCIAS}

ALVIM, M. Novo Código Florestal: cinco anos depois. 0 Globo, [s. l.], 2017. Disponível em: https://oglobo.globo.com/sociedade/ciencia/meio-ambiente/novocodigo-florestal-cinco-anos-depois-21432468\# ixzz57B3IOUiU. Acesso em: 23 jun.2021.

ANTONIAZZI, G. A. O agronegócio e os conflitos agrários: uma análise dos seus impactos na Amazônia Legal. Revista Âmbito Jurídico, [s. l.], ano 21, n. 169, 8 fev. 2018. ISSN 1518-0360 Disponível em: https://ambitojuridico.com.br/revista-ambito-juridico/revista-ambitojuridico-no-169-ano-xxi-fevereiro-2018/. Acesso em: 24 jun. 2021.

BENTO, A. Como fazer uma revisão da literatura: Considerações teóricas e práticas. Revista JA (Associação Académica da Universidade da Madeira), [s. l.], ano 7, n. 65 p. 42-44, maio 2012. ISSN 1647-8975. Disponível em: http://www3.uma.pt/bento/Repositorio/Revisaodaliteratura.pdf. Acesso em: 10 jun. 2021.

ECO. Dicionário ambiental: o que é a Amazônia Legal. ((0)) eco, Rio de Janeiro, nov.2014. Disponível em: https://www.oeco.org.br/dicionarioambiental/28783-o-que-e-a-amazonia-legal/. Acesso em: 14 jun. 2021.

FONSECA, A. L. et al. Boletim do desmatamento da Amazônia Legal (abril 2021) SAD. Belém: Imazon, p. 1, 2021. Disponível em: https://imazon.org.br/publicacoes/boletim-do-desmatamento-daamazonia-legal-abril-2021-sad/. Acesso em: 20 jun. 2021.

G1 MA. Maranhão perdeu 80\% da floresta Amazônia nos últimos 70 anos. G1-MA. 2019.

Disponível

em: https://g1.globo.com/ma/maranhao/noticia/2019/09/11/maranhaoperdeu-80percent-da-floresta-amazonica-nos-ultimos-70-anos.ghtml. Acesso em: 13 jun. 2021.

IBGE- INSTITUTO BRASILEIRO DE GEOGRAFIA E ESTATÍSTICA. Amazônia Legal. 2020. Disponível em: https://www.ibge.gov.br/geociencias/cartas-emapas/mapas-regionais/15819-amazonia-legal.html?=\&t=o-que-e. Acesso em: 16 jun. 2021.

IMESC. Relatório Técnico de Classificação da Vegetação do Zoneamento Ecológico Econômico do Estado do Maranhão (ZEE-MA): etapa bioma amazônico. São Luís: IMESC, 2020. 196 p. ISBN 978-85-61929-25-1. Disponível em: http://www.zee.ma.gov.br/src/upload/relatorios/Vegetacao.pdf. Acesso em: 14 jun. 2021.

ISPN. Amazônia: ameaça à Amazônia. Instituto Sociedade, População e Natureza. 2019. Disponível em: https://ispn.org.br/biomas/amazonia/ameacas-aamazonia/. Acesso em: 19 jun. 2021. 
MAURANO, L. E. P.; ESCADA, M. I. S.; RENNO, C. D. Padrões espaciais de desmatamento e a estimativa da exatidão dos mapas do PRODES para Amazônia Legal Brasileira. SciELO: Ciência Florestal, Santa Maria, v. 29, n. 4, p. 1763-1775, out./dez. 2019. ISSN 1980-5098. Disponível em: https://www.scielo.br/j/cflo/a/hLKygNRzYwPxh7j5yzbpzkM/?lang=pt\#. Acesso em: 20 jun. 2021.

MIOTTO, K. Reportagens: Amazônia maranhense requer atenção para continuar existindo. ((0)) eco, [s. l.], 24 jan. 2012. Disponível em: https://www.oeco.org.br/reportagens/25649-amazonia-maranhenserequer-atencao-para-continuar-existindo. Acesso em: 14 jun. 2021.

PIACENTINI, P. Floresta Amazônia: desmatamento afeta a rica biodiversidade e causa impactos no planeta. EcoDebate, [s. l.], 2012. Disponível em: https://www.ecodebate.com.br/2012/08/20/floresta-amazonicadesmatamento-afeta-a-rica-biodiversidade-e-causa-impactos-no-planeta. Acesso em: 13, jun. 2021.

REBELO, A. Parecer do relator deputado federal Aldo Rebelo (PCdoB-SP) ao Projeto de Lei no 1876/99 e apensados. Disponível em: https://www.camara.leg.br/proposicoesWeb/prop_mostrarintegra?codteo r=777725. Acesso em: 10 jun. 2021.

SANTOS, D.; SALOMÃO, R.; VERISSIMO, A. Fatos da Amazônia 2021. [S. l.]: AMAZÔNIA 2030, mar. 2021. Disponível em: https://amazonia2030.org.br/fatos-da-amazonia-2021/. Acesso em: 19 jun. 2021.

SILVA, A. P. M; MARQUES, H. R.; SAMBUICHI, R. H. R. Mudanças no código florestal brasileiro: desafios para a implementação da nova lei. Rio de Janeiro: Ipea, 2016. 359 p. https://www.ipea.gov.br/portal/images/stories/PDFs/livros/livros/16081 2_livro_mudancas_codigo_florestal_brasileiro.pdf. Acesso em: 23 jun.2021.

SILVA, C. A. A. C. et al. Análise da dinâmica no uso da terra maranhense na Amazônia Legal. Revista Verde. Pombal, Paraíba, v. 14, n. 3, p. 443-453, jul./set. 2019. Disponível

em: https://dialnet.unirioja.es/servlet/articulo?codigo=7155666. Acesso em: 14 jun. 2021.

SILVA, I. C. V. et al. Cenários do desflorestamento da Amazônia Brasileira: O que dizem os estudos. Revista do CEDS, [s. l.], v. 1, n. 4, jan./jul. 2016. Disponível em:

http://sou.undb.edu.br/public/publicacoes/deflorestamento_da_amaz\%C3 \%83\%C2\%B4nia_brasileira_-_isabel_cristina.pdf. Acesso em: 15 jun. 2021.

SPINELLI-ARAUJO, L. et al. Conservação da biodiversidade do Estado do Maranhão: cenário atual em dados geoespaciais. Jaguariúna: Embrapa Meio Ambiente, 2016. 29 p. (Embrapa Meio Ambiente. Documentos, 108). Disponível em: https://www.embrapa.br/busca-de-publicacoes/- 
/publicacao/1069715/conservacao-da-biodiversidade-do-estado-domaranhao-cenario-atual-em-dados-geoespaciais. Acesso em: 20 jun. 2021. 


\section{CAPÍTULO III}

\section{EVOLUÇÃO DO DESMATAMENTO EM MATOPIBA: ASPECTOS RELEVANTES SOBRE O AGRONEGÓCIO E AS POLÍTICAS GOVERNAMENTAIS NO PERÍODO DE 2016 A 2021}

DOI: 10.51859/amplla.lar559.1121-3

Gilvania Sousa Pereira

Universidade Estadual do Maranhão - UEMA, Centro de Ciências Agrárias - CCA, Campus São Luís/MA, Brasil E-mail: gilvaniasousa1999@hotmail.com

Paloma de Sousa Ribeiro

Universidade Estadual do Maranhão - UEMA, Centro de Ciências Agrárias - CCA, Campus São Luís/MA, Brasil E-mail: ribeiroplm17@gmail.com

Renata do Vale Gomes

Universidade Estadual do Maranhão - UEMA, Centro de Ciências Agrárias - CCA, Campus São Luís/MA, Brasil E-mail: natvalegomes@gmail.com

Shirley dos Santos

Universidade Estadual do Maranhão - UEMA, Centro de Ciências Agrárias - CCA, Campus São Luís/MA, Brasil

Denise Maria Santos

ORCID: https://orcid.org/0000-0001-8886-6439 Instituto Dom José de Educação e Cultura IDJ/UVA, Brasil.

E-mail: deniseufc@yahoo.com.br

Andréa de Vasconcelos Freitas Pinto

ORCID: https://orcid.org/0000-0002-9306-418X

Universidade Federal de Alagoas - UFAL, Campus de Engenharias e Ciências Agrárias - CCA, Brasil E-mail: dea_botelho@hotmail.com

Maria José de Holanda Leite

ORCID: https://orcid.org/0000-0003-4154-3901

Universidade Estadual do Maranhão - UEMA, Centro de Ciências Agrárias - CCA, Campus São Luís/MA, Brasil E-mail:maryholanda@gmail.com

\section{RESUMO}

O Brasil é um dos maiores produtores agrícolas do mundo e uma grande parcela da produção está concentrada na região do MATOPIBA, em virtude das características edafoclimáticas favoráveis. Contudo, o processo de tomada destas áreas aliado a carência de políticas públicas que assegurem a permanência da vegetação nativa, tem provocado, nas últimas décadas, transformações drásticas em sua paisagem natural, especialmente no Cerrado, que é o bioma predominante, resultando em diversos problemas socioambientais. À vista disso, o objetivo deste trabalho é analisar como o agronegócio e as políticas governamentais tem contribuído para a evolução do desmatamento nos estados da região do MATOPIBA entres os anos de 2016 a 2021. Para isto, foi realizada uma revisão bibliográfica para selecionar as principais literaturas e dados para a construção do levantamento das áreas desmatadas. A área de estudo compreende os estados do Maranhão, Tocantins, Piauí e Bahia, abrange 337 municípios em 31 microrregiões geográficas, e somam cerca de 73 milhões de hectares de diversidade natural. 0 levantamento foi realizado conforme a base de dados do INPE (PRODES e DETER). Constatou-se os maiores índices em 2016, 2017, 2018, com 429.892, 455.698, 434.511 hectares de área desmatada, respectivamente, com destaque para os estados do Maranhão e Tocantins. Possivelmente a principal influência foi a ineficiência da Medida 
Provisória 759/Lei no 13.465 e do governo federal da época. Claramente medidas precisam ser tomadas para frear a perda do Cerrado, visto que é um bioma muito representativo e importante para a biodiversidade brasileira e para as comunidades que vivem em torno. Desse modo, é imprescindível que as formas de uso da terra sejam revistas e haja maior investimento tecnológico em meios de produção mais sustentáveis, para que essas áreas deixem de ser descartáveis.

Palavras-chave: economia, cerrado, leis, fronteira agrícola, agropecuária.

\section{INTRODUÇÃo}

O Matopiba é uma região formada pelo estado do Tocantins e partes dos estados do Maranhão, Piauí e Bahia, onde ocorreu forte expansão agrícola a partir da segunda metade dos anos 1980 com foco na produção de grãos (BORGHI et al., 2014). A topografia plana, os solos profundos, o clima favorável, o baixo custo das terras e a mão de obra local barata, ocasionaram o interesse de produtores o que levou a busca por essas novas áreas agricultáveis. Esta expansão ocorreu principalmente nas áreas do cerrado, especialmente em áreas onde são utilizadas pastagens degradadas, sendo possível a agricultura apenas com meios tecnológicos de plantio.

Junto ao destaque econômico e produtivo no cenário brasileiro tem-se a preocupação ambiental com a região do MATOPIBA, que se encontra no bioma Cerrado e apesar da sua dimensão e importância, o Cerrado é um dos ecossistemas mais ameaçados atualmente. 0 processo de tomada da região deste bioma tem provocado, nas últimas décadas, transformações drásticas em sua paisagem natural (AGUIAR, 2016).

O Brasil é um dos maiores exportares de soja do mundo e uma grande parte da produção está concentrada na região Centro Oeste, onde o bioma Cerrado é predominante. Na medida que a fronteira agrícola se expande, novas áreas precisarão estar aptas para a realização das práticas agropecuárias e é neste momento de preparo da área que o desmatamento cresce exponencialmente. Por este motivo este bioma está cada vez mais ameaçado e perde grandes áreas de vegetação nativa (MUELLER; MARTHA JR, 2008). Sendo assim, a um dos principais reflexos da expansão agrícola no Cerrado, onde o MATOPIBA está inserido, é o desmatamento deste bioma (PENA, 2017). 
A destruição de mata nativa do cerrado cresce de forma acelerada, uma vez que o Código Florestal reivindica apenas 35\% de território protegido nas áreas agrícolas com reserva legal no cerrado (BRASIL, 2016), o que facilita bastante o processo de desmate da vegetação nativa. Em virtude deste quadro e por ser regida por leis defasadas e sem proteção do estado, a região do MATOPIBA vem sofrendo um grande desgaste de sua fauna e flora natural, pois atualmente é vista como a região de maior potencial de produção de grãos para o fortalecimento do agronegócio, que é marcado pelas grandes colheitas, especialmente soja, milho e algodão.

Segundo a organização não governamental GREEANPEACE, entre agosto de 2018 e julho de 2019, de acordo com dados do Instituto Nacional de Pesquisas (INPE), foram desmatados $6.484 \mathrm{~km}^{2}$ de Cerrado, uma redução de apenas 2,26\% em relação ao período anterior. A retirada de vegetação nativa se concentrou (62\%) na região do MATOPIBA, tendo como objetivo a produção de soja e bovinos. No dia 24 de agosto de 2020, o decreto criado no ano de 2015 que dispunha sobre o Plano de Desenvolvimento Agropecuário do MATOPIBA - PDA-MATOPIBA (decreto $\mathrm{n}^{\mathrm{o}}$ 8.447), foi revogado pelo governo Bolsonaro, que atualmente se encontra sem planos de preservação ou desenvolvimento sustentável para a região e se encontra desprotegida do avanço excessivo do agronegócio.

Nossa pesquisa, teve como objetivo analisar como o agronegócio e as políticas governamentais tem contribuído para a evolução do desmatamento nos estados da região do MATOPIBA entres os anos de 2016 a 2021, para responder a esse objetivo; a) buscou-se quantificar o desmate de áreas com vegetação nativa entre os anos de 2016 e 2021; b) as causas mais relevantes do desmatamento neste período; c) averiguar as políticas governamentais que abrangem a preservação da área estudada e; d) analisar a eficiência das políticas na contenção do desmatamento nessa região.

\section{METODOLOGIA}

O bioma Cerrado é predominante no MATOPIBA e ocupa 66,5 milhões de hectares, o equivalente a 91\% da área. Remanescentes do bioma Amazônia (5,3 milhões ha ou 7,3\% da área) e Caatinga (1,2 milhões de hectares ou 1,7\% da área) são encontrados nos limites noroeste e leste da região, respectivamente. Três bacias 
hidrográficas estão presentes: Bacia do Rio Tocantins (ocupando 43\% da área do MATOPIBA), Bacia do Atlântico - Trecho Norte/Nordeste (com 40\%) e Bacia do Rio São Francisco (com 17\%) (EMBRAPA). A região compreende 337 municípios em 31 microrregiões geográficas, que somam cerca de 73 milhões de hectares (Figura 1).
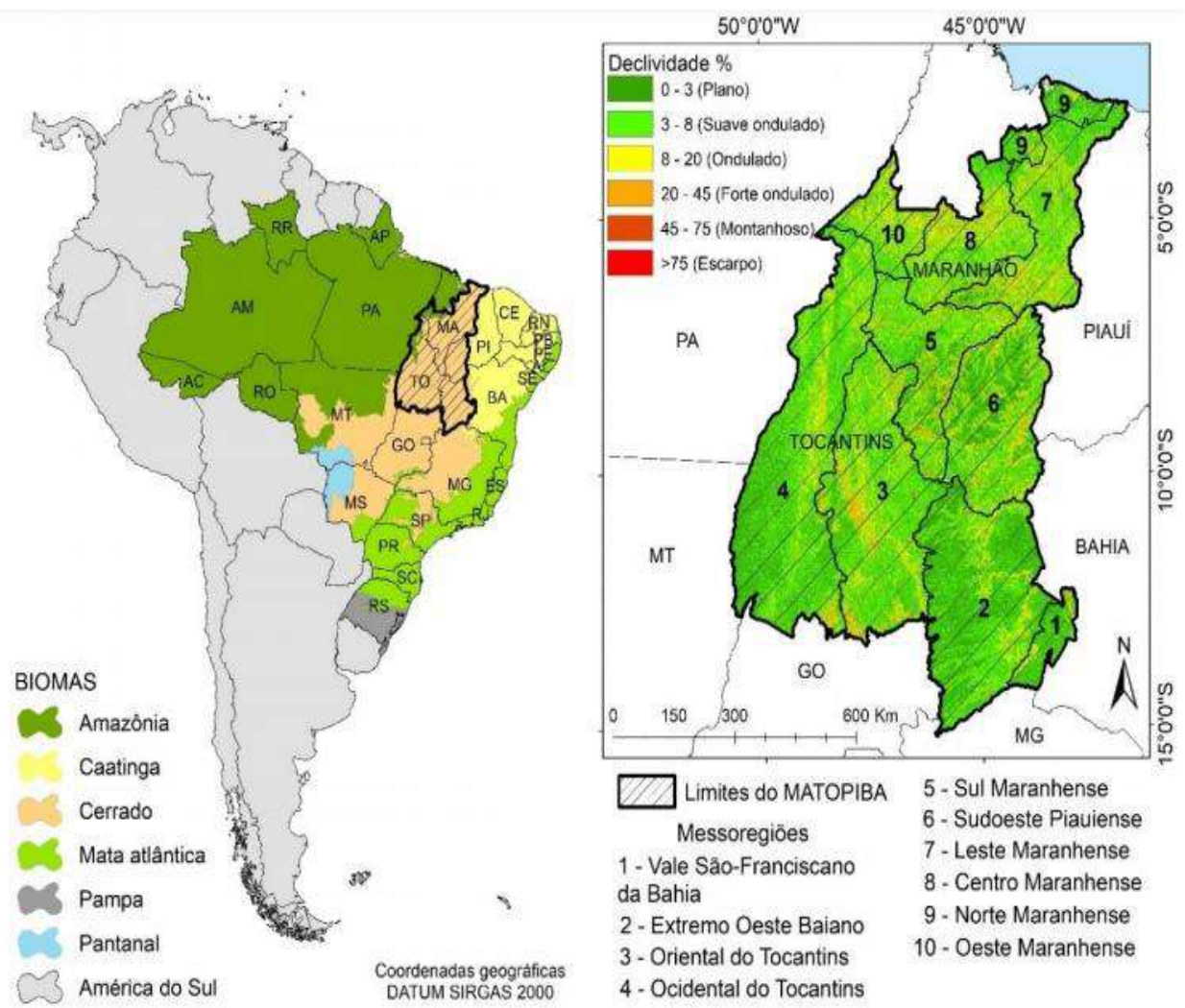

Figura 1. Área de estudo: fronteira agrícola do MATOPIBA e suas mesorregiões, compreendida por porções dos estados do Maranhão, Tocantins, Piauí e Bahia, incluindo 151 municípios.

Fonte: LIMA, 2020.

Além da delimitação territorial, o MATOPIBA é composto por cenários de grande diversidade e complexidade, abrangendo desde questões sociais como a convivência, no mesmo território, de agricultura empresarial e familiar, áreas de preservação, indígenas e quilombolas até nas questões relacionadas à caracterização de solo e clima que definem a região. De tal modo, é importante ressaltar algumas características predominantes que tornaram a região de interesse para o setor agrícola, como bioma, relevo e solos (Tabela 1). 
Tabela 1. Área $\left(\mathrm{km}^{2}\right.$ e \%) das características predominantes nos munícipios do MATOPIBA com grande participação na produção nacional de soja, milho e algodão em 2012.

\begin{tabular}{|c|c|c|}
\hline \multicolumn{3}{|c|}{ Biomas } \\
\hline Nome do bioma & Área $\left(\mathrm{km}^{2}\right)$ & Porcentagem (\%) \\
\hline Cerrado & $234.400,65$ & 93,89 \\
\hline Transição & $7.765,51$ & 3,11 \\
\hline \multicolumn{3}{|l|}{ Cerrado-Caatinga } \\
\hline Transição Amazônia- & $6.838,77$ & 2,74 \\
\hline \multicolumn{3}{|l|}{ Cerrado } \\
\hline Outros & 659,84 & 0,26 \\
\hline \multicolumn{3}{|c|}{ Climas } \\
\hline Período sem chuva & Área $\left(\mathrm{km}^{2}\right)$ & Porcentagem (\%) \\
\hline 4 a 5 meses & $222.002,00$ & 88,92 \\
\hline 6 meses & $27.662,77$ & 11,08 \\
\hline \multicolumn{3}{|c|}{ Relevos } \\
\hline Unidade & Área & Porcentagem (\%) \\
\hline \multicolumn{3}{|l|}{ geomorfológica } \\
\hline Chapadas & $123.107,99$ & 49,31 \\
\hline Depressões & $84.017,18$ & 33,65 \\
\hline Patamares & $18.885,13$ & 7,56 \\
\hline Outros & $23.654,47$ & 9,47 \\
\hline \multicolumn{3}{|c|}{ Solos } \\
\hline Ordem & Área $\left(\mathrm{km}^{2}\right)$ & Porcentagem (\%) \\
\hline Latossolo & $126.966,84$ & 50,85 \\
\hline Neossolo & $85.729,52$ & 34,34 \\
\hline Plintossolo & $22.461,20$ & 9,00 \\
\hline Outros & $14.507,21$ & 5,81 \\
\hline
\end{tabular}

Fonte: EMPRAPA (sem data).

Para formar o presente trabalho, foram utilizadas várias pesquisas bibliográficas consideradas fundamentais e de muita importância para a região do MATOPIBA, com o intuito de investigar resumidamente os acontecimentos que poderão dar uma visão total sobre o assunto.

Vale ressaltar que, a revisão de literatura é imprescindível para a elaboração de um trabalho científico, pois é importante para a qualidade do projeto e da pesquisa. Na elaboração de trabalhos científico é preciso ter uma ideia clara do problema a ser resolvido e para que isso ocorra com clareza a revisão é fundamental. 
A partir da revisão de literatura pode-se ter ideia do que já foi e do que ainda necessita ser pesquisado o problema pode surgir a partir de outros trabalhos como nas recomendações apontadas em artigos, livros, periódicos e outros o que não deixa de ser uma revisão.

A seguir serão expostos alguns pontos que são indispensáveis sobre a região, como levantamento histórico, registros, levantamento de atividades desenvolvidas e economia. Ao longo da apresentação dos tópicos, será possível compreender a temática abordada.

\section{RESULTADOS E DISCUSSÃO}

\subsection{MATOPIBA: a última fronteira agrícola do Brasil}

Mesmo que a redução do desmatamento esteja prevista nas ações apresentadas pelo governo brasileiro na Conferência das Partes, o país ainda possui considerável fronteira agrícola a ser utilizada. Tal fronteira está localizada na região conhecida como MATOPIBA (EMBRAPA, 2017). Trata-se de uma região com grande potencial para expansão agrícola e para a criação e funcionamento de novos mercados (Instituto de Economia Agrícola - IEA, 2015), por possuir características climáticas favoráveis e "terra em abundância" para a produção agropecuária. Por ter esses atributos, a região está sendo considerada a última fronteira agrícola do mundo, e os efeitos disso estão sendo observados nos últimos anos através do destaque na produção de grãos, carne e cana-de-açúcar (EMBRAPA, 2018).

As investigações recentes sobre as mudanças do uso da terra no território brasileiro têm-se concentrado na Amazônia e no Centro-Oeste. Porém, a região em que a área plantada com grãos mais cresce no Brasil é o cerrado nordestino (IBGE, 2016). Com potencial agrícola promissor, esta região apresentou uma escala crescente em área plantada e na produção de grãos e outros produtos oriundos da agricultura (MIRANDA et al., 2014).

Segundo os dados do estudo "Projeções do Agronegócio, Brasil 2015/2016 a 2025/2026", a região deverá produzir 24,4 milhões de toneladas de grãos em 2025/26, caracterizando um aumento de 17,35\% em relação às safras de 2015/16 e o preço da terra é 
o grande motivador da expansão agrícola na região (MAPA, 2016). Os quatro Estados que compõem o MATOPIBA devem aumentar a produção de grãos entre 29 e 36,7 milhões de toneladas em período de dez anos, de acordo com a estimativa oficial em seus limites mínimo e máximo. Isso equivalerá a cerca de 30\% e 38\% da soja a ser exportada.

\subsection{Histórico do desmatamento na região do MATOPIBA}

Na região do MATOPIBA a maior parte do desmatamento está relacionada às atividades de expansão da produção de commodities agrícola. É o local de maior preocupação em relação ao desmatamento no Cerrado, visto que os quatro estados dessa que mais desmataram desde 2009 são justamente os estados que compõem essa região. Dessa forma, o MATOPIBA tem participação crescente no ritmo do desmatamento do bioma Cerrado (SANTOS, 2018).

Os satélites do Instituto Nacional de Pesquisas Espaciais (Inpe) monitoram o desmatamento do bioma Cerrado desde 2000 por meio do sistema PRODES, cujos dados tornaram-se anuais (de agosto de um ano a julho do ano seguinte) a partir de 2013. Nesse período, de quase duas décadas, o ritmo do desmatamento do Cerrado diminuiu, mas se manteve mais elevado do que o da Amazônia até 2016. Em 2003, o município de Formosa do Rio Preto (BA), onde oficialmente houve a expansão da fronteira agrícola no MATOPIBA, alcançou o topo do ranking dos municípios que mais perderam vegetação nativa no Cerrado. A partir de 2005, municípios do Matopiba passaram a liderar o ranking dos maiores desmatadores. No período entre 2000 e 2008, a média dessa participação foi de pouco menos de 40\%. Em 2013, a supressão de vegetação nativa no Matopiba ultrapassou $60 \%$ do desmatamento ocorrido em todo o bioma cerrado. Entre 2013 a 2018, consideraram-se cinco municípios recordistas em desmatamento no cerrado: São Desidério (BA), Baixada Grande do Ribeiro (PI), Urucuí (PI), Balsas (MA) e Formosa do Rio Preto (BA) (SALOMON, 2020).

De acordo com o INPE, em todos os anos entre 2000 e 2016, com exceção de 2005 e de 2009, por uma diferença muito pequena, o desmatamento do bioma Cerrado superou a perda de vegetação nativa do bioma Amazônia. Mesmo em 2004, quando a Amazônia perdeu 27,8 mil km² de floresta (recorde do período de quase duas décadas, só superado pela taxa apurada em 1995), o desmatamento no Cerrado 


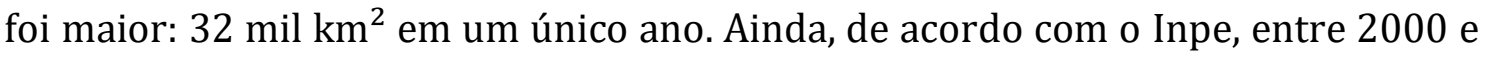
2019, o Matopiba perdeu 126.036 km² de vegetação nativa.

\subsection{Evolução do desmatamento nos estados pertencentes ao} MATOPIBA no período de 2016 a 2021

O Instituto Nacional de Pesquisas Espaciais (INPE), através dos projetos PRODES e DETER, monitora e quantifica anualmente a retirada de vegetação natural dos biomas Cerrado e Amazônia com a utilização de satélites Landsat ou similares. Por meio destas bases de dados foi possível criar uma série história de 2016 até o mês de maio de 2021 com focos e avisos de desmatamento nos estados pertencentes ao MATOPIBA (Gráfico 1).

Os anos de 2016, 2017 e 2018 ultrapassaram a marca de 400.000 hectares de área desmatada, uma alta significativa quando comparado aos índices dos anos subsequentes. Em 2016 o Governo Federal publicou a Medida Provisória 759, com o intuito de modernizar a regularização fundiária do país, contudo, foi interpretada como uma ofensiva conservadora-liberal do então presidente Michel Temer, visto que a MP 759 deixou várias lacunas, entre elas a extinção do conceito de regularização fundiária rural e urbana (RIBEIRO et al., 2017). Mais tarde, em 2017, foi promulgada a Lei no 13.465 com o objetivo de consolidar a Medida Provisória 759, o que acabou favorecendo o avanço do agronegócio em áreas com vegetação nativa e consequentemente o desmate desta área. Vale ressaltar que o ano de 2017 foi marcado por muitos conflitos agrários e é considerado um dos mais violentos desde 2003. Coincidentemente ou não, os anos que registraram os maiores índices de desmatamento no período estudado, conforme mostra a Figura 2, coincidem com os anos de mandato do presidente empossado, Michel Temer (2016 a 2018). 


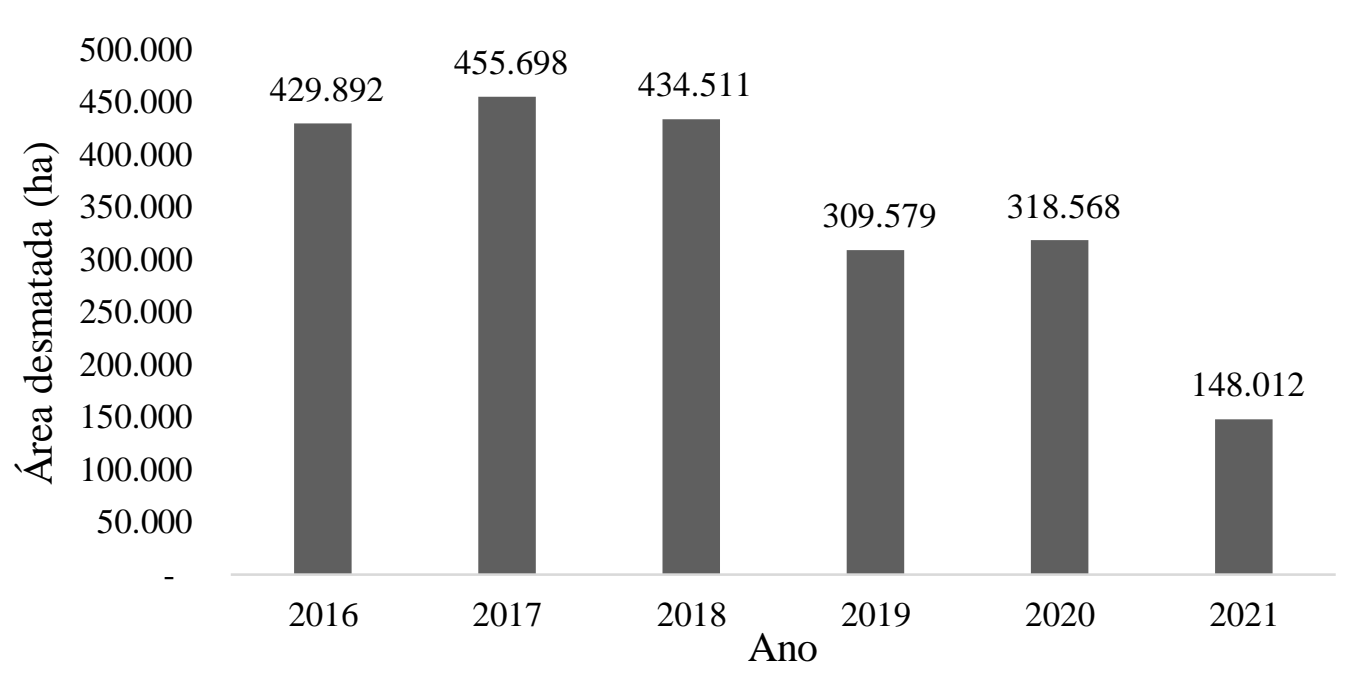

Figura 2. Índices anuais de retirada de cobertura vegetal natural nos estados pertencentes ao MATOPIBA (2016/2021).

Fonte: Elaborado pelos próprios autores, 2021.

A extensão territorial e aptidão agrícola da terra são os fatores que estão diretamente ligados a expansão do agronegócio nos estados da Bahia, Maranhão, Piauí e Tocantins. Analisando por estado/ano, nos períodos de 2016 e 2017, o TO e o MA apresentaram os maiores índices de desmatamento em comparação aos demais estados do MATOPIBA (Figura 3). Neste mesmo período houve uma evolução acentuada no uso proporcional de terras pela cultura da soja no estado do Tocantins (FERREIRA; MARQUES, 2020), enquanto o Maranhão caia em produção, pois ainda se recuperava da seca que afetou o Nordeste em 2015 ocasionada pelo El Niño. Segundo dados do Inpe, o Maranhão foi o $3^{\circ}$ estado em número de queimadas 2016, índice que foi alavancado pelo cenário de seca do ano interior. No ano de 2017 o estado continuou registrando focos de incêndio e chegou a ter um aumento de $76 \%$ em relação ao ano anterior. Sendo assim, as queimadas podem ser apontadas como principal causa de perda de cobertura vegetal neste período no estado, uma vez que a produtividade caiu neste intervalo de tempo. 


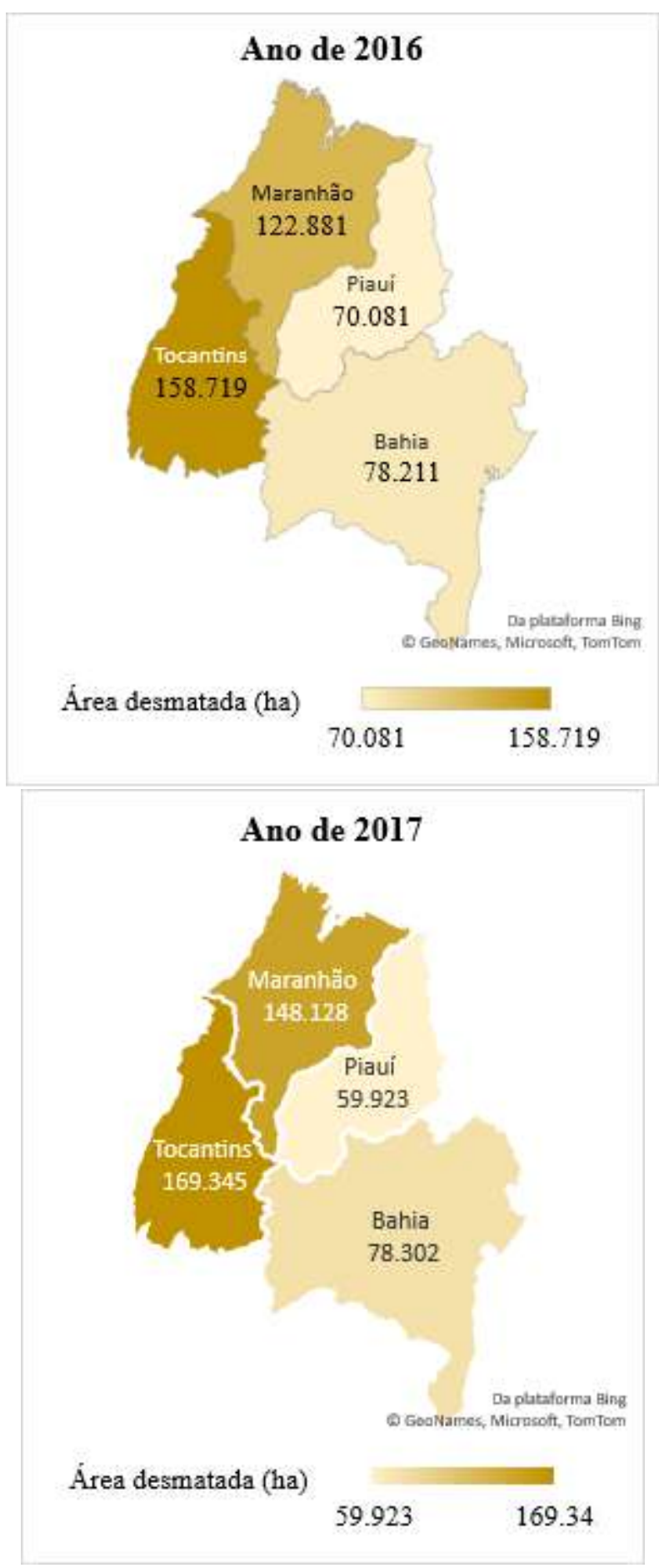

Figura 3. Levantamento perda de cobertura vegetal por estado nos anos de 2016 e 2017.

Fonte: Elaborado pelos próprios autores, 2021.

No ano de 2018 houve uma leve queda nos índices de desmatamento nos estados do MA, BA e PI, porém, o TO foi na contramão dessa redução (Mapa 2). De acordo com a Federação da Agricultura e Pecuária do Estado do Tocantins - FAET (2018), o estado foi o $11^{\text {o }}$ que mais expandiu no setor do agronegócio brasileiro no 
ano de 2017 e a estimativa para o ano de 2018 era acima do ano anterior. A relação entre evolução da agropecuária e desmatamento infelizmente é diretamente proporcional e os dados confirmam que na medida que o estado expande o agronegócio, mais áreas são desmatadas.

Em 2019 todos os estados reduziram a taxa de desmatamento (Figura 4), contudo, para o Greenpeace (2019), mesmo com a redução em relação ano de 2018, a área perdida representa quatro vezes o tamanho da cidade de São Paulo e organização aponta as atividades agropecuárias (soja e gado) como principais causas para perda de cobertura vegetal na região. 


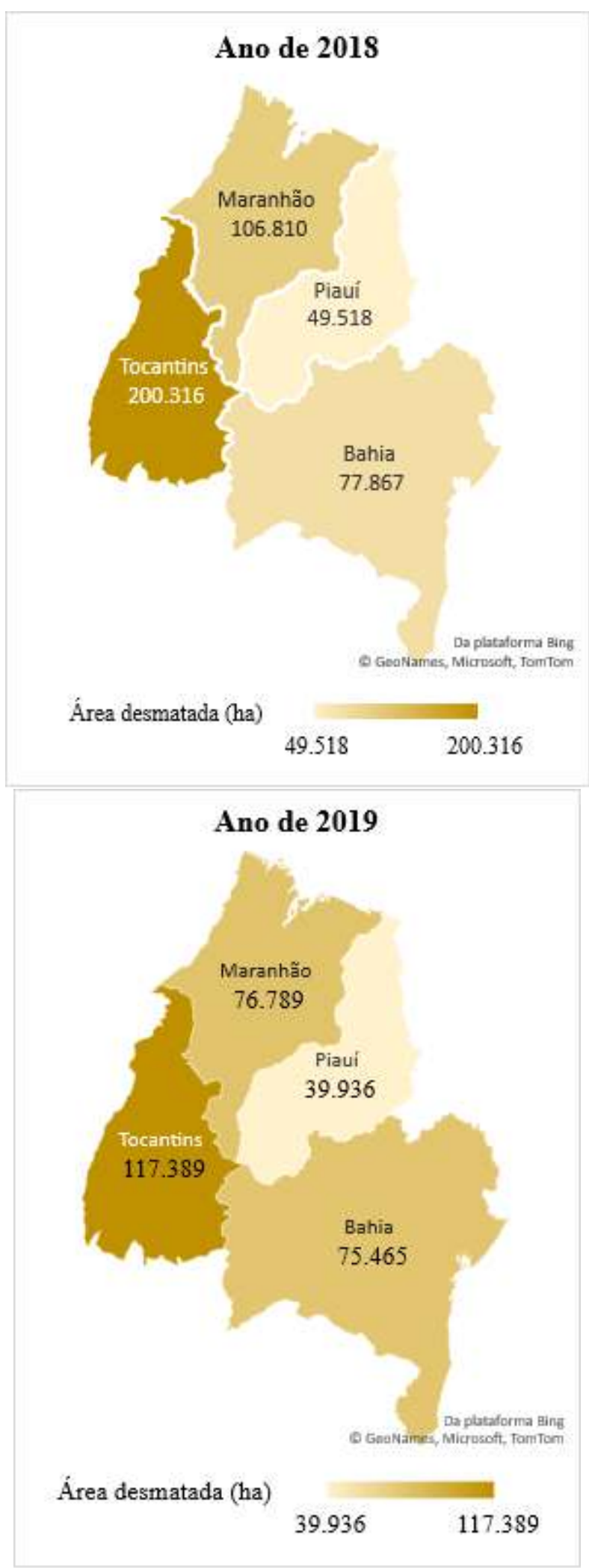

Figura 4. Levantamento perda de cobertura vegetal por estado nos anos de 2018 e 2019.

Fonte: Elaborado pelos próprios autores, 2021. 
Em 2020 o Maranhão foi o único estado que expressou aumento significativo das áreas desmatadas (Mapa 3). De acordo com dados do Levantamento Sistemático da Produção Agrícola (LSPA), a safra maranhense bateu recorde neste período, com um crescimento de 9,2\% quando comparado à safra de 2019 , com destaque para a produção de soja, arroz e milho (SEPE, 2020).

O Tocantins, embora tenha um índice alto de desmatamento neste período, reduziu consideravelmente esta taxa em relação ao período passado. Segundo a Secretaria de Estado da Agricultura, Pecuária e Aquicultura (Seagro), o estado continuou registrando crescimento no setor do agronegócio, principalmente na pecuária de corte. Contudo, o Governo do Tocantins buscou e apresentou aos produtores recursos para desburocratização e modernização da estrutura institucional e da legislação ambiental no ano de 2020, o que de certa forma proporcionou a redução do desmatamento, uma vez que estas medidas atraíram mais investidores e o próprio estado investiu mais em genética (OLIVEIRA; THEOPHILO, 2021). A produção não cresceu somente em virtude da área de pasto, e sim em função do melhoramento genético do rebanho. Este é um exemplo que há alternativas viáveis para reduzir o desmatamento sem diminuir a produtividade, basta haver investimento em tecnologia e assegurar juridicamente os produtores.

Analisando o período de 2012 a 2020 e no período inicial de 2021 (Figura 5) é possível observar que a Bahia não tem grandes picos nas taxas de perda de cobertura vegetal, mesmo tendo a soja com uma das culturas produzidas no estado. Vale ressaltar que o estado vem registrando recordes históricos ao longo do período estudado e ainda sim conseguiu manter os índices de desmatamento sem grandes oscilações. Segundo a Associação de Agricultores Irrigantes da Bahia - AIBA, os resultados satisfatórios de devem ao aumento da produtividade por hectares com o implemento de melhoramento genético, o alto investimento em tecnologia, manejo e fertilização do solo, além de contar com um clima bastante favorável e chuvas bem distribuídas (AIBA, 2018).

O Piauí, embora tenha extensão territorial inferior aos demais estados da área de estudo, desde 2016 vem reduzindo o índice de perda de cobertura vegetal, ao passo que nos anos de 2020 e início de 2021, foi o estado que menos desmatou (Figura 5). Porém, ele também segue crescendo em produtividade, só em 2021 a estimativa é que a produção de grãos cresça cerca de 9,74\% em relação ao ano 
passado, e alcançará o segundo maior crescimento do Brasil, com destaque para a produção de soja. Um ponto muito importante que possivelmente vem ajudando nesse cenário é o Governo do Estado através do Instituto de Terras do Piauí (INTERPI) que está contribuindo ativamente desde 2019 para a regularização fundiária no estado. A Lei Estadual no 7.294/2019 trouxe paz ao campo e ofereceu maior segurança para os produtores ao investir nas suas propriedades rurais. Para Wellington Dias, então governador do Piauí, “A regularização fundiária e avanço na infraestrutura no sul do Piauí, tem impulsionado o crescimento econômico, com mais produção de grãos, algodão e madeira certificada - que reduz pressão sobre a derrubada da floresta". Mais um exemplo que reduzir as taxas de desmatamento pode e deve ser um trabalho de organização jurídica e além disso, um serviço de fortalecimento dos produtores rurais (PEDROSA, 2021). 


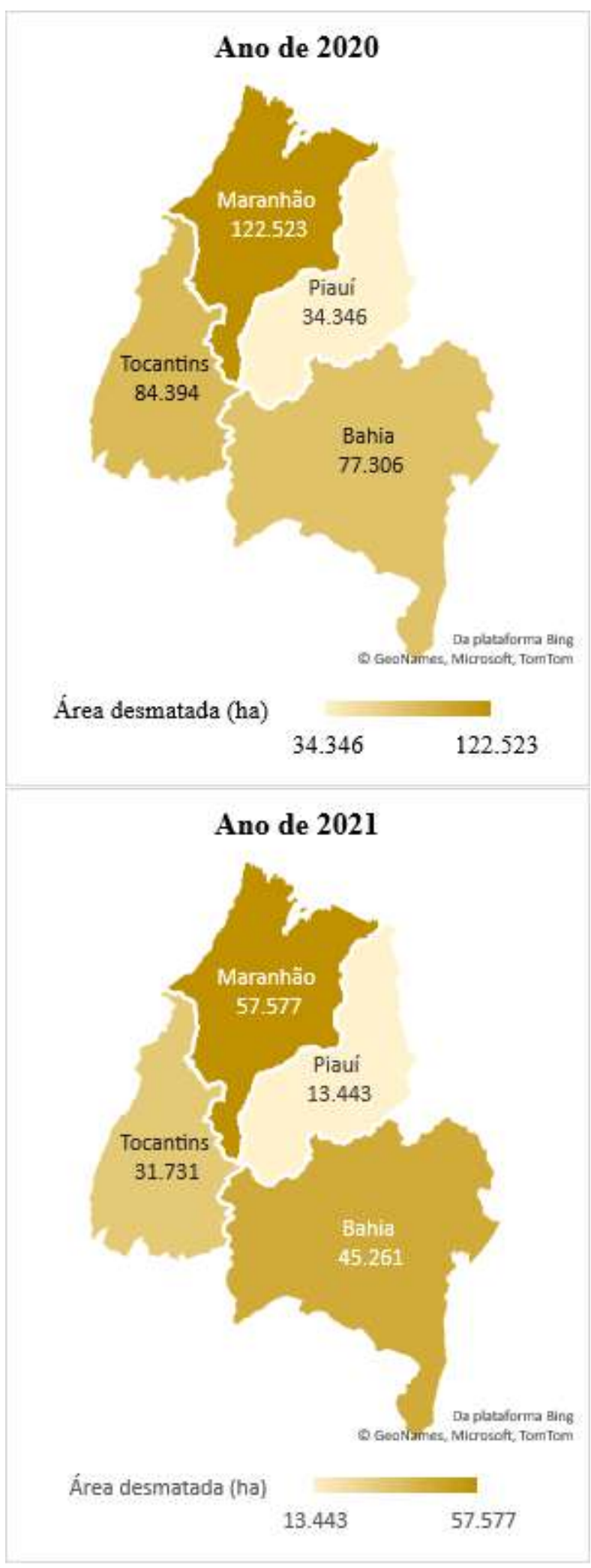

Figura 5. Levantamento perda de cobertura vegetal por estado nos anos de 2020 até maio de 2021.

Fonte: Elaborado pelos próprios autores, 2021. 
A região do MATOPIBA, por se tratar da última fronteira agrícola do Brasil, teve índices elevados de desmatamento no período estudado. Na figura 6, é possível observar que os alertas de desmatamento se encontram bem distribuídos ao longo da área, porém apresenta maiores concentrações na mesorregião central do Maranhão e na microrregião Rio Formoso do Tocantins. Curiosamente, segundo Costa (2016) no território de Rio Formoso está localizada a maior ilha fluvial do mundo (Ilha do Bananal) e tem água em abundância, recurso natural bastante cobiçado por agricultores. A ocorrência dos alertas (apenas as correspondentes à delimitação do MATOPIBA), apontam que os índices de desmatamento constatados para cada estado em sua totalidade estão em grande parte dentro da fronteira agrícola, desse modo, fica mais nítido a influência que o agronegócio exerce sobre o avanço da perda de cobertura vegetal.

Em alguns pontos observa-se que áreas com um histórico representativo na produção agrícola, como é o caso do sul do Maranhão, não concentram muitos alertas de desmatamento. Isso pode se dar ao fato dessas áreas já estarem sendo utilizadas há muito tempo e foram desmatadas em anos anteriores ao nosso período de estudo. 


\section{ALERTA DE DESMATAMENTO (DETER) NA REGIÃO DO MATOPIBA ENTRE OS ANOS DE 2016 A 2021}

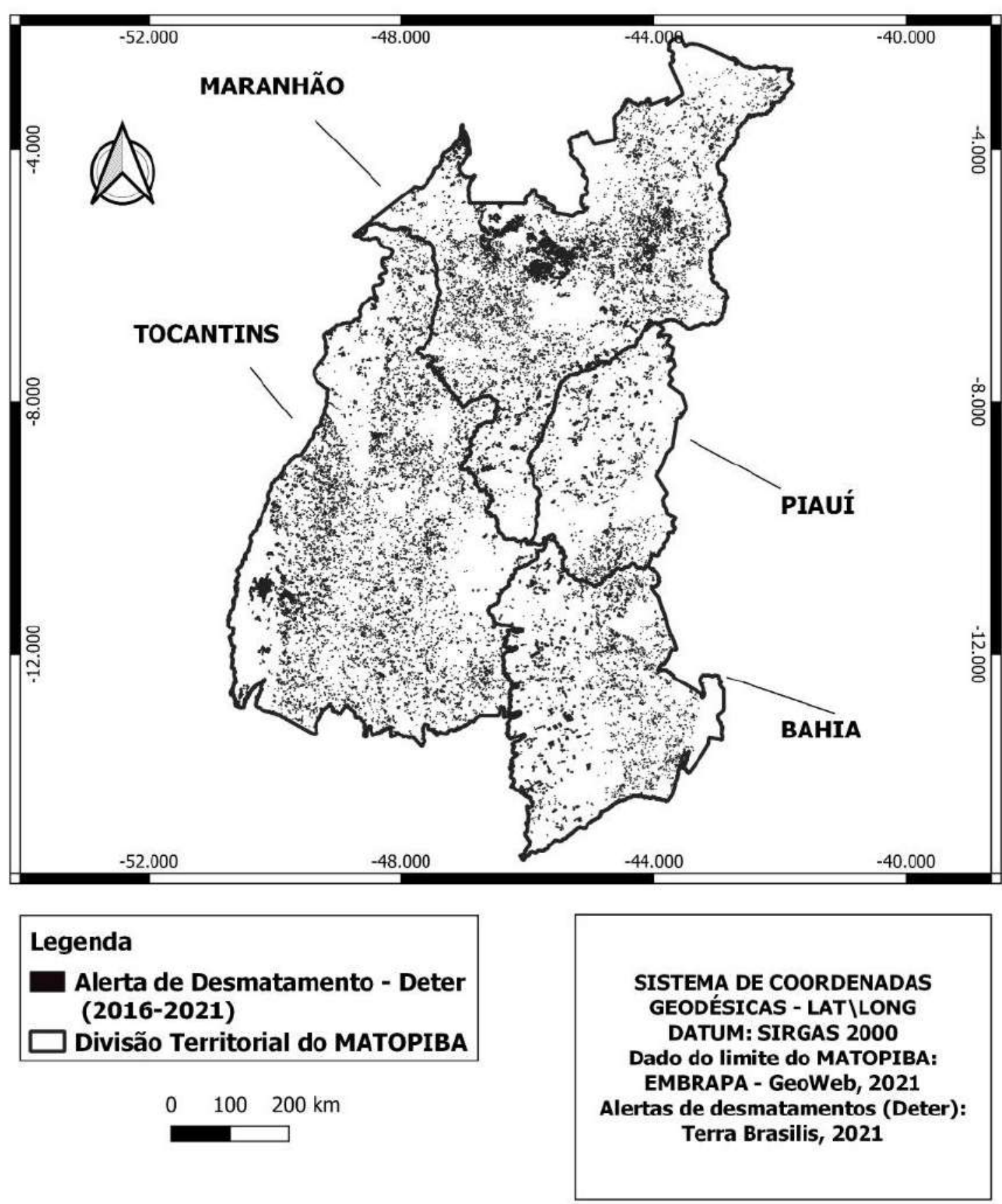

Figura 6. Alertas de desmatamento na região do MATOPIBA entre os anos de 2016 a 2021.

Fonte: Elaborado pelos próprios autores, 2021. 
4. PRINCIPAIS ATIVIDADES ECONÔMICAS DESENVOLVIDAS NA REGIÃO

No território do MATOPIBA, a agropecuária é protagonista do processo de desenvolvimento regional (CASTRO, 2012). O território engloba 324.326 estabelecimentos agrícolas, o que equivale uma área de 33.929.100 hectare.

Nas últimas duas décadas, a área do MATOPIBA sofreu grandes transformações, com destaque na produção de grão no mercado internacional. A principal cultura nas principais áreas de cultivo do Matopiba atualmente é a soja. No entanto, outras culturas como arroz e algodão também desempenham papéis importantes. De acordo com o levantamento, grande parte desse aumento na produtividade de grãos se deve ao acesso às tecnologias hoje empregadas como o uso de híbridos e cultivares adaptados às condições edafoclimáticas (EMBRAPA, 2021). A microrregião de Barreiras é a maior produtora de algodão, feijão, milho, soja e sorgo do Matopiba, liderada principalmente pelo município de São Desidério, o qual é o líder na produção de algodão e milho, seguido de Formosa do Rio Preto, o principal produtor de soja (PEREIRA, 2018).

Algumas características favoráveis do Cerrado, bioma que abrange quase que totalmente a região do Matopiba, associadas ao preço das terras e ao uso de modernas práticas agrícolas, fazem da região um atrativo para agricultores vindos de outros estados, e que buscam áreas extensas e baratas para o desenvolvimento de agricultura empresarial em larga escala (PORCIONATO et al. 2018).

Entre 2000 e 2013 o setor terciário foi o que mais se destacou, seguido da agropecuária e indústria. Em 2000 o setor de serviços se destacou no Estado do Tocantins com 65,8\%, seguido do Maranhão 64,3\%, Piauí com 61,6 \% e Bahia com 49\%. Já no ano de 2006 o Estado do Piauí foi o que mais se destacou com 69,8\%, seguido do Maranhão com 59,9\%, depois Tocantins com 57,4\% e Bahia 53,7\%. No ano de 2013 o Estado do Tocantins recuperou a hegemonia no setor serviço chegou a arrecadar 70,8\% neste setor, seguido de Maranhão 66,1\%; Piauí -57,9\%; Bahia 55,8\%. Em 2017 o setor agropecuário correspondeu a 23\%, a indústria 47\% e serviços 75\% sendo serviços 50\% e Administração pública 25\% (OLIVEIRA, 2020). 


\subsection{Evolução e impactos do Agronegócio}

A região do MATOPIBA vem passando por grandes mudanças nos aspectos econômicos e sociais, em função principalmente da expansão do agronegócio. Em virtude das boas condições edafoclimáticas locais para a produção de grãos, o Matopiba se tornou um grande produtor de grãos nos últimos anos e tem expressado grande potencial agrícola (PEREIRA et al., 2018). Somente entre os anos de 2000 e 2014, na região a área plantada com soja e cana-de-açúcar aumentou $253 \%$ e 379\%, respectivamente (CERDAS, 2015).

Contudo, essa capacidade produtiva trouxe diversas problemáticas para os moradores da região. Uma das consequências da expansão do agronegócio no Matopiba é a subida dos preços das terras, como consequência do aumento dos preços das commodities no mercado internacional. Este processo também promoveu o aumento da prática de grilagem de terras, tanto por transnacionais proprietárias fundiárias, quanto por terceiros, que se apropriam ilegalmente dessas áreas e as comercializam (PITTA et al., 2017).

Com a expansão da agricultura, sobretudo a produção de soja, as comunidades rurais do Matopiba começaram a ser cercadas e pressionadas pelas agroindústrias. Para APROSOJA (2019), não é o cerrado do Matopiba que está ameaçado, são pessoas desta região, pois sofrerão com a pobreza, desnutrição, falta de emprego, oportunidades e qualidade de vida. A grande questão é que em virtude da expropriação, as terras que anteriormente eram utilizadas secularmente por camponeses e pequenos produtores rurais passaram a ser ocupadas por grandes plantações de soja, sendo assim, essa população muda totalmente seu modo de vida (PITTA et al., 2017). Além das comunidades rurais, a grilagem e a expropriação da terra atingem indígenas e quilombolas da região.

Outra consequência da expansão do agronegócio no Matopiba são os impactos ambientais. 0 desmatamento generalizado das áreas do Cerrado das chapadas, mudou o regime pluviométrico da região e prolongou os períodos de seca. Com o passar do tempo e o crescimento do desmate da vegetação nativa, muitos rios secaram, visto que suas nascentes foram totalmente destruídas, além de uma enorme queda no abastecimento de água no lençol freático. A utilização de agrotóxicos nas produções trouxe problemas socioambientais gravíssimos aos moradores do Matopiba, uma vez que a aplicação dos defensivos agrícolas é feita 
por aviões e contamina rios, o lençol freático, impacta na fauna como todo, causa prejuízos nas roças das populações rurais e por fim, contamina os alimentos e consequentemente afeta a saúde dessas pessoas (PITTA et al., 2017).

\subsection{Medidas de enfrentamento ao desmatamento do MATOPIBA}

O MATOPIBA expõe a dificuldade de reproduzir no Cerrado experiência semelhante à Moratória da Soja na Amazônia, acordo liderado pelas grandes tradings, sob pressão de entidades ambientalistas, e que ajudou a reduzir o ritmo de desmatamento na floresta entre 2006 e 2018. A conjuntura política brasileira no momento da pesquisa colabora para debilitar esforços de governança ambiental ou alinhada à sustentabilidade, no sentido mais amplo.

Afim de evitar maiores danos ambientais, a Agrosatélite (2015) e o Observatório do Clima (2017) estimaram que no MATOPIBA existem cerca de 8,2 milhões de hectares de área degradada que poderiam ser revitalizadas e reinseridas no processo produtivo. Isso garantiria a continuidade do crescimento agrícola, sem pressão por novos desmatamentos e, consequentemente, preservação de habitats naturais únicos. Nesse sentido, as ações do Plano ABC se apresentam indiretamente como a principal política pública de apoio à preservação ambiental na região.

Assim, caso as ações do Plano $\mathrm{ABC}$ sejam intensificadas no território do MATOPIBA, haveria, além da mitigação das emissões de GEE e da preservação ambiental, outros benefícios para o meio ambiente e o produtor rural. Como, a proposta de recuperação e manutenção da produtividade das pastagens para a mitigação das emissões de gases do efeito estufa resulta também na produção de biomassa, que permite o aumento da capacidade de suporte dessas pastagens para um ou mais animais por hectare, elevando a produtividade. Consequentemente, cria-se espaço para a entrada de mais animais no pasto, evitando a necessidade de abertura de novas áreas, o que constitui o chamado, "efeito poupa-terra" (OBSERVATÓRIO ABC, 2015).

\subsection{Decretos, leis e normas vigentes para o MATOPIBA}

0 Decreto $\mathrm{n}^{\mathrm{o}}$ 8.447, de 6 de maio de 2015 dispunha sobre o Plano de Desenvolvimento Agropecuário do MATOPIBA - PDA- MATOPIBA, que teve por 
finalidade promover e coordenar políticas públicas voltadas ao desenvolvimento econômico sustentável fundado nas atividades agrícolas e pecuárias que resultem na melhoria da qualidade de vida da população. 0 decreto estabeleceu a criação da Frente Parlamentar em Defesa do Desenvolvimento da Região do MATOPIBA, no entanto esse decreto foi revogado pelo decreto $\mathrm{n}$ - 10.473 , de 24 de agosto de 2020 , criado e colocado em vigência pelo atual governo federal, que anula a validade do decreto criado em 2015 (PRESIDENCIA DA REPÚBLICA).

A segunda ação mais direta foi o projeto de Lei Complementar 279/16 que autorizaria o poder executivo a instituir a Agência de Desenvolvimento do MATOPIBA. De acordo com a proposta compete à agência planejar, articular e desenvolver programas, projetos e ações destinados ao fortalecimento da infraestrutura agrícola da região do MATOPIBA, à inovação tecnológica no campo da agricultura sustentável e à orientação e ao apoio ao produtor rural.

A Lei Nacional de Proteção da Vegetação Nativa (Lei n 12.651, de 25 de maio de 2012), ou simplesmente Novo Código Ambiental, como é conhecida, atualmente não protege mais as áreas de topo de colina, os chamados chapadões do bioma Cerrado, destas então grandes áreas do MATOPIBA encontram-se totalmente desprotegidas da expansão agrícola e do desmatamento (NOOJIPADY, et al., 2017).

Assim, nota-se que a região do MATOPIBA está exposta e desamparada do poder público, sem leis, decretos ou normas vigentes que teriam o papel de controlar o desmatamento desenfreado que a região sofre, ocasionando pobreza social, desigualdade e perda de biodiversidade.

Partindo do ponto de vista agronômico, a região do MATOPIBA possui grande capacidade de produção agrícola e pecuária, por ser de clima, solo, e condições topográficas favoráveis. No entanto o profissional da área não deve apenas olhar para o meio produtivo, mas também se atentar para os impactos socioambientais que envolvem o processo de produção, pois o desmatamento sem controle gera pobreza, perca de biodiversidade, reduz a quantidade de chuvas e desse modo impacta direta e indiretamente na vida da população local.

Mesmo que a região do MATOPIBA seja apta a produção, a visão agronômica deve ser voltada para aumentar o aproveitamento das terras que já foram desmatadas. 0 uso descartável da terra acelera bastante o processo de desmate da vegetação nativa, pois há sempre a perspectiva de desbravar novos espaços para 
sanar a degradação de áreas mais antigas. Sendo assim, é essencial que haja o melhoramento das técnicas de produção para que aumente o potencial produtivo das áreas já utilizadas, além de priorizar a recuperação de áreas desgastadas pela utilização inadequada, ao invés de desmatar novas áreas.

De tal modo é necessário o auxílio técnico de qualidade, acesso à tecnologia e principalmente consciência ambiental e social daqueles que produzem em larga escala. Contudo, o cenário atual deixa claro que consciência ambiental e social é uma utopia, uma vez que essa idealização não faz sentido algum frente ao cifrão capitalista. Ou seja, logicamente um grande produtor não vai abrir mão de uma área para que esta fique protegida, pois isto implica em redução de área plantada e consequentemente diminuição dos ganhos financeiros.

A atitude mais acertada é que haja fiscalização e punição mais severa aos que descumprem as políticas ambientais. Porém, é impossível supervisionar o cumprimento de normativas que sequer existem. A presença de leis, normas ou decretos não é suficiente para conter o desmatamento em outros biomas, como a Amazônia por exemplo, no caso do Cerrado, que se encontra quase totalmente desprotegido, a situação é ainda mais difícil de ser controlada. Com este cenário aliado às condições favoráveis para produção, o bioma Cerrado corre sérios riscos de perder sua vegetação nativa e culminar em um cenário de descaracterização total da sua fauna, flora, comunidades rurais, quilombolas e indígenas.

O profissional da agronomia e técnicos da área precisam fazer a adoção de medidas menos predatórias aos recursos naturais e isso só é possível por meio de um processo de desconstrução e ressignificação das etapas de produção, especialmente o preparo da área o manejo. 0 ideal é planejar muito bem as atividades para que a tomada de decisão possibilite o aproveitamento máximo do potencial produtivo da terra sem que haja esgotamento dos recursos do meio.

A agricultura precisa avançar para conseguir suprir a demanda por alimento e matéria prima, mas isso não exclui a necessidade de conservação de áreas com vegetação nativa. Se a atividade agrícola precisa produzir para manter a população viva, matar um bioma tão representativo para o Brasil, como é o caso do Cerrado, está na contramão da sustentação da existência do próprio ser humano. É necessário produzir cada vez mais e o agronegócio precisa avançar, todavia, essa expansão precisa urgentemente primar por não esgotar os recursos naturais. 


\section{CONSIDERAÇÕES FINAIS}

De acordo com o que a pesquisa, são perceptíveis os impactos ambientais e sociais sofridos pelo constante desmatamento nos estados do MATOPIBA para os fins agrícola e agropecuário. Impactos esses são decorrentes da má administração governamental que não dispõe de leis, normas e decretos vigentes para a proteção e controle ambiental da área. Visto tais pontos, observa-se uma grande necessidade de reativação perante correção de lacunas jurídicas que tornem o decreto, do Plano de Desenvolvimento Agropecuário do MATOPIBA mais eficaz e com enfoque também na proteção ambiental e preservação do bioma Cerrado.

Além disso, são necessárias medidas de proteção que impeçam o desmatamento em terras indígenas, criação de áreas de preservação permanente, demarcação do território, assim como ampliação de programas de desenvolvimento social agrícola para os pequenos produtores da região. 0 que se espera são ações do poder público, para fiscalizar, punir e consequentemente retardar o desmatamento, de forma a não prejudicar o agronegócio, meio ambiente e produção familiar.

\section{REFERÊNCIAS}

AgRosATÉlite GEOTECNOLOGIA APLICADA Ltda. Análise Geoespacial da Dinâmica das Culturas Anuais no Bioma Cerrado: 2000 a 2014. Rudorff, B.; Risso, J. et al., 2015 Florianópolis, Santa Catarina, Brasil, 2015.

Agrosatélite geoteCnOlOGiA APliCADA Ltda. Análise Geoespacial da Soja no Bioma Cerrado: Dinâmica da Expansão | Aptidão Agrícola da Soja | Sistema De Avaliação Para Compensação Financeira: 2001 a 2019. Florianópolis, 2020.

AGUIAR, Adriano Saraiva. Modelagem da dinâmica do desmatamento na região do MATOPIBA até 2050. 2016.

APROSOJA BRASIL. Posicionamento sobre a produção de soja no Matopiba. 11 de jun. $2019 . \quad$ Disponível em: $<$ https://aprosojabrasil.com.br/comunicacao/blog/2019/07/10/posiciona mento-sobre-a-producao-de-soja-no-matopiba/>. Acesso em: 17 de jun. 2021.

ASSOCIAÇÃO DE AGRICULTORES E IRRIGANTES DA BAHIA - AIBA. Principais culturas. AIBA, 2018. Disponível em: < https://aiba.org.br/principaisculturas/>. Acesso em: 28 de jun. 2021. 
BORGHI, E. et al. Desafios das novas fronteiras agrícolas de produção de milho e sorgo no Brasil: desafios da região do MATOPIBA. In: KARAM, D.; MAGALHÃES, P. C. (Ed.). Eficiência nas cadeias produtivas e o abastecimento global. Sete Lagoas: Associação Brasileira de Milho e Sorgo, 2014. cap. 25, p. 263-278. P. 263-278.

CASTRO, C. N. A agricultura no Nordeste brasileiro: oportunidades e limitações ao desenvolvimento. Rio de Janeiro: Ipea, 2012.

CERDAS, G. A dupla serpente: Estado e agroindústria sucroenergética brasileira na construção de uma nova matriz de inserção global (2003 2014). Tese (Doutorado em Ciências Sociais). Programa de Pós-Graduação de Ciências Sociais em Desenvolvimento, Agricultura e Sociedade, Instituto de Ciências Humanas e Sociais, Universidade Federal Rural do Rio de Janeiro. Rio de Janeiro, 2015.

EMBRAPA. MATOPIBA. Disponível em: https:<//www.embrapa.br/temamatopiba/sobre-o-tema>. Acesso em: 16 de jun. 2021.

EMPRESA BRASILEIRA DE PESQUISA AGROPECUÁRIA - EMBRAPA. Evolução e Qualidade da Pecuária Brasileira. Brasília, DF. 2017.

FEDERAÇÃO DA AGRICULTURA E PECUÁRIA DO ESTADO DO TOCANTINS. PIB tocantinense para 2018 é de aproximadamente $R \mathbf{\$ 3 2 , 3}$ bilhões. FAETRURAL, 2018. Disponível em: <http://www.faetrural.com.br/noticias1317-pib-tocantinense-para-2018-e-de-aproximadamente-r-32-3bilhoes.html>. Acesso em: 28 de jun. 2021.

FERREIRA, Y. C.; MARQUES, J. M. G. A expansão agrícola e a produção de alimentos no estado do Tocantins. IX Simpósio da Pós-Graduação em Ciência do Sistema Terrestre. Instituto Nacional de Pesquisas Espaciais, São José dos Campos, 2020.

Greenpeace Brasil. Desmatamento do Cerrado se concentrou no MATOPIBA. Disponível em: <https://www.greenpeace.org/brasil/blog/desmatamentono-cerrado-se-concentrou-no-matopiba/> Acesso em: 16 de jun. 2021.

GREENPEACE. Desmatamento no Cerrado se concentrou no Matopiba. Greenpeace $\quad$ Brasil, 2019. Disponível em: < https://www.greenpeace.org/brasil/blog/desmatamento-no-cerrado-seconcentrou-no-matopiba/>. Acesso em: 29 de jun. 2021.

IBGE. Instituto Brasileiro de Geografia e Estatística. Manual Técnico de Uso da Terra. Rio de Janeiro, 2013.

INSTITUTO NACIONAL DE PESQUISAS ESPACIAIS, INPE. Coordenação Geral de Observação da Terra. Prodes - Incremento anual de área desmatada no Cerrado Brasileiro. Disponível em: <http://www.obt.inpe.br/cerrado>. Acesso em 18 jun. 2021. 
LIMA, T. P. DINÂMICA ESPAÇO-TEMPORAL DAS ALTERAÇÕES GEOESPACIAS NA REGIÃO DO MATOPIBA, BRASIL. Urutaí, 2020.

MAPA - Ministério da Agricultura, Pecuária e Abastecimento. Assessoria de Gestão Estratégica. Projeções do Agronegócio - Brasil 2015/2016 a 2025/2026: Projeções de Longo Prazo. Brasília, 2016. 41p.

MIRANDA, E. E. et al. Proposta de Delimitação Territorial do MATOPIBA. 2014. Disponível em: <https://www.embrapa.br/gite/publicacoes/NT1_Delimitac aoMatopiba.pdf>. Acesso em: 17 de jun. de 2021.

MUELLER, C.; MARTHA JÚNIOR, G. A agropecuária e o desenvolvimento socioeconômico recente do cerrado. FALEIRO, F.G; NETO, A.L.F. Savanas: desafios e estratégias para o equilíbrio entre sociedade, agronegócio e recursos naturais, Planaltina, DF: Embrapa Cerrados, 2008. p.104 - 169.

NOBREGA, R. et al. Effects of conversion of native cerrado vegetation to pasture on soil hydrophysical properties,evapotranspiration and streamflow on theAmazonian agricultural frontier, 2017.

NOOJIPADY, P. et al. Forest carbon emissions from cropland expansion in the Brazilian Cerrado biome. Environmental Research Letters, v.12, p. 1-11, 2017.

OBSERVATÓRIO ABC. Invertendo o Sinal de Carbono da Agropecuária Brasileira - Uma Estimativa do Potencial de Mitigação de Tecnologias do Plano ABC de 2012 a 2023. Relatório 5. São Paulo. p.114. Ano 2015.

OBSERVATÓRIO DO CLIMA. Análise da evolução das emissões de GEE no Brasil (1990- 2012). São Paulo: Observatório do Clima, 2014.

OLIVEIRA, L. C. Matopiba uma região em desenvolvimento. 2020.

OLIVEIRA, Raquel; THEOPHILO, Leide. No Tocantins, o Agro se destaca e mostra força em 2020. Governo do Tocantins - SEAGRO, 2021. Disponível em: < https://www.to.gov.br/seagro/noticias/no-tocantins-o-agro-se-destaca-emostra-forca-em-

2020/3puyfh33ydpl\#: :text=A\%20produ\%C3\%A7\%C3\%A3o\%20estabele cida\%20projetada\%20pela,29\%25\%20superior\%20ao\%20de\%202019.>. Acesso em: 28 de jun. 2021.

PEDROSA, R. Produção agrícola do Piauí tem o segundo maior crescimento do país em 2021, segundo IBGE. Governo do Estado do Piauí, 2021. Disponível em: $\quad<$ https://www.pi.gov.br/noticias/producao-agricola-do-piaui-tem-osegundo-maior-crescimento-do-pais-em-2021-segundo-ibge/>. Acesso em: 28 de jun. 2021.

PENA, R. A. Fronteira Agrícola no Brasil. Disponível em: $<$ http://alunosonline.uol.com.br/geografia/fronteira-agricola-nobrasil.html>. Acesso em: 22 jun. 2021. 
PEREIRA, C. N.; CASTRO, C. N.; PORCIONATO, G. L. Aspectos socioeconômicos da região do Matopiba. Boletim Regional, Urbano e Ambiental (IPEA), v.18, p.47-59, 2018.

PEREIRA, C. N.; PORCIONATO, G. L.; CASTRO, C. N. Aspectos socieconômicos da região do Matopiba. 2018.

PITTA, F. T.; VEGA, G. C.; BARBORA, S. Impactos da expansão do agronegócio no Matopiba: Comunidades e Meio Ambiente. In ActionAid, Rede Social de Justiça e Direitos Humanos, Ford Foundation, 2017.

Presidência da República. Decreto no 10.473, de 24 de agosto de 2020. Disponível em: <http://www.planalto.gov.br/ccivil_03/_Ato20192022/2020/Decreto/D10473.htm\#art1> Acesso em: 17 de jun. 2021.

RIBEIRO, T. F. Da MP 759 a Lei 13.465/17: os novos rumos da regularização fundiária no Brasil. 2020 Disponível em: < https://www.observatoriodasmetropoles.net.br/da-mp-759-lei13-465-17-os-novos-rumos-da-regularizacao-fundiaria-nobrasil/>. Acesso em: 26 de jun. 2021.

SALOMON, M. M. R. Quem disputa o Matopiba? Interesses e sustentabilidade na fronteira agrícola. 2020.

SANTOS, R. M. A intensificação da bovinocultura de corte como um instrumento na redução do desmatamento nos diferentes biomas brasileiros. 2018.

SECRETARIA DE ESTADO DE PROGRAMAS ESTRATÉGICOS - SEPE. Maranhão bate recorde em produção de grãos em 2020. Governo do Maranhão - SEPE, 2020. Disponível em: < http://sepe.ma.gov.br/maranhao-bate-recorde-emproducao-de-graos-em-2020/>. Acesso em: 28 de jun. 2021.

SILVA, P. R. F. (2020). A expansão agrícola no Cerrado e seus impactos no ciclo hidrológico: estudo de caso na região do MATOPIBA. Dissertação de Mestrado em Desenvolvimento Sustentável. Centro de Desenvolvimento Sustentável. Universidade de Brasília. Brasília, DF, 155 p. 


\section{CAPÍTULO IV}

\section{PERCEPÇÃO DE ALUNOS DOS CURSOS DE AGRONOMIA E ENGENHARIA AMBIENTAL SOBRE AS LEIS AMBIENTAIS}

DOI: 10.51859/amplla.lar559.1121-4

Heloiza Rodrigues Silva

Universidade Estadual do Maranhão - UEMA, Centro de Ciências Agrárias - CCA, Campus São Luís/MA, Brasil

E-mail: heloizasilva1@aluno.uema.br

Erick Felipe dos S. Sales

Universidade Estadual do Maranhão - UEMA, Centro de Ciências Agrárias - CCA, Campus São Luís/MA, Brasil

E-mail: erick_14felipe@hotmail.com

Airton Watanabe de S. Oliveira

Universidade Estadual do Maranhão - UEMA, Centro de Ciências Agrárias - CCA, Campus São Luís/MA, Brasil E-mail: airtonwatanabesansei@gmail.com

Nathalia da Luz Oliveira

Universidade Estadual do Maranhão - UEMA, Centro de Ciências Agrárias - CCA, Campus São Luís/MA, Brasil E-mail: nathalia.arievilo@hotmail.com

Raiza Sousa Farias

Universidade Estadual do Maranhão - UEMA, Centro de Ciências Agrárias - CCA, Campus São Luís/MA, Brasil

E-mail: piresraiza1@gmail.com

Camila Alexandre Cavalcante de Almeida

ORCID: https://orcid.org/0000-0002-2989-8243 Universidade Federal de Alagoas - UFAL, Campus de Engenharias e Ciências Agrárias - CECA, Brasil E-mail: mil.la.m@hotmail.com

Denise Maria Santos

ORCID: https://orcid.org/0000-0001-8886-6439 Instituto Dom José de Educação e Cultura IDJ/UVA, Brasil.

E-mail: deniseufc@yahoo.com.br

Andréa de Vasconcelos Freitas Pinto

ORCID: https://orcid.org/0000-0002-9306-418X Universidade Federal de Alagoas - UFAL, Campus de Engenharias e Ciências Agrárias - CECA, Brasil E-mail: dea_botelho@hotmail.com

Maria José de Holanda Leite

ORCID: https://orcid.org/0000-0003-4154-3901

Universidade Estadual do Maranhão - UEMA, Centro de Ciências Agrárias - CCA, Campus São Luís/MA, Brasil E-mail: maryholanda@gmail.com

\section{RESUMO}

O licenciamento ambiental é importante para a preservação, melhoria e recuperação da qualidade ambiental, que é essencial para a vida, visando garantir condições para um desenvolvimento socioeconômico e à proteção da dignidade da vida humana. A legislação ambiental tem papel fundamental para que aconteça a sustentabilidade e preservação ambiental, através da legislação ambiental é possível garantir que as empresas ajustem suas práticas para proteger os recursos naturais. 0 objetivo da pesquisa foi analisar diferentes pontos de vista dos estudantes, observando resultados positivos e negativos em relação à sensibilização deste mediante aos temas e leis ambientais. A pesquisa ocorreu com estudantes dos cursos de engenharia agronômica e ambiental a partir do 5o período visando entender seus pontos de vista em relação a preocupação com o meio ambiente nos dias atuais e utilizou-se de pesquisas bibliográficas e aulas virtuais da disciplina de Legislação, 
Política Agrária e Ambiental como suporte para o levantamento da pesquisa. 0 estudo tratou-se de uma pesquisa para analisar em meio aos dias atuais, como está às perspectivas dos estudantes de Agronomia e Engenharia Ambiental em relação às normas ambientais em meio a uma sociedade que busca mais fins lucrativos e menos se preocupa com o meio ambiente com estudantes que futuramente serão inseridos no mercado de trabalho. A preservação dos recursos naturais é um importante fator que contribui para manter a qualidade de vida de todos os indivíduos existentes. Como conclusão da presente pesquisa, fica notável a falta da existência uma educação ambiental adequada nos cursos analisados. Assim, sugerese maior atenção do Poder Público juntamente com o Ministério da Educação para tornar obrigatória a Educação ambiental como via de conscientização, para que a sociedade tenha o chamado choque de realidade da real situação o qual o nosso planeta vive, a exemplo da degradação dos recursos naturais.

Palavra-chave: código florestal; sustentabilidade; meio ambiente.

\section{INTRODUÇÃO}

A legislação ambiental desempenha um papel importante no desenvolvimento sustentável. Porque é uma forma legal de exigir que as empresas ajustem suas práticas para proteger os recursos naturais. Além de evitar danos à natureza e às comunidades que vivem no entorno da base produtiva da organização, o cumprimento das regulamentações ambientais beneficia as empresas e a população no geral. Vale ressaltar que, o objetivo do licenciamento é a preservação, melhoria e recuperação da qualidade ambiental propícia à vida, visando assegurar condições ao desenvolvimento socioeconômico, aos interesses da segurança nacional e à proteção da dignidade da vida humana (BRASIL, 2009).

A legislação ambiental inclui leis, decretos e resoluções as quais são destinadas a estabelecer regras para as operações da empresa e o comportamento ambiental dos cidadãos. Essas disposições legais também estipulam violações e penalidades para o não cumprimento da lei (AMBSCIENCI). Cada pessoa tem diferentes percepções, contraposições e reações às ações sobre o ambiente. A reação ou desempenho é o resultado da percepção, processo cognitivo, julgamento e expectativa de cada pessoa. Essas manifestações geralmente afetam o comportamento inconscientemente. Assim, a percepção ambiental pode ser definida como sendo uma tomada de consciência do ambiente pelo ser humano, ou seja, o ato de perceber o ambiente que se está inserido (FAGGIONATO, 2002).

O ser humano tem a necessidade de modificar o meio de acordo com o seu objetivo, mas para isso se é necessário ter o conhecimento sobre a área que será 
usada, ter conhecimento sobre se é uma área de preservação ambiental ou não, para que não venha a acarretar problemas futuros, tanto ao meio ambiente, como a si próprio. Os órgãos ambientais, tais como: Conselho Nacional do Meio Ambiente (CONAMA), Instituto Brasileiro do Meio Ambiente e dos Recursos Naturais Renováveis (IBAMA), Ministério do Meio Ambiente, dentre outros, são responsáveis pela fiscalização de obras em locais indevidos, assim como muitas outras violações que são feitas na natureza. Eles tanto fiscalizam como aplicam as punições aos infratores (DINÂMICA AMBIENTAL, 2017)

Nesse sentido, o Código Florestal modificado em 2012 proporcionou anistia a alguns fazendeiros operando em áreas desmatadas ilegalmente, isso infelizmente torna mais difícil a criação de políticas públicas que poderão aplicar punições severas a essas pessoas. Antes de qualquer busca rápida por dinheiro nessa área, deve-se levar em conta o futuro do planeta como um todo.

De modo que, ter o conhecimento acerca de como funciona as leis ambientais do país, quais os benefícios e as obrigações que elas regem, é de estrema importância. 0 cidadão tem que abranger mais seu conhecimento a cerca deste tema tão relevante, não deixando apenas restrito ao conhecimento de quem o estuda em especial, para que não ocorram crimes ambientais tão recorrentes. Em seu Art. № 225 , todos têm direito ao meio ambiente ecologicamente equilibrado, bem de uso comum do povo e essencial à sadia qualidade de vida, impondo-se ao poder público e à coletividade o dever de defendê-lo e preservá-lo para as atuais e futuras gerações. 0 ter direito, não aboliu a responsabilidade para com o meio ambiente, não é fazer dele o que se bem entender. Assim como se tem o direito de ter, se tem o direito de preservar e proteger. 0 poder público junto com a sociedade, têm que trabalharem juntos, para manter-se seguro o meio ambiente o máximo que puder, pois muitas gerações estão por vim e a mesma necessitará da natureza para sobreviver.

Tendo em vista a relevância do tema, a presente pesquisa teve como objetivo entender a percepção de estudantes dos cursos de agronomia e engenharia ambiental sobre aplicabilidade de normas ambientais para com a sociedade. Contudo, o principal meio para atingir o objetivo de aplicabilidade das normas legais ambientais se dá por controle e orientações assim exercendo o cumprimento das normas jurídicas, diante disso, sem causar danos à sociedade e proporcionando o 
principal que é a proteção do meio ambiente como um todo e nas orientações de outras áreas que utilizam do meio ambiente para trabalho de forma direta ou indireta.

\section{MATERIAL E MÉTODOS}

A pesquisa ocorreu com estudantes dos cursos de engenharia agronômica e ambiental a partir do 5ำ período visando entender seus pontos de vista em relação a preocupação com o meio ambiente nos dias atuais e utilizou-se de pesquisas bibliográficas e aulas virtuais da disciplina de Legislação, Política Agrária e Ambiental como suporte para o levantamento da pesquisa.

O estudo tratou-se de uma pesquisa para analisar em meio aos dias atuais, como está às perspectivas dos estudantes de Agronomia e Engenharia Ambiental em relação às normas ambientais em meio a uma sociedade que busca mais fins lucrativos e menos se preocupa com o meio ambiente com estudantes que futuramente serão inseridos no mercado de trabalho. Quanto ao problema, a pesquisa caracterizou-se como qualitativa e quantitativa e teve como instrumentos de pesquisa um questionário elaborado pela equipe através da plataforma Google, sendo composto por onze questões. 0 questionário foi aplicado de forma online para os acadêmicos por meio de plataformas como Whatsapp e Instagram.

O instrumento contou com perguntas baseadas em: I. Constituição brasileira de 1988; II. Práticas e ações rotineiras que ajudam a preservar o meio ambiente; III. Fiscalização ambiental do Poder Público; IV. Agronegócio e desmatamento ilegal e V. Desenvolvimento sustentável; X Severidade das leis ambientais. As perguntas baseadas no tópico I consistem em identificar qual o grau de importância da preservação do meio ambiente. 0 tópico II tem por finalidade captar as práticas utilizadas no dia a dia para preservar o meio ambiente. Pois é possível analisar se a importância com boas práticas ambientais fica somente na teoria ou se realmente é colocada em prática.

Por fim, fez-se as análises das respostas do questionário aplicado, e em seguida os dados foram compilados e organizados em gráficos de pizza, com o auxílio da plataforma do Google Forms. 


\section{RESULTADOS E DISCUSSÃO}

Para a realização da pesquisa, foi necessária à coleta de dados de estudantes do curso de engenharia agronômica e ambiental, com o total de 23 participantes. Cerca de 34,8 \% eram do curso de engenharia ambiental e 65,2 \% são do curso de engenharia agronômica (Figura 1), sendo cursos com pontos de vista diferentes em muitos aspectos, mas em outros com visões bastante semelhante sobre a legislação ambiental e sustentabilidade.

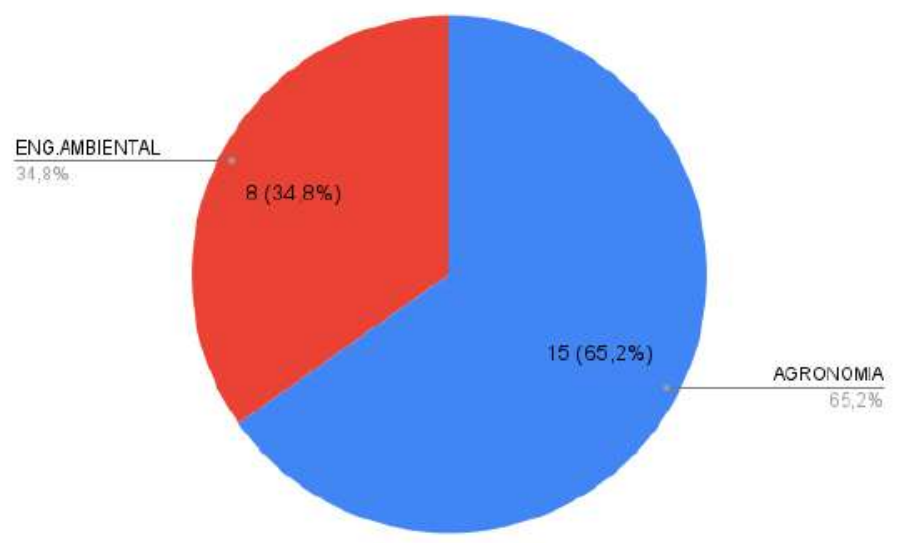

Figura 1. Qual curso você faz?

Fonte: Os autores.

Em pleno século 21, ainda é possível ver que tem pessoas que não se importam com o meio ambiente, como apresentado no gráfico apesar do número maior ser positivo, ainda 4,3\% acham irrelevante esse assunto (Figura 2). Sabe-se que, existe uma diferença clara entre o discurso e a prática. Falar que se importa é uma coisa, mas de fato ter uma mudança de comportamento é outra história. Somos um dos países com maiores índices de desmatamento, reciclamos menos de 5\% dos nossos resíduos e elegemos governos com claro descaso por questões ambientais (UNIMED, 2019). Nesse sentido, pode-se compreender que os números não conseguem nos comprovar que verdadeiramente exista uma preocupação maior com meio ambiente, mas somente a necessidade de se fazer entender que essa preocupação existe. 


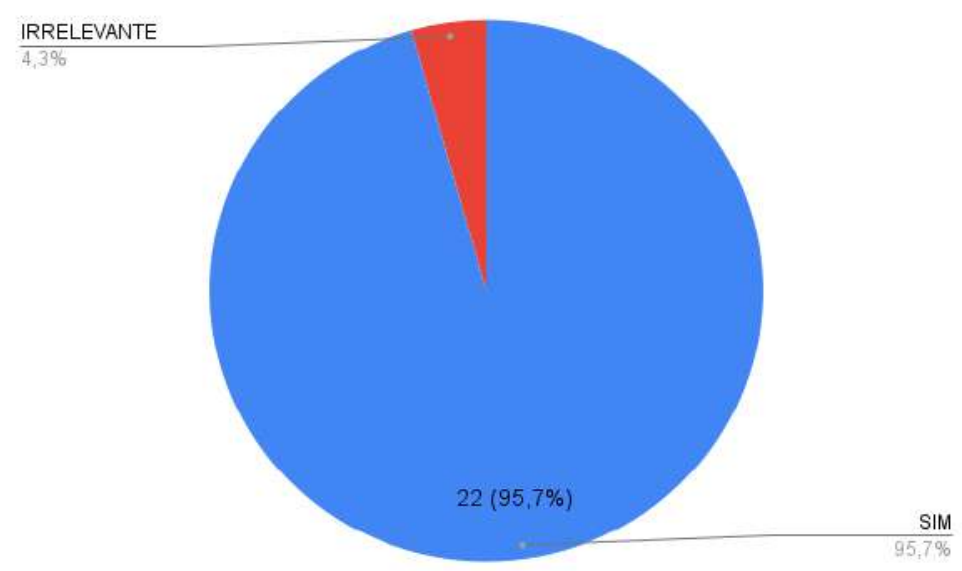

Figura 2. Importância da preservação do meio ambiente.

Fonte: Os autores.

Constata-se que 73,9\% dos entrevistados adotam práticas para redução dos danos ambientais, porém $26,1 \%$ dos entrevistados não adotam práticas rotineiras de preservação (Figura 3). Vale destacar que, cenário ambiental atual necessita de soluções imediatas (ALENCAR et al., 2015). Faz-se necessário que a comunidade reconheça como parte constituinte do meio ambiente e que transforme sua visão em relação aos problemas ambientais. Silva e Leite (2008, apud Alencar, 2015): “ afirmam que, a percepção inadequada da realidade promove a utilização dos recursos ambientais de maneira insustentável, comprometendo a estabilidade ambiental e social ".

É importante relatar que, a sensibilização contínua é imprescindível para a formação da consciência ecológica dos alunos (GOMES et al., 2018). E, que devem ser sensibilizados em todas as etapas de sua formação garantindo a eficácia na preservação e conservação do meio ambiente. Sendo que a melhor metodologia é inserir os alunos ativamente no processo de ensino aprendizagem. 


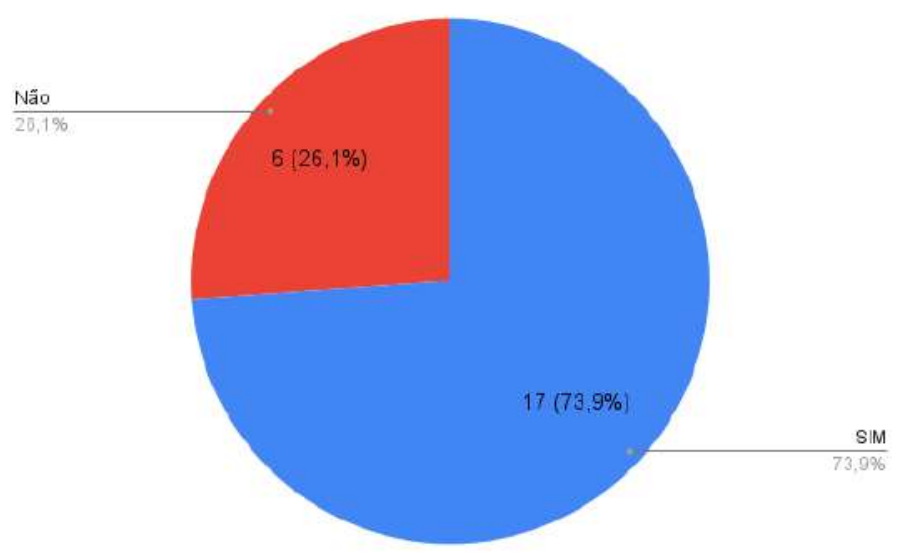

Figura 3. Aplicação de atividades práticas para redução de danos ambientais.

Fonte: Os autores

De acordo com a opinião dos entrevistados, 78,3 \% (Figura 4), consideram que o poder público não fiscaliza e disciplina para o cumprimento das normas ambientais, em contrapartida cerca de $21,7 \%$, acreditam que o poder público cumpre com o seu papel de fiscalizar e punir. É sabido que, o exercício de fiscalização é papel do Poder Público que tem o dever de fiscalizar as condutas das pessoas que se apresentem como seres degradadores e utilizadores dos recursos naturais de forma desenfreada como forma de garantir a preservação do meio ambiente para a coletividade (IBAMA, 2016).

As pessoas que praticam o desmatamento ilegal com base no retorno econômico são maiores que as punições e os valores das infrações (SCHMITT, 2015). A efetividade da fiscalização ambiental para o controle do desmatamento ilegal na Amazônia é muito baixa e isso é devido à limitada capacidade punitiva. Com isso diz que se fazem necessárias punições mais severas, porque mesmo que legislação estabeleça penas e multas, existem lentidão na aplicação dos processos penais e recursos que facilitam a vida dos infratores, contribuindo assim para sensação de impunidade. 


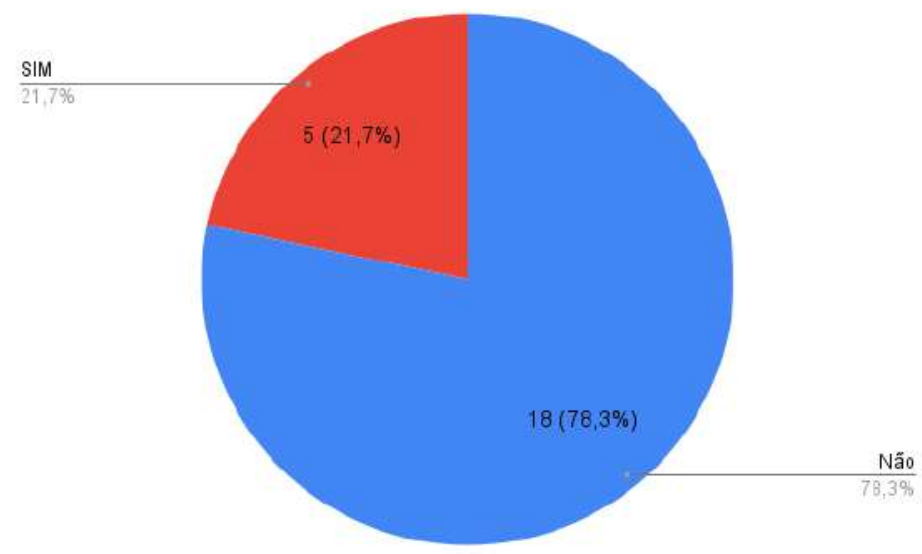

Figura 4. O poder público fiscaliza e disciplina em relação ao cumprimento das normas ambientais.

Fonte: Os autores

Pode-se observar na figura 5, que 95,7 \% dos entrevistados, responderam que as severidades em relação às punições devem ser maiores, visto que o meio ambiente e o seu conjunto são recursos nos quais os seres humanos devem e necessitam proteger e ter consciência que as futuras gerações possam usufruir desse bem, que é de todos nós. Em divergência 4,3 \% objetaram em suas respostas que não apresentam muita importância.

Schmitt (2015), afirma que: “Contudo, essa redução poderia ser maior se algumas medidas propostas fossem implementadas, tais como: aumento da capacidade de execução das sanções, especialmente o pagamento das multas e a destinação de bens apreendidos; redução do tempo de julgamento das infrações ambientais; aumento da capacidade de apreensão dos bens envolvidos em infrações ambientais". Dessa maneira, faz-se necessárias e obrigatórias medidas mais severas que não se aplique apenas na teoria e que sejam colocadas em práticas punindo aqueles praticam crimes ambientais.

Sabe-se que, a Constituição Federal reconhece sua autonomia do bem jurídico em relação ao meio ambiente, que ligadas aos recursos ambientais constituintes, sendo assim, um bem de uso comum do povo (CAPELLI, 2019). Afirmando que o meio ambiente é um bem público, insuscetível de apropriação privada, cujo usufruto, com os qualificativos de higidez e equilíbrio ecológico, é garantia da população brasileira. E não é dever somente da comunidade, mas ela deve ter a obrigação de preservar o meio ambiente. 


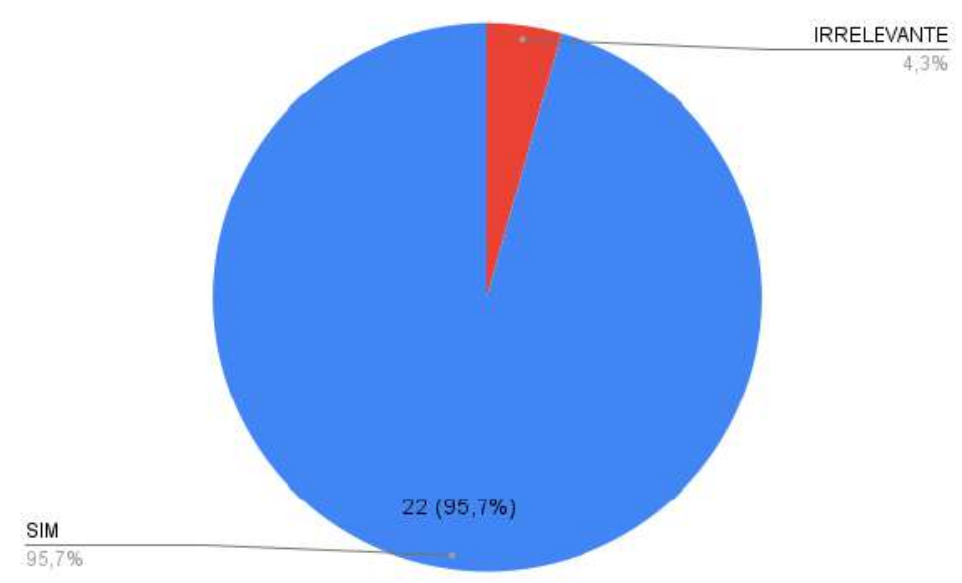

Figura 5. Grau de severidade maior em relação às leis ambientais.

Fonte: Os autores

Constata-se que 60,9\% dos entrevistados consideram que o agronegócio ainda é o maior causador do desmatamento ilegal, em contrapartida um percentual de 39,1 \% respondeu que o agronegócio não é um veículo causador do desmatamento ilegal (Figura 6). No entanto, segundo dados da pesquisa realizada por Menegassi (2021), mais de dois terços das florestas tropicais do mundo exploradas pelo agronegócio entre 2013 e 2019 foi devastado de forma ilegal para a produção de itens como carne bovina, soja e óleo de palma. Os dados obtidos por meio de um estudo divulgado pela Forest Trends revelam que o agronegócio foi o motor de $60 \%$ de toda área florestal perdida no planeta, o equivalente a 46,1 milhões de hectares, da qual 69\% foram desmatadas de forma ilegal, o que corresponde a 32 milhões de hectares.

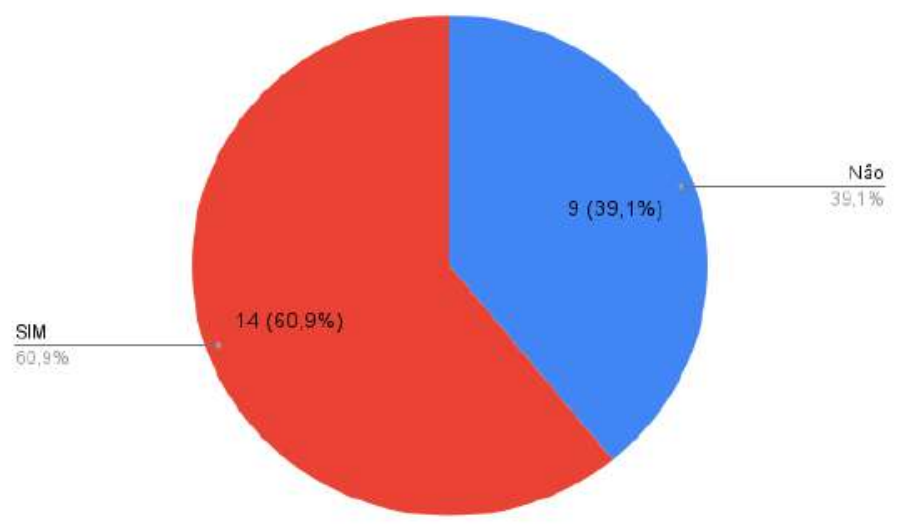

Figura 6. 0 agronegócio é o maior causador do desmatamento ilegal.

Fonte: Os autores. 
Vale ressaltar que, a agricultura sustentável consiste na utilização do ecossistema agrícola e o manejo, para manutenção da sua atividade biológica, vitalidade, capacidade de regeneração, habilidade de funcionamento, para a preservação atual e no futuro, com funções ecológicas, econômicas e sociais no âmbito local, nacional e global, e não cause danos em outros ecossistemas (LEWANDOWSKI et al., 1999). A prática de uma agricultura sustentável é algo que já está na realidade no contexto atual de produção do agronegócio, abandonando-se as práticas convencionais do agronegócio, e adotando a sustentabilidade, como mostrado na figura 7 , cerca de $91,3 \%$ acreditam que eles podem caminhar juntos para a sustentabilidade e uma pequena parte $8,7 \%$ não veem progresso nessa união.

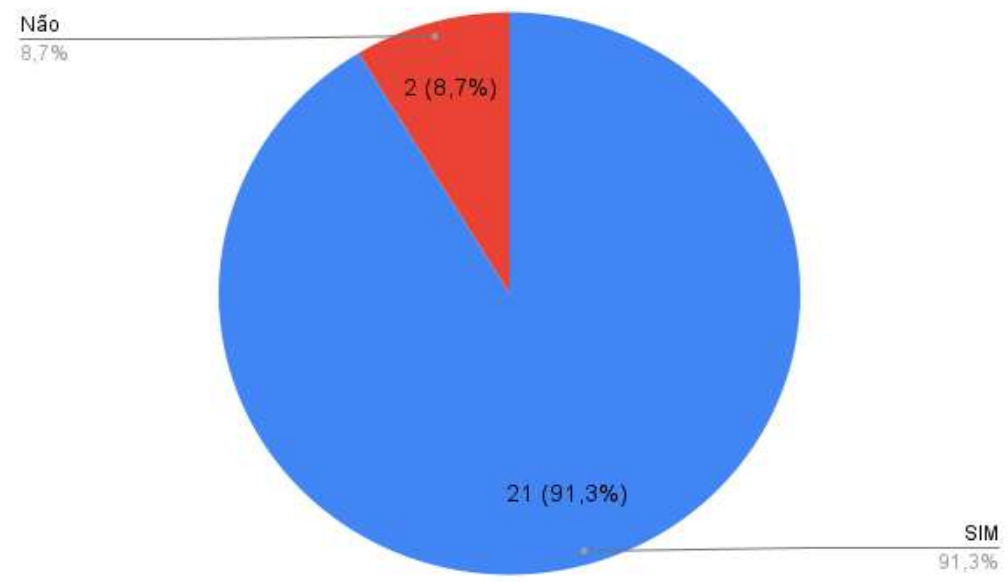

Figura 7. Agronegócio e o desenvolvimento sustentável podem se desenvolver de forma amigável.

Fonte: Os autores

A preservação do ecossistema é um importante fator que contribui para manter a qualidade de vida de todos os indivíduos existentes. A adoção de práticas e ações rotineiras tende a evitar danos ambientais, dessa maneira contribuindo com a sustentabilidade. No entanto, não basta apenas adotar essas práticas, é necessário que o poder público coloque em prática, principalmente no quesito da fiscalização no cumprimento das normas legais ambientais proposta a sociedade. 0 Ministério Público, ao lado do Poder Público, além de ter a missão institucional de fiscalizar o cumprimento da lei, tem a incumbência de zelar pelos interesses difusos, dentre eles o meio ambiente. Assim, possui a seu favor ferramentas que permitem a investigação e a regularização de condutas reprováveis do ponto de vista legal. 0 
poder público é detentor dos principais instrumentos de fiscalização ambiental. 0 que se percebe é a falta de estrutura para exercer a competente fiscalização. Com isso, os problemas ambientais acabam passando despercebidos pelos olhos do Estado, revelando a omissão e, em algumas situações, convivência com problemas ambientais.

Dessa forma, a conscientização e o ativismo de todos os setores da sociedade é fundamental para se obter sucesso no desenvolvimento sustentável, uma vez que ele se dá por ações que devem ser tomadas em todas as esferas da sociedade, sejam elas de caráter individual, sociedade e poder público. Assim, a educação ambiental e o cumprimento das leis ambientais são capazes de aproximar as pessoas da natureza e fazê-las compreender todo o grau de importância de se preservar agora e não depois. Que o respeito e solidariedade contribuem muito e é um passo importante para alcançar outros e fazer assim eles entenderem que os que causam hoje, podem sofrer amanhã. Mas aqueles que contribuírem hoje, terão bons frutos.

\section{CONCLUSÃo}

Como conclusão da presente pesquisa, fica notável a falta da existência uma educação ambiental adequada nos cursos analisados. Assim, sugere-se maior atenção do Poder Público juntamente com o Ministério da Educação para tornar obrigatória a Educação ambiental como via de conscientização, para que a sociedade tenha o chamado choque de realidade da real situação o qual o nosso planeta vive, a exemplo da degradação dos recursos naturais.

\section{REFERÊNCIAS}

FAgGiOnATO, Sandra. Percepção ambiental. Texto disponibilizado em 2002. Disponível em:<http://educar.sc.usp.br/biologia/textos/m_a_txt4.html >. Acesso em: 03 de abr. de 2008.

AMBSCIENCI. Legislação Ambiental. Disponível em: https://ambscience.com/legislacao-ambiental/. Acesso em: 12 jun. 2021.

DINÂMICA AMBIENTAL. Saiba quais são os órgãos fiscalizadores do meio ambiente e suas responsabilidades. Disponível em: https://www.dinamicambiental.com.br/blog/meio-ambiente/saiba-saoorgaos-fiscalizadores-meio-ambiente-responsabilidades/. Acesso em: 12 jun. 2021. 
POLITIZA. Ministério do Meio Ambiente. Disponível em: https://www.politize.com.br/ministerio-do-meioambiente/\#: :text=\%C3\%89\%20de\%20responsabilidade $\% 20 \mathrm{do} \% 20$ Minis t\%C3\%A9rio,ambiente\%20dentro\%20do\%20territ\%C3\%B3rio\%20brasile iro.. Acesso em: 12 jun. 2021.

SCIENTIFIC AMERICAN BRASIL. Agronegócio é o maior responsável pelo desmatamento ilegal. Disponível em: https://sciam.com.br/agronegocio-eo-maior-responsavel-pelo-desmatamento-ilegal/. Acesso em: 12 jun. 2021.

SENADO FEDERAL. Art. 225. Disponível em: https://www.senado.leg.br/atividade/const/con1988/con1988_26.06.201 9/art_225_.asp. Acesso em: 12 jun. 2021.

ZAG0, Juliane Pereira; ROCHA, Marcelo Borges; COSTA, P. M. M. D. Percepção de estudantes de Engenharia Ambiental sobre a contribuição das atividades extraclasse em sua formação acadêmico-profissional. Terra e Didática, Campinas-SP, v. 16, n. 020033, p. 1-12, mar./2020. Disponível em: https://periodicos.sbu.unicamp.br/ojs/index.php/td/article/view/865979 1/23052. Acesso em: 12 jun. 2021.

IBAMA. 0 que é fiscalização ambiental. Disponível em: http://www.ibama.gov.br/fiscalizacao-ambiental/o-que-e-fiscalizacao. Acesso em: 10 jun. 2021.

O ECO. Relatório expõe agronegócio como grande motor do desmatamento ilegal de florestas. Disponível em: https://www.oeco.org.br/noticias/relatorio-expoe-agronegocio-comogrande-motor-do-desmatamento-ilegal-de-florestas/. Acesso em: 11 jun. 2021.

BRASIL. Ministério do Meio Ambiente. Programa Nacional de Capacitação de Gestores Ambientais: caderno de licenciamento ambiental. Brasília, DF, $2009 . \quad$ Disponível em: http://www.mma.gov.br/estruturas/dai_pnc/_arquivos/pnc_caderno_licen ciamento_ambiental_01_76.pdf. Acesso em: 18 junho 2021.

BRK AMBIENTAL. Enchentes no Brasil: impactos do descarte incorreto do lixo e da falta de saneamento. Saneamento, sociedade e meio ambiente. Disponível em: < https://blog.brkambiental.com.br/enchentes-no-brasil/>. Acesso em: 20 de Junho de 2021.

PEREIRA, S. S.; CURI, R. C. Meio Ambiente, Impacto Ambiental e Desenvolvimento: conceituações Teóricas sobre o Despertar da Consciência Ambiental. Universidade Federal de Campina Grande. Revista de Administração, Contabilidade e Sustentabilidade. Campina Grande, Paraíba. Vol. 2, no 4, p.35-57, Set-Dez/2012.

UNIMED. Por que a maioria das pessoas não se importa com problemas ambientais?. Disponível em: < https://www.unimed.coop.br/web/canal- 
unimed-parana/papo-sutentavel/por-que-a-maioria-das-pessoas-nao-seimporta-com-problemas-ambientais->. Acesso em: 20 de Junho de 2021.

DEUS, R. M. D; BAKONYI, S. M. C. O IMPACTO DA AGRICULTURA SOBRE O MEIO AMBIENTE. REGENT, paraná, v. 7, n. 7, p. 1306-1315, mar./2012. Disponível em: http://dx.doi.org/10.5902/223611705625. Acesso em: 19 jun. 2021.

Alencar, L. D., Barbosa, M. de F. N., \& Barbosa, E. M. (2015). Educação ambiental: análise comparativa dos dados obtidos com os atores sociais de uma escola pública de ensino médio de Campina Grande - PB. REMEA - Revista Eletrônica Do Mestrado Em Educação Ambiental,32(1), 58-78. https://doi.org/10.14295/remea.v32i1.4921 . Acesso em:19 jun.2021

GOMES, J. N. D; SANTOS, L. A. D; APARECIDA, Aline. (2018). Educação ambiental na conscientização e preservação do meio ambiente: unidade escolar Zezita Sampaio, Buriti dos Lopes, PI. Ambiente \&Amp; Educação, 23(1), 225-247. https://doi.org/10.14295/ambeduc.v23i1.6689ciasBRASIL. Acesso em: 19 de jun. 2021. 


\section{CAPÍTULO V}

\section{GESTÃO SOCIOAMBIENTAL E GERENCIAMENTO DOS RESÍDUOS SÓLIDOS DURANTE A PANDEMIA DO COVID-19}

DOI: 10.51859/amplla.lar559.1121-5

Vanessa Kendelly das Neves

Universidade Estadual do Maranhão - UEMA, Centro de Ciências Agrárias - CCA, Campus São Luís/MA, Brasil E-mail: vanessakendelly39@gmail.com

Yasmin Matias Rodrigues

Universidade Estadual do Maranhão - UEMA, Centro de Ciências Agrárias - CCA, Campus São Luís/MA, Brasil E-mail: yasminrodrigues506@gmail.com

Geilson Caldas da Rocha

Universidade Estadual do Maranhão - UEMA, Centro de Ciências Agrárias - CCA, Campus São Luís/MA, Brasil E-mail: geilsonrocha1@aluno.uema.br

Tandy Loyola Rolim

Universidade Estadual do Maranhão - UEMA, Centro de Ciências Agrárias - CCA, Campus São Luís/MA, Brasil

E-mail: loyola.tandy@gmail.com

Gildênia Lima Monteiro

ORCID: https://orcid.org/0000-0002-9858-8783 Universidade Estadual do Maranhão, Campus Colinas/MA, Brasil Centro de Estudos Superiores de Colinas, Brasil

E-mail: gildenia.educ.geo@gmail.com

Amanda de Lira Freitas

ORCID: https://orcid.org/0000-0002-5414-4873 Universidade Federal Rural de Pernambuco - UFRPE, Brasil. E-mail: amanda.27.lira@gmail.com

Carmen Hellen da Silva Rocha

ORCID: https://orcid.org/0000-0002-1674-4050 Instituto Federal do Maranhão - IFMA, Brasil.

E-mail: carmen.rocha@ifma.edu.br

Andréa de Vasconcelos Freitas Pinto

ORCID: https://orcid.org/0000-0002-9306-418X

Universidade Federal de Alagoas - UFAL, Campus de Engenharias e Ciências Agrárias - CCA, Brasil E-mail: dea_botelho@hotmail.com

Maria José de Holanda Leite

ORCID: https://orcid.org/0000-0003-4154-3901 Universidade Estadual do Maranhão - UEMA, Centro de Ciências Agrárias - CCA, Campus São Luís/MA, Brasil E-mail: maryholanda@gmail.com

\section{RESUMO}

Nos tempos atuais, os resíduos sólidos ainda é um assunto que gera muitos problemas, principalmente agora nesse momento caótico em que estamos vivenciando. Os resíduos, independentemente de suas variações, quando descartados de forma incorreta, são considerados um problema para o meio ambiente e um grande desafio para a sustentabilidade. A pandemia do novo coronavírus, além de preocupações econômicas e sociais, trouxe destaque para questões ambientais inerentes a geração resíduos sólidos. Com a aplicação da quarentena, isolamento social e amplo uso dos sistemas de saúde estimam-se elevada geração de resíduos domésticos e de saúde. 0 presente trabalho teve como objetivo analisar a gestão dos resíduos sólidos urbanos durante a pandemia do COVID-19 e as medidas que vem sendo tomadas para a implantação da Política Nacional de Resíduos Sólidos (PNRS) assim como compreender os problemas 
encontrados na gestão de resíduos sólidos. Para coleta de dados, utilizou-se várias pesquisas bibliográficas (artigos científicos, livros), considerados indispensáveis e de estrema importância para o tema em questão, com a finalidade de entender como ocorre a gestão dos resíduos sólidos no Brasil e as medidas que vem sendo tomadas para a implantação da PNRS assim como compreender os problemas encontrados na gestão de resíduos sólidos, e então tomar medidas necessárias para resolver tal problema.

Palavras-chave: Sustentabilidade, Medidas, Política Nacional de Resíduos Sólidos.

\section{INTRODUÇÃ̃o}

A COVID-19 é um dos assuntos mais comentados ultimamente, não somente por ser um vírus que possui alto índice de contaminação, mas também pela capacidade que este tem de permanecer em objetos, aumentando assim seu processo de contaminação. Sabe-se que o coronavírus ele pode ser transmitido pelas vias respiratórias, como espirros, tosses e perdigotos. Mais estudos apontam que o vírus pode permanecer em sua forma ativa em superfícies e objetos contaminados, assim como: plásticos ( 5 dias), papel (4-5 dias), vidro e madeira (4 dias), aço (2 dias), luvas cirúrgicas (8 horas) e alumínio (2-8 horas) (ABRELPE, 2017).

E as últimas pesquisas vêm demonstrando que, os resíduos sólidos são um grande meio de transmissão do coronavírus e representa um risco para a população e para as pessoas que atuam diretamente nas coletas, tratamento e destinação final (ABRELPE, 2017). Para os governos em geral, o novo coronavírus representa um grande desafio, pois em menos de três meses o vírus se tornou um problema mundial e desafiou os sistemas de saúde dos países desenvolvidos e, principalmente dos países em processo de desenvolvimento.

Conceitualmente, de acordo com a Norma Brasileira Técnica (NBR) no 10004/2004 e Rodrigues, o subproduto proveniente de atividades humanas pode ser denominado de lixo ou resíduo. Ao primeiro termo designa-se aquilo que não pode ser reutilizado ou passar por um processo de transformação e ao segundo, o que pode retornar ao ciclo de produção, através de processos de transformação e voltam a ter valor econômico e de mercado. Além disso, a Política Nacional de Resíduos Sólidos (PNRS), Lei 12.305/2010, classifica os resíduos sólidos quanto à origem como resíduos domiciliares, de limpeza urbana, estabelecimentos comerciais e prestadores de serviços, industriais, de serviços de saúde, de 
construção civil, agrossilvipastoris, de transporte e de mineração e quanto à periculosidade como perigosos e não perigosos (Brasil, 2010).

Sabe-se que, o gerenciamento dos resíduos por parte dos municípios requer uma infraestrutura, além de processo de planejamento, manutenção, recursos técnicos e financeiros, visando dar efetividade a operação do sistema. Pesquisas apontam que no ano de 2017, 1.559 municípios apresentavam-se com disposições inadequadas de resíduos, isso ocorre por conta da destinação final em aterros sanitários que ainda não possui um perfil universal, e com isso $18 \%$ está sendo depositados em locais que não apresentam conformidade técnica e operacional, levando confronto com os ditames legais, que representam mais de 12 milhões de toneladas por ano (ABRELPE, 2017).

Em 2010 a Política de Resíduos Sólidos foi aprovada, e esta determinava que todos os lixões do país deveriam ter sido fechados até 2 de agosto de 2014 e o rejeito encaminhado para aterros sanitários. Contundo, não houve nenhuma mudança a partir de 2014, isso porque grande parte dos municípios brasileiros não conseguiram atingir esse objetivo necessário à liberação dos recursos para a implantação de Política Nacional de Resíduos Sólidos (PNRS). Com relação ao termo reciclagem, PNRS caracteriza como um processo de transformação das características físicas, físico-químicas ou biológicas dos resíduos sólidos, com o objetivo de gerar novos produtos ou insumos.

Assim, os municípios com população inferior a 50 mil habitantes foram os mais prejudicados, justamente pela falta de recursos e capacitação técnicas que não conseguiram cumprir as metas. Sendo assim, para tentar sanar tal problema, o prazo que não foi cumprido pela maior parte dos municípios pequenos, foi prorrogado por lei (SNIS, 2018).

No que se refere à coleta de resíduos domiciliares recicláveis, conforme dados do Sistema Nacional de Informações sobre Saneamento (SNIS), no ano de 2018, apenas $38,1 \%$ dos municípios participantes realizou algum tipo de coleta seletiva. Vale destacar que na região Nordeste neste mesmo ano, 63\% da coleta seletiva foi realizada por organizações de catadores (SNIS, 2018). A coleta seletiva é vista como o recolhimento antecipado dos resíduos, separados de acordo com sua constituição ou composição. Todavia, é preciso que os resíduos estejam 
previamente segregados e a coleta obedeça a algumas regras, como a separação do fluxo comum de coleta, para evitar possíveis contaminações e perdas de material.

Na perspectiva nacional, dados da ABRELPE (2018), apontam que dos 5.570 municípios brasileiros, apenas 4.070 possuem alguma iniciativa de coleta seletiva, 0 que representa $73,1 \%$ do total. No Nordeste, são 54,5\% dos municípios que tem alguma iniciativa, seja a coleta porta-a-porta, pontos de entrega voluntários (PEVs), ponto a ponto ou sistemas de troca. Com relação às taxas por material seco, segundo dados do SNIS (2017, p. 104), a quantidade de reciclagem foi de 26,3\% plástico; $12,4 \%$ metais; $11,2 \%$ vidro; $42,6 \%$ papel e papelão e $7,5 \%$ de outros materiais. Esses dados foram ainda afetados pela pandemia causada pela COVID-19, cujos primeiros casos foram notificados em dezembro de 2019, na cidade Wuhan, China, que impactou diretamente o trabalho desempenhado pelos catadores de material reciclável na coleta seletiva e no funcionamento de indústrias de reciclagem.

Assim, a quantidade de materiais reciclados já possui baixos índices no Brasil com apenas 3\% dos Resíduos Sólidos Urbanos (RSU) sendo reciclados, ao comparar a Alemanha que tem a maior taxa de reciclagem com $63 \%$ dos RSU reciclados, segundo estudos de Ibiapina (2019, p.68), o que mostra o tanto de trabalho e medidas que precisam ser implementadas para melhorar o índice e as dificuldades que esse setor vem passando nesse momento.

0 principal foco do trabalho é compreender quais os principais problemas enfrentados pela gestão dos resíduos sólidos no Brasil, levando em conta a situação atual em que estamos vivenciando, quais as soluções estão sendo tomadas tanto para amenizar a propagação do vírus como para diminuir os indicies de poluição ambiental e como essas medidas podem contribuir ou até mesmo servir de exemplo para outros municípios que passam pelo mesmo problema, e por fim deixar evidente para os leitores esse assunto que é de suma importância.

O presente trabalho teve como objetivo analisar a gestão dos resíduos sólidos urbanos durante a pandemia do COVID-19 e as medidas que vem sendo tomadas para a implantação da PNRS assim como compreender os problemas encontrados na gestão de resíduos sólidos. 


\section{METODOLOGIA}

Para construção deste trabalho, utilizou-se várias pesquisas bibliográficas (artigos científicos, livros), consideradas indispensáveis e de estrema importância para o tema em questão, com a finalidade de entender como ocorre a gestão dos resíduos sólidos no Brasil e as medidas que vem sendo tomadas para a implantação da PNRS assim como compreender os problemas encontrados na gestão de resíduos sólidos.

Em relação ao levantamento bibliográfico, o estudo é considerado como uma especialidade científica que busca ofertar as inovações e direcionamento das pesquisas (ELLEGAARD; WALLIN, 2015). E é necessário esse tipo de pesquisa para identificar as possíveis lacunas no estado do conhecimento, para que seja possível inovar, assegurar que não haja publicações idênticas e potencializar o conhecimento coletivo, que é difundido a partir de observações e citações dessas pesquisas, na elaboração de novos artigos (GOMES, 2016). As principais fontes utilizadas para a confecção desse artigo foram: Google Acadêmico, Scielo e Scopus.

A seguir serão expostos alguns pontos que são indispensáveis, para entender como está se dando a gestão dos resíduos sólidos e medidas que vem sendo tomadas para a implantação da PNRS.

\section{GESTÃO DOS RESÍDUOS SÓLIDOS E MEDIDAS QUE VEM SENDO TOMADAS PARA A IMPLANTAÇÃO DA PNRS}

\subsection{COVID -19 e Resíduos Sólidos}

O novo coronavírus, é chamado cientificamente de SARS-CoV-2, SARS é uma abreviação de uma síndrome chamada de Severe Acute Respiratory Syndrome, que traduzida significa Síndrome Respiratória Aguda Grave. É uma forma grave de muitas doenças respiratória, consequentemente seu principal sintoma é a dificuldade para respirar. CoV é a abreviação de coronavírus, que é a família a qual o vírus pertence, o número 2, é pelo motivo do vírus ser semelhante a uma outra espécie de coronavírus que quase virou uma pandemia em 2002, o SARS-CoV.

0 primeiro caso foi inicialmente observado em dezembro de 2019, na cidade de Wuhan, China. As pessoas infectadas pelo vírus tinham em comum o contato com 
o mercado de Wuhan, local que tem como cultura a comercialização e consumo de animais considerados exóticos para ocidentais. Os cientistas acreditam que as primeiras transmissões do vírus, foram através de animais, semelhante à forma de transmissão de 2003, que infectou humanos por meio de morcegos infectados.

Para evitar a propagação do vírus, países entraram em quarentena, maximizando o isolamento social, além de instruções para a população, como: higienizar as mãos com frequência, utilizando álcool em gel ou sabão e água, usar máscara quando não for possível manter o isolamento social, não tocar nos olhos, boca ou nariz, ao espirrar, cobrir o nariz com o braço dobrado ou um lenço para tossir, manter distância de pessoas com sintomas de tosse ou espirros e procurar atendimento médico caso apresente febre, tosse e dificuldade para respirar.

A produção de resíduos sólidos cresceu de forma significativa em meio a pandemia do novo coronavírus, principalmente com a obrigação do uso de máscara de proteção, que em grande parte são descartáveis, esses rejeitos, como máscaras, luvas e aventais descartáveis devem ser manipulados com muito cuidado, devido seu alto potencial de contaminação.

Luvas e máscaras, sejam descartáveis ou de panos, devem ser colocadas em sacolas plásticas bem amarradas0, antes de serem descartadas em lixo fechado. Outra recomendação é descartá-las no lixo do banheiro, considerado lixo comum e que, naturalmente, não atrai o interesse de catadores de recicláveis. o lixo doméstico de residências que possuem pessoas contaminadas ou com suspeita de contaminação pela COVID-19 deve ser descartado como lixo comum para não entrar na coleta seletiva para reciclagem. Em caso de confirmação ou suspeita da Covid-19 no local que irá descartar qualquer tipo de resíduo sólido, sugere-se os seguintes cuidados: Separar uma lixeira de uso exclusivo da pessoa infectada ou suspeita no cômodo reservado para ela; Colocar o saco de coleta inicial dentro de outro saco novo e limpo, fechar bem ambos com nó ou lacre; Uma pessoa não infectada deve retirar o saco do cesto pelo lado de fora e fechá-lo de forma que não vaze nem ar nem líquidos, para que o vírus fique dentro do saco de lixo; Identificar o saco ou compartimento de descarte com o aviso de "Covid-19. Pode estar contaminado"; imediata higienização das mãos com água e sabão e/ou álcool em gel 70\% após a manipulação dos resíduos, sacos e seus contêineres; higienizar pontos de contatos como alças e tampas de lixeiras. 


\subsection{POLÍTICA NACIONAL DE RESÍDUOS SÓLIDOS (PNRS)}

Política Nacional de Resíduos Sólidos (PNRS) integra poder público, iniciativa privada e sociedade civil. Em 2010, a Lei $n^{\circ} 12.305$ foi sancionada e a Política Nacional de Resíduos Sólidos foi instituída, regulamentada pelo decreto 7.404/10. A PNRS foi um marco no setor por tratar de todos os resíduos, como materiais que podem ser reciclados e reutilizados, sejam eles domésticos, industriais, eletroeletrônicos, entre outros, e também por tratar a respeito de rejeitos, que são materiais que não podem ser reaproveitados.

O constante aumento do consumismo nas cidades, proporciona um aumento na geração de resíduos sólidos urbanos. Esse crescimento de resíduos sólidos não é acompanhado do descarte adequado dos mesmos, o que se torna muito prejudicial para o meio ambiente e para a sanidade da população, grande parte dos resíduos sólidos desperdiçados poderiam ser reciclados ou até mesmo reutilizados. 0 gerenciamento dos resíduos sólidos vem sendo um obstáculo para as autoridades dos países e causando preocupações quanto à preservação do meio ambiente e a qualidade de vida das próximas gerações (ABDEL-SHAFY ET AL., 2018).

O Plano de Gerenciamento de Resíduos é uma metodologia de gerenciamento de resíduos baseado em planejamento, procedimentos e recursos que visam a redução da geração de resíduos, acondicionamento, coleta, tratamento e destinação dos resíduos (BRASIL, 2010). Os principais objetivos na PNRS são: 1. Proteção da saúde pública e da qualidade ambiental; 2. Não geração, redução, reutilização, reciclagem e tratamento dos resíduos sólidos; 3. Estimular à adoção de padrões sustentáveis de produção e consumo de bens e serviços; 4. Adoção, desenvolvimento e aprimoramento de tecnologias limpas como forma de minimizar impactos ambientais; 5. Redução do volume da periculosidade dos resíduos perigosos, entre outros.

\subsubsection{Destaques da Leí da Política Nacional de Resíduos Sólidos}

A PNRS agrupa uma serie de princípios, objetivos, instrumentos, diretrizes, metas e ações tomadas pelo Governo Federal, de forma isolada ou em sistema de cooperação com os Estados, Distrito Federal, Municípios ou particulares, com vista à gestão integrada e ao gerenciamento ambientalmente adequado dos resíduos sólidos (DOMINGOS; BOEIRA, 2015). 
Esta política destaca como fundamentais os princípios da Prevenção e Responsabilidade Compartilhada. O Princípio de Prevenção tem como finalidade intrínseca evitar o dano, na forma mais geral. Apenas quando não for possível evitar por completo o prejuízo ambiental, será aceito uma conduta redutora ou mitigadora do dano (MACHADO, 2012).

A lei $n^{\circ}$ 12.305/2010 define o princípio da responsabilidade compartilhada pelo ciclo de vida dos produtos, como: Conjunto de atribuições individualizadas e encadeadas dos fabricantes, importadores, distribuidores e comerciantes, dos consumidores e dos titulares dos serviços públicos de limpeza urbana e de manejo de resíduos sólidos, para reduzir os impactos causados à saúde humana e à qualidade ambiental decorrentes do ciclo de vida dos produtos (BRASIL, 2010, Art. 3º, XVII).

De acordo com Machado (2012) “o compartilhamento da responsabilidade previsto na Lei $n^{\circ} 12305 / 2010$ entrelaça pessoa física e jurídica de direito privado com pessoa jurídica de direito público. Esse elemento é fundamental para uma nova concepção na gestão e gerenciamento dos resíduos sólidos, porque trata-se da contribuição efetiva de todos atores da cadeia produtiva de resíduos os fabricantes, os importadores, os distribuidores, os comerciantes e os consumidores, na gestão deles, já que todos e sem distinção são afetados pelos impactos negativos dos resíduos (SILVA et al.,2020).

Dentro dos objetivos da lei n 12305/2010, o Artigo $7^{\circ}$ inciso I, aponta a "proteção da saúde pública e da qualidade ambiental" e traz orientações sobre a ordem de gestão e manejo dos resíduos sólidos, que entende-se como a "não geração, redução, reutilização, reciclagem e tratamento dos resíduos sólidos, bem como a disposição final ambientalmente adequada dos rejeitos" (Artigo $7^{\circ}$, inciso II), estão consideradas e são atitudes legalmente corretas na gestão dos resíduos sólidos, logo o descumprimento dessas obrigações coletivas promove a incidência de encargos financeiros aos poluidores (BRASIL, 2010).

Entre os destaques, a lei se dedica também ao âmbito social com reciclagem, fundamentado na participação formal dos catadores estruturados em cooperativas (SILVA et al., 2020). "São princípios da Política Nacional de Resíduos Sólidos: (...) integração dos catadores de materiais reutilizáveis e recicláveis nas ações que envolvam a responsabilidade compartilhada pelo ciclo de vida dos produtos" (BRASIL, 2010, cap. II, Art. 6º XII).

Pode-se considerar um outro grande avanço da lei, a necessidade da logística reversa. Indústrias, lojas, supermercados, distribuidores, importadores e comércio em geral necessitam praticar sistemas de logística reversa, a princípio para produtos como agrotóxicos, 
pilhas e baterias, pneus, óleos lubrificantes, lâmpadas, embalagens em geral e produtos eletroeletrônicos e seus componentes (BRASIL, 2010, cap. III, seção II, Art. 31, IV).

\subsubsection{A Problemática "Resíduos Sólidos" no Brasil}

A problemática dos Resíduos Sólidos no brasil passa ainda por grandes desafios, devido a gestão ambiental nos munícipios. Cada brasileiro gera, em média, $1 \mathrm{~kg}$ de resíduos sólidos urbanos por dia, a partir do que, estima-se que a população brasileira gera aproximadamente 71 milhões de toneladas de RSU por ano. Entretanto, apenas uma parte deste montante é destinado de forma ambientalmente adequada (BRASIL, 2010).

Segundo o Panorama de Resíduos Sólidos, elaborado pela ABRELPE (2018), no Brasil, em 2017, 40,9\% dos resíduos coletados foram despejados em locais inadequados por 3.352 municípios, totalizando mais de 29 milhões de toneladas de resíduos dispostos em lixões ou aterros controlados, que não possuem sistemas e medidas necessários à proteção do meio ambiente contra danos e degradações. Tais unidades ainda apresentam significativa presença em todas as regiões do país, recebendo mais de 80 mil toneladas de resíduos por dia, com um índice superior a $40 \%$ e um elevado potencial de poluição ambiental com geração de impactos negativos para o meio ambiente e a população.

\subsection{GESTÃO DE RESÍDUOS SÓLIDOS: o que são e como proceder} em tempos da COVID-19

O descarte de resíduo domiciliar e hospitalar, tem gerado uma série discussões desde a declaração da Organização Mundial da Saúde (OMS) sobre a pandemia do novo coronavírus, levando entidades de meio ambiente, governadores e prefeitos a tomarem certas medidas de cautela durante este período.

O descarte de resíduos domiciliares aumentou entre 15 a $25 \%$ já que as pessoas estão em isolamento social, segundo dados da Associação Brasileira de Empresas de Limpeza Pública e Resíduos Especiais (ABRELPE). Dados da ABRELPE apontam que a geração de resíduos hospitalares em unidades de atendimento à saúde aumentou de 10 a 20 vezes.

\subsubsection{Materiais Reutilizáveis ou Recicláveis}

Com o alto e aceleração crescimento da produção de resíduos sólidos, atitudes devem ser tomadas para driblar esses problemas, uma solução seria a 
reutilização ou reciclagem de resíduos sólidos, gerando sustentabilidade do meio ambiente e diminuição nas cadeias de consumo.

Os materiais recicláveis são aqueles que podem voltar a se tornar matériaprima, transformando-se em algo novo, ou seja, é utilizado um material para a criação de um novo material com uma utilidade distinta da que ele tinha anteriormente. Um exemplo de matéria reciclável são as garrafas PETs que podem se tornar fibras de poliéster, enquanto pneus velhos também podem ser transformados em composto de asfalto. Os materiais recicláveis mais presentes no nosso dia-a-dia são papel, metais, vidro, tecidos, plásticos e componentes de aparelhos eletrônicos. 0 processo de conversão desses materiais diminui o desperdício, além de reduzir o consumo de matérias-primas e energia.

Os materiais reutilizáveis em si, não possuem tanta diferença em relação aos materiais recicláveis. A reutilização parte do princípio que, um material usado, não necessariamente é lixo. 0 reprocessamento é dispensado e o item pode ser usado como um novo produto, adquirindo funções diferentes, sem perder suas principais características. A ideia da reutilização é evitar o desperdício e ser criativo. As possibilidades são variadas para um mesmo material.

Papeis podem se tornar decoração em artesanatos ou bloco de anotações para rascunho. Uma lata, ao ser decorada, pode voltar a ter utilidade como um cofre ou uma porta objetos. A reutilização não contribui tanto para o direcionamento dos resíduos, como a reciclagem. Ao olhar por outro angulo, é possível perceber que a reutilização influência na gestão do lixo, que não será descartado de qualquer forma em lixões.

\subsubsection{Resíduos Orgânicos}

Lixo orgânico é um material de origem biológica, pode ser proveniente da vida animal ou vegetal. Os restos de verduras, frutas e outros alimentos causam dúvidas na hora do descarte. A compostagem é a maneira mais sustentável de fazer a reciclagem do lixo orgânico, a vantagem da compostagem é que é plenamente possível realizá-la em casa, até mesmo em apartamento. A vermicompostagem, feita a partir de uma composteira doméstica utilizando minhocas, resolve o problema do lixo orgânico, proporciona húmus e biofertilizante líquido (se cada parte de chorume for diluída em dez partes de água) que também funciona como pesticida natural. 
Há diversos modelos de composteiras disponíveis. A alternativa mais utilizada nos centros urbanos para fazer a reciclagem do lixo orgânico é a composteira convencional, formada por três ou mais caixas empilháveis de plástico. A quantidade de caixas e a dimensão das mesmas depende da quantidade dos resíduos orgânicos produzidos pela população. 0 sistema de caixas funciona da seguinte forma: As duas primeiras caixas, que ficam no topo, são digestoras e possuem furos no fundo, onde ocorre a decomposição através de minhocas, os furos são úteis para escoamento de líquidos, a caixa abaixo das digestoras é a caixa coletora, que serve para armazenar o chorume produzido no processo.

\subsubsection{Equipamentos de Proteção Individual (EPI): Máscaras, luvas e aventais descartáveis}

Com a situação de pandemia, foi intensificado o uso de EPI's no âmbito doméstico e hospitalar, que evitam não somente o coronavírus, como quaisquer outros possíveis problemas de saúde em um momento em que os cuidados hospitalares não estão fáceis. As instalações de gerenciamento de resíduos sólidos, serviços de reciclagem, tratamento e disposição não podem interromper as atividades, tendo em vista que é um serviço fundamental para garantir condições básicas de saneamento e a manipulação desses materiais se torna um serviço urgente e essencial em tempo de pandemia. É necessário garantir que os resíduos domiciliares e infecciosos coletados sejam tratados e descartados com segurança, assegurando que sejam planejadas e implantadas ações contra riscos à saúde pública.

No Brasil, a responsabilidade das prefeituras abrange a gestão de resíduos sólidos e limpeza pública convencional; Intensificar a higienização e uso dos EPIs; Elaborar plano de contratação e treinamento de temporários; Afastar das atividades os empregados dos grupos de risco ou que tenham sintomas do Covid-19; A coleta dos recicláveis ainda é uma questão de debate, mas para os_profissionais que paralisarem suas atividades, sugerem auxílio social temporário. Já a responsabilidade social inclui colocar os resíduos em 2 sacos vermelhos, limpos, resistentes e descartáveis; fechar com lacre ou nó quando tiver 2/3 (dois terços) de sua capacidade; Se possível, identificar a sacola; Descartar normalmente para a coleta de resíduos urbanos (ARAÚJO E SILVA, 2020). 
3.3.4. Como descartar os resíduos de locais com casos da Covid19

Infectologistas do país, ressaltam a necessidade de pessoas infectadas ou com suspeita de infecção pelo vírus, terem mais cuidados no momento do descarte de resíduos sólidos, como, por exemplo, ter uma lixeira de uso exclusivo para a pessoa contaminada, usar sacos de lixo reforçados e que possam ser vedados, manuseá-los com luvas a serem descartadas posteriormente e higienizar as alças e as tampas das lixeiras frequentemente.

Nos domicílios em que houver morador(es) com confirmação ou suspeita de contaminação por COVID-19, os resíduos produzidos pelo paciente devem ser colocados em sacos plásticos resistentes e devidamente lacrados. Em seguida devem ser colocados dentro de um segundo saco plástico que também deverá ser devidamente fechado, e posteriormente apresentado para coleta regular de limpeza urbana (resíduos comuns).

Deve ser terminantemente proibido pelos departamentos de limpeza urbana o descarte de tais resíduos para coleta seletiva, ou seu depósito em contentores destinados para fração seca (recicláveis), bem como seu abandono em vias públicas.

A gestão dos resíduos sólidos contaminados ou com suspeita de contaminação por COVID-19 gerados em unidades de atendimento à saúde ou locais com grande concentração de pessoas infectadas (hotéis, navios, aeroportos etc.) deve seguir a regulamentação aplicável aos resíduos infectantes do Grupo A1, conforme Resoluções CONAMA 358/2005 e ANVISA RDC 222/2018, lembrando que tais resíduos requerem gerenciamento diferenciado dos resíduos comuns e tratamento prévio à sua disposição final.

\subsection{Desmaterialização no gerenciamento de resíduos sólidos e} Impactos ambientais dos resíduos sólidos durante a pandemia

Esse tema gira em torno do desenvolvimento econômico sustentável, buscando mudanças tanto para extração de recursos, quanto à destinação dos resíduos gerados pela economia (Van Ewjik; Stegmann, 2016), assim como reduzir o uso de materiais primários principalmente, com intuito de reciclar e reutilizar, gerando um ciclo de melhor aproveitamento. 
Os países sul americanos ainda enfrentam vários desafios na gestão de resíduos sólidos que demanda atenção especial, conforme a presença de lixões a céu aberto (33\%) ou baixas taxas de recuperação de resíduos recicláveis (menos de 4\%) (MARGALLO et al., 2019). Muitos países em desenvolvimento não realizam um manejo sustentável de resíduos sólidos, o que os tornam mais suscetíveis à possibilidade de propagação do Corona vírus por conta de práticas inadequadas para o gerenciamento destes, já que os efeitos da pandemia a COVID- 19 em relação aos sistemas de gestão de resíduos sólidos, estão em processo de estudos científicos (Zand; Heir, 2020). De acordo com estes autores os problemas ambientais e de saúde podem piorar, se os materiais descartados, incluindo EPI's contaminados não forem gerenciados corretamente, e nos países em desenvolvimento esses riscos são bem maiores, considerando que possuem estratégias ineficientes de gestão de resíduos.

Alguns países e municípios usam tratamentos alternativos para seus Resíduos de Serviço de Saúde (RSS), sendo as principais formas de tratamento dos RSS as autoclaves e incineradores, com destino final a aterros sanitários, outros com menos recursos econômicos podem destinar a processos não licenciados ambientalmente e colaborar com os efeitos negativos ao meio ambiente, à saúde humana e a segurança (SILVA et al., 2020; ISWA, 2020). Os impactos ambientais produzidos em relação ao gerenciamento dos resíduos sólidos, se deve principalmente ao grande uso de produtos plásticos descartáveis e de EPI.

\subsection{Consequências em não realizar o gerenciamento de} resíduos e vantagens em fazer a correta gestão de resíduos

Diversos problemas, desde o momento da coleta o trabalhador pode se contaminar ou se machucar com resíduos perigosos. Considerando o descarte incorreto em lixões, que se tornam ambientes favoráveis a incidência de vetores e doenças, a contaminação do solo que acontece mesmo nos aterros sanitários, e as pessoas que catam e/ou reciclam os materiais que chegam aos lixões ou aterros estão sujeitas a riscos de saúde.

É questão de saneamento básico, o ideal é desde o descarte correto e seletivo, assim como a coleta e a destinação para pontos de reciclagem e tratamento. É vantajoso pois se tem um racionamento dos resíduos descartados, em vez de terem uma disposição final que só vai trazer problemas, quando se pode e deve minimizar os impactos ambientais, sanitários, sociais. 


\subsection{Responsabilidade da sociedade}

Nós enquanto cidadãos nessa situação de pandemia devemos exercer nossa compreensão e nos responsabilizar para evitar a disseminação do coronavírus, inclusive a nossa conduta diante dos nossos resíduos. Esse cuidado proporciona diferença especialmente quando aplicado nos setores de geração ou manipulação de grandes volumes de resíduos, como estabelecimentos e cooperativas de reciclagem.

Mas também se torna necessário que o governo garanta uma comunicação clara para que os cidadãos fiquem sabidos da importância sobre a segregação dos resíduos perigosos de não perigosos, diretamente na fonte de origem e nos pontos de geração, através de campanhas públicas ou vídeos em plataformas digitais (HAQUE et al., 2020).

\subsubsection{Empresas, Estabelecimentos e Condomínios}

Tem fundamental importância para reprimir a disseminação da doença a adoção de medidas para divisão segura dos resíduos sólidos domiciliares, assim como a adequação das instalações de quarentena, dos hospitais e a gestão institucional do setor (OYEDOTUN et al. 2020). É recomendado a aplicação de solução desinfetante aos resíduos recicláveis e armazenamento destes por 72 horas, antes de iniciar a triagem ou encaminhar para reciclagem, pois a falta deste manejo torna os catadores e cooperados mais suscetíveis a contaminação pelo vírus (ORIS, 2020).

Se tem como recomendações adequadas a empresas e estabelecimentos com trânsito de público e grupo de colaboradores e condomínios: Instruir seus colaboradores e/ou usuários sobre as medidas sanitárias vigentes e como proceder com relação aos resíduos sólidos; Disponibilizar locais para a higienização das mãos com água corrente, sabão e/ou dispensers com álcool em gel 70\% a todos e intensificar, durante o expediente, o ato de higienizar as mãos; Ampliar a regularidade e cautela com a higienização de superfícies de contato de seus postos de trabalho como mesas, bancadas, máquinas, equipamentos eletrônicos e ferramentas, e áreas de uso comum com solução de Hipoclorito de Sódio diluído (consultar as instruções da embalagem do produto) ou álcool acima de 70\%, essa atitude evita o contágio e a contaminação de objetos e materiais que serão por fim descartados; Uso e descarte corretos de EPIs, priorizando pôr em sacos plásticos 
individuais e só depois descartá-los em lixeiras de rejeito; Resíduos produzidos por clientes, público e transeuntes devem ser vistos como contaminados, ainda que não apresentem qualquer sintoma. Manejar e lacrar adequadamente seus compartimentos usando máscaras e luvas, pôr o saco de coleta dentro de outro novo e limpo, desinfetar os sacos e seus contêineres com solução diluída de Hipoclorito de Sódio (consultar as instruções da embalagem do produto) ou álcool líquido acima de 70\% e fechar bem com nó ou lacre; A seguir a manipulação de resíduos, sacos e seus compartimentos deve-se dispor o EPI usado no procedimento em um saco individual e descartar em lixeira de rejeitos e desinfetar as mãos cuidadosamente com água e sabão e/ou álcool em gel $70 \%$ os frequentadores, transeuntes e colaboradores; Acomodar nas ruas os sacos e contêineres somente nos dias e horários que ocorre a coleta pelo seu bairro, evitando que esse material contamine o local ou fique acessível a animais e transeuntes desavisados de seu potencial de contaminação; Resíduos recicláveis neste período de pandemia, recomenda-se descartar junto ao rejeito, destinando-os à coleta do "lixo comum".

Contudo, na ocasião de grandes volumes e optando por reciclá-los, tomar os devidos cuidados higienizando e desinfetando os itens e seus contêineres, se viável isolá-los por até $72 \mathrm{~h}$ em local seco antes de destiná-los à coleta seletiva, logística reversa ou cooperativa de reciclagem; Ocorrendo suspeita ou confirmação da Covid19 entre residentes e frequentadores de condomínios, todos as cautelas com os resíduos, juntamente a condutas individuais e de dever das administradoras desses condomínios devem ser levadas em consideração; Treinar todos os colaboradores com relação a correta execução das medidas acima citadas; Verificar as legislações atuais de descarte de resíduos, federal, estadual e municipal (SÃO PAULO, 2020).

\subsubsection{Cooperativas e Catadores de recicláveis}

0 manuseio dos objetos destinados à reciclagem tem apresentado alta demanda, e é necessário que todas as pessoas incluídas no processo adotem medidas de precaução e higiene redobradas ao longo da pandemia da Covid-19. Como citado antes, a sobrevida do corona vírus em superfícies como metal, vidro, papel e plástico é de até 72 horas, estes itens são os de maior volume entre os recicláveis descartados, o que contribui para o contágio de toda a rede e pessoas envolvidas no processo. Segue algumas providencias específicas para esse setor, 
muito importante para o rumo correto dos resíduos, e que não pode parar de funcionar mesmo perante a pandemia:

Todos envolvidos no processo, a partir da coleta e a divisão à destinação, devem ter acesso aos EPIs eficientes como máscaras e luvas, em quantidade necessária para suas trocas e reposições corretas; Devem ser capacitados conforme o correto uso e descarte de EPIs, dispor em sacos plásticos individuais e só depois descartá-los em lixeiras de rejeito; Água e sabão ou álcool em gel 70\% ao alcance para frequente higienização e descontaminação das mãos; Conter de forma rigorosa o contato das mãos com o rosto, boca, nariz e olhos, locais de entrada do vírus no organismo; Aos colaboradores e/ou cooperados com idade igual ou superior a 60 (sessenta) anos, gestantes, lactantes ou portadores de doenças crônicas, recomenda-se o desligamento temporário de suas atividades de forma remunerada, durante a vigência de decreto enunciado pela prefeitura atendendo a situação de pandemia da Covid-19; A segregação dos recicláveis deve ser realizada em locais arejados e controlados com distanciamento entre indivíduos de no mínimo 1,5m e/ou 1 pessoa a cada $15 \mathrm{~m}^{2}$. Em situações que o espaço físico não comporta ou permite esse distanciamento, reorganização de turnos; No contexto de recepção de saco ou caixa apropriadamente identificada como resíduo oriundo de local com situação suspeita ou confirmado da Covid-19, adotar cuidados de proteção (uso de EPI) e higienização das mãos redobrado. Sempre que possível, manter o conteúdo isolado em local seco por até 72 horas antes de maneja-lo na divisão e encaminhamento do conteúdo; Correta capacitação e acessibilidade a esses conhecimentos a todos os envolvidos no processo, colaboradores e/ou cooperados; Acompanhar as orientações e exemplos das associações, movimentos e de outras cooperativas que já aplicam precauções para com os seus cooperados (SÃO PAULO, 2020).

\section{CONSIDERAÇÕES FINAIS}

A partir da realização de levantamento de informações nota-se que a Covid-19 exemplificou a necessidade de revisão urgente de procedimentos para garantir a segurança dos trabalhadores e manter a qualidade dos serviços essenciais na área da saúde e, sobretudo, de coleta de resíduos sólidos. Por fim, todo esse processo deve ser visto com otimismo e com a possibilidade de novas maneiras, mais eficientes, sustentáveis e limpas de saneamento 
do resíduo sólido urbano surgirem e se disseminarem, assim como novas maneiras de interações humanas e valorização do que realmente tem importância na vida.

\section{REFERÊNCIAS}

ASSOCIAÇÃO BRASILEIRA DE EMPRESAS DE LIMPEZA PÚBLICA E RESÍDUOS ESPECIAIS (ABRELPE). Panorama dos Resíduos Sólidos no Brasil, 2017. Disponível em: http://abrelpe.org.br/panorama/. Acesso em: 29 de junho de 2021.

ARAÚJO, Elaine Cristina dos Santos et al. A gestão de resíduos sólidos em época de pandemia do Covid-19. 2020.

ABNT. NBR 10004 - Classificação de Resíduos Sólidos. Rio de Janeiro, 2004.

BRASIL. Política Nacional dos Resíduos Sólidos. Lei n 12.305, 2010.

HAQUE, M. S.; UDDIN, S.; SAYEM, S. M.; MOHIB, K. M. Coronavirus disease 2019 (COVID-19) induced waste scenario: A short overview. Journal of Environmental Chemical Engineering, p. 104660, 2020.

International Solid Waste Association (ISWA). La Gestión de los Residuos durante la pandemia COVID-19 -Recomendaciones de ISWA. Países Baixos, Versión 8, abr.2020.

VAN EWIJK, Steven; STEGEMANN, J. A. Limitations of the waste hierarchy for achieving

absolute reductions in material throughput. Journal of Cleaner Production, v. 132, p. 122-128, 2016.

MARGALLO, M.; ZIEGLER-RODRIGUEZ, K. ; VÁZQUEZ-ROWE, I.; ALDACO, R.; IRABIEN, Á. ; KAHHAT, R. Enhancing waste management strategies in Latin America under a holistic environmental assessment perspective: A review for policy support. Science of the Total Environment, v. 689, p. 1255-1275, 2019.

RAUBER, M. E. 2011. Apontamentos sobre a Política Nacional de Resíduos Sólidos, instituída pela Lei Federal 12.305, de 02/08/2010. Revista Eletrônica Gestão, Educação e Tecnologia Ambiental. v.4, n.4. Disponível em: http://cascavel.ufsm.br/revistas/ojs2.2.2/index.php/reget/article/view/3 893/2266 Acesso em: 29 de junho de 2021

SILVA, A. L. P.; PRATA, J. C.; WALKER, T. R.; DUARTE, A. C.; OUYANG, W.; BARCELÒE, D.; ROCHA-SANTOS, T. Increased plastic pollution due to COVID-19 pandemic: Challenges and recommendations. Chemical Engineering Journal, p._126683, 2020.

SNIS. Diagnóstico do Manejo de Resíduos Sólidos Urbanos 2018. Brasília. Versão republicada 2019. 
ZAND, Ali Daryabeigi; HEIR, Azar Vaezi. Emerging challenges in urban waste management in Tehran, Iran during the COVID-19 pandemic. Resources, Conservation, and Recycling, v. 162, p. 105051, 2020.

OYEDOTUN, T.D.; KASIM, O. F.; FAMEWO, A. ; OYEDOTUN,T. D.; MOONSAMMY, S. ; ALLY, N. ; REEN-MOONSAMMY, D. Municipal waste Management in the era of COVID-19: Perceptions, Practices, and Potentials for Research in Developing Countries. Research in Globalization, v. 2, p. 100033, 2020 


\section{SOBRE OS ORGANIZADORES}

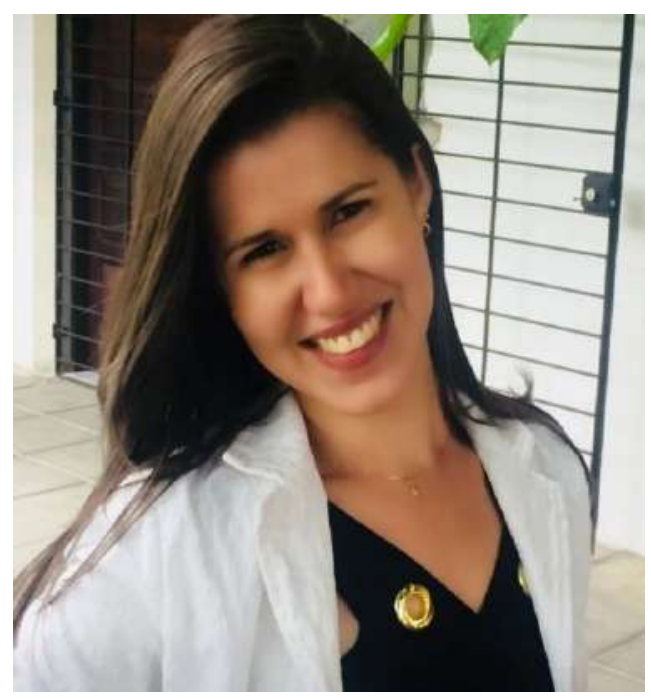

\section{MARIA JOSÉ DE HOLANDA LEITE}

Doutora em Ciências Florestais pelo Programa de Pósgraduação em Ciências Florestais (PPGCF) da Universidade Federal Rural de Pernambuco (UFRPE) (2018). Mestre em Ciências Florestais pelo Programa de Pós-graduação em Ciências Florestais (PPGCF) da Universidade Federal de Campina Grande (UFCG) (2014) e Engenheira Florestal pela Universidade Federal de Campina Grande (UFCG) (2012). Especialista em Engenharia de Segurança do Trabalho, pela Faculdade Integradas de Patos (FIP) (2017) e Técnica de Saúde e Segurança do Trabalho, pela Escola técnica Redentorista (ETER) (2007). Presentemente é Professora substituta da Universidade Estadual do Maranhão e Professora voluntária na Universidade Federal de Alagoas (UFAL). Com experiência nas áreas de Segurança do Trabalho e Ecologia e Conservação dos Recursos Florestais e Engenharia Florestal, com enfase em: Ecologia Funcional de Plantas (aspectos morfológicos e fisiológicos), Silvicultura, Recuperação e Manejo de Áreas Degradadas, Produção e Fertilização de Mudas Florestais, Licenciamento Ambiental, Análise e Avaliação de Impactos Ambientais, Educação Ambiental e Engenharia de Segurança do Trabalho.

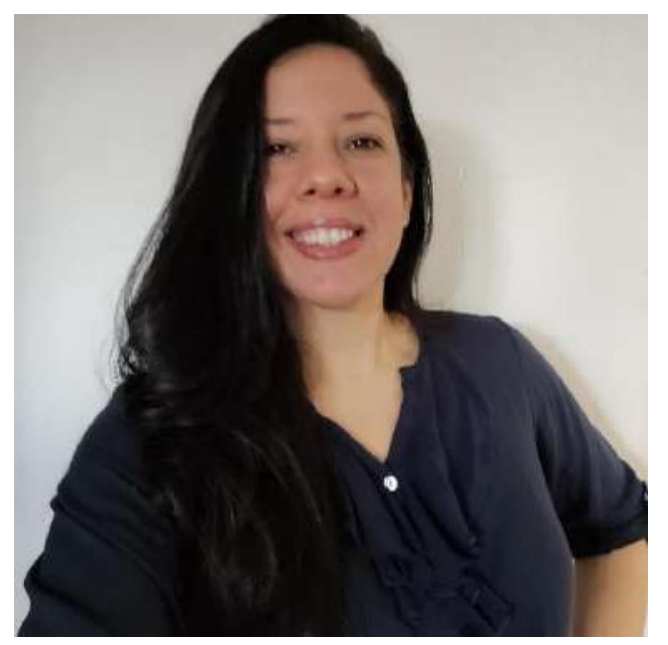

\section{ANDRÉA DE VASCONCELOS FREITAS PINTO}

Concluiu a graduação em Engenharia Florestal pela Universidade Federal Rural de Pernambuco (UFRPE) em 2008, onde participou ao longo de sua graduação do Programa de Educação Tutorial do curso de Engenharia Florestal, estando sempre engajada em atividades de Ensino, Pesquisa e Extensão. No ano de 2011 tornou-se Mestre em Ciências Florestais - UFRPE. Em 2015 tornouse Doutora pelo Programa de Pós- Graduação em Ciências Florestais na UFRPE. Atualmente é vice-coordenadora do Programa de Pós-Graduação stricto sensu em Energia da Biomassa e professora Adjunta da graduação na Universidade Federal de Alagoas (UFAL), Centro de Ciências Agrárias (CECA), Rio Largo-AL. Tem experiência na área de Segurança do Trabalho, Recursos Florestais e Engenharia Florestal, com ênfase em Silvicultura e Conservação de Recursos Florestais (Viveiros Florestais, Restauração Florestal, Levantamentos Fitossociológicos, Polinização, Dispersão e Diversidade Funcional). 


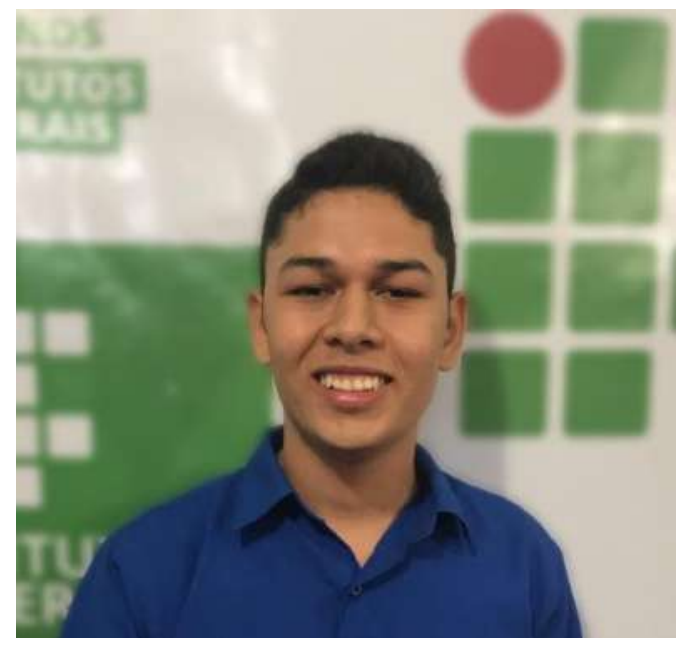

\section{LUIS ALBERTO ROCHA RODRIGUES JUNIOR}

Possui formação técnica em Informática pelo Instituto Federal de Ciência e Tecnologia do Maranhão - IFMA (2018). Foi bolsista de iniciação científica pelo Instituto Federal de Ciência e Tecnologia do Maranhão com título desenvolvimento de software para controle de custo no sistema de produção de peixes, orientado pelo professor Lucas Fernandes da Silva (2017). Foi bolsista de iniciação científica PIBIC/UEMA pela Universidade Estadual do Maranhão no projeto de título caracterização, propagação e conservação de fruteiras nativas da baixada maranhense, orientado pelo Professor Doutor José Ribamar Gusmão Araujo (2019). Atualmente é bolsista voluntario no projeto de pesquisa intitulado inserção da meliponicultura como estratégia no desenvolvimento local em santo amaro do maranhão - MA orientado pelo professor Dr. José Ribamar Silva Barros. Graduando em Agronomia na Universidade Estadual do Maranhão (UEMA) - Campus São Luís. 


\section{LEGISLAÇĀO NA AGRONOMIA: RESPONSABILIDADE SOCIAL PARA UM FUTURO MELHOR}

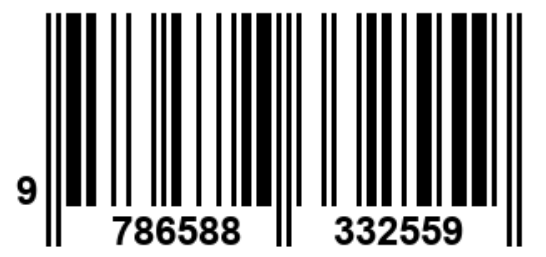

